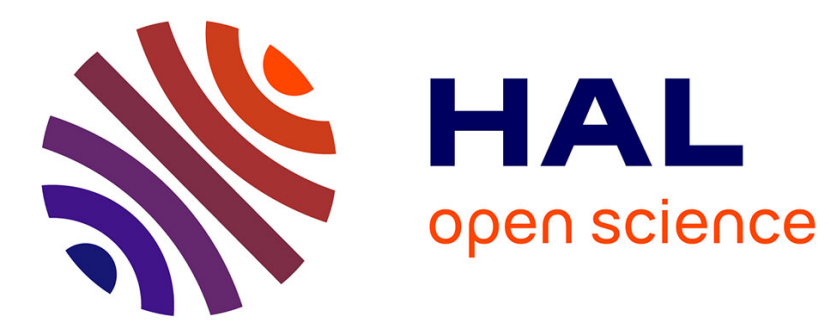

\title{
The Role of Redox Processes in Determining the Iron Isotope Compositions of Minerals, Melts, and Fluids
} Paolo A Sossi, Baptiste Debret

\section{To cite this version:}

Paolo A Sossi, Baptiste Debret. The Role of Redox Processes in Determining the Iron Isotope Compositions of Minerals, Melts, and Fluids. Magma Redox Geochemistry, 2021, 978-1-119-47325-1. hal-03368395

\section{HAL Id: hal-03368395 \\ https://hal.science/hal-03368395}

Submitted on 20 Oct 2021

HAL is a multi-disciplinary open access archive for the deposit and dissemination of scientific research documents, whether they are published or not. The documents may come from teaching and research institutions in France or abroad, or from public or private research centers.
L'archive ouverte pluridisciplinaire HAL, est destinée au dépôt et à la diffusion de documents scientifiques de niveau recherche, publiés ou non, émanant des établissements d'enseignement et de recherche français ou étrangers, des laboratoires publics ou privés. 


\section{The role of redox processes in determining the iron isotope compositions of} minerals, melts and fluids

3 Paolo A. Sossi ${ }^{1,2}$ and Baptiste Debret ${ }^{1,3}$

$4 \quad{ }^{1}$ Institut de Physique du Globe de Paris, Université de Paris, 1 rue Jussieu, 75005, Paris, France

$5{ }^{2}$ Institute of Geochemistry and Petrology, ETH Zürich, Sonneggstrasse 5, CH-8092, Zürich,

6 Switzerland

$7 \quad{ }^{3}$ Laboratoire G-Time, DGES, Université Libre de Bruxelles, ULB, CP 160/02, 1050 Brussels,

8 Belgium

9 Abstract

10 Stable isotope fractionation is a response to the minimisation of free energy associated with differences

11 in vibrational frequencies during substitution of isotopic masses between two phases. Site properties

12 are dictated by the bonding environment of iron, and influence its 'force constant', a descriptor for bond

13 strength. Because iron readily transitions between its ferrous $\left(\mathrm{Fe}^{2+}\right)$ and ferric $\left(\mathrm{Fe}^{3+}\right)$ state over the

14 oxygen fugacities $\left(f \mathrm{O}_{2}\right)$ of terrestrial magmas, redox processes are presumed to control iron isotope

15 fractionation. In fact, both co-ordination and redox state are key to interpreting iron isotope variations

16 in high-temperature, high-pressure geological systems. Determinations of iron force constants by

17 experimental, theoretical and spectroscopic means in minerals, melts and fluids are reviewed,

18 emphasising the effect of composition in influencing isotopic fractionation. Within this framework, the

19 application of numerical models of partial melting to iron isotope variations in oceanic basalts and

20 subduction-zone (or arc) magmas has shed light on their genesis. The influence of melt composition,

21 mineral mode and fluid exsolution in producing iron isotope fractionation in evolving magmas is

22 explored. Iron isotopic signatures in magmatic rocks are linked to that of their sources, and are

23 influenced by the iron isotopic evolution of subducting slabs and transfer of fluids to the mantle wedge. 


\section{Introduction}

The existence of iron in three predominant oxidation states in high temperature processes $\left(\mathrm{Fe}^{0}, \mathrm{Fe}^{2+}\right.$, $\mathrm{Fe}^{3+}$ ) provides considerable scope for the fractionation of its isotopes. This property, together with the fact that iron is the often most abundant polyvalent element in natural systems, has made its isotopic composition the most well-studied of the non-traditional systems (see Dauphas et al. 2017 for a recent comprehensive review).

Owing to the role that iron plays in determining the oxygen fugacity $\left(f \mathrm{O}_{2}\right)$ of a geological system, variations in its isotopic composition have often been ascribed to changes in its redox state (e.g., Williams et al. 2004; Dauphas et al. 2009). This approach comes at the expense of consideration of the co-ordination of iron, which can have an equally important role in engendering isotopic fractionation (see Young et al. 2015; Sossi and O'Neill, 2017). Furthermore, the oxygen fugacity of a system may have an indirect effect on the iron isotope composition by modifying the stability of different phases and solid solutions (e.g., the precipitation of pyrite from hydrothermal fluids, Wawryk and Foden 2015; or the composition of spinels in solid solution series, Roskosz et al. 2015). Sossi et al. (2016) and Fujii et al. (2014) emphasised the role of co-ordinating ligand field strength (e.g., $-\mathrm{S},-\mathrm{Cl}$, and $-\mathrm{OH}$ ) in affecting iron isotopic fractionation in minerals and fluids, respectively, by way of changing bond covalence and hence bond stiffness (Hill et al. 2010). Although this effect is limited in terrestrial mafic magmas in which iron is almost exclusively co-ordinated by oxygen, it becomes an important consideration in intermediate- and silicic magmas that can exsolve hydrothermal fluids (see Heimann et al. 2008) and in fluid-loss during mineral breakdown and subsequent dehydration of subducting slabs (see Debret and Sverjensky, 2017).

Deconvolving these controls is not straightforward because they tend to be intertwined; for example, simply varying temperature will affect the relative stability of minerals that precipitate from a fluid and these differing assemblages would be reflective of a different $f \mathrm{O}_{2}$. Similarly, because the $\mathrm{Fe}^{3+}$ cation has an ionic radius smaller than that of its ferrous counterpart, it prefers to partition into smaller, tetrahedrally-co-ordinated sites, whereas $\mathrm{Fe}^{2+}$ has a greater preference for octahedral sites in melts and minerals (e.g., Wilke 2005). As such, these compounding effects on the magnitude of stable isotope fractionation require careful theoretical (e.g., Schauble et al. 2001), experimental (e.g., Shahar et al. 2008) and spectroscopic (e.g., Dauphas et al. 2012) approaches in order to tease out the individual contribution of each.

Rather than tackling iron isotopic variation in natural systems by an inverse approach (i.e., through sample measurement and interpretation), in this review, the role of iron oxidation state and coordination number in controlling iron isotope fractionation is critically examined from a first-principles perspective (section 2.0.). In order to do so, the methods by which equilibrium iron isotope fractionation factors can be determined, and a compilation of existing data are briefly reviewed (section 3.0.). A 
59

60

61

general introduction to the ways in which iron isotope fractionation between minerals, melts and fluids depend on redox processes is presented in section 4.0. Finally, how these determinations have been applied to interpret variation in natural systems, comprising partial melting, magmatic differentiation and fluid transfer in the crust and mantle is detailed (section 5.0.).

\subsection{Principles and nomenclature}

Ratios of two isotopes, $n$ and $d$ of an element, $E$, are generally expressed relative to their ratio in a standard in delta notation, which is given by:

$$
\delta^{n / d} E=\left(\frac{\left({ }^{n} E /{ }^{d} E\right)_{\text {sample }}}{\left({ }^{n} E / /^{d} E\right)_{\text {standard }}}-1\right) \times 1000
$$

The fractionation factor between two phases $A$ and $B$ is:

$$
\Delta^{n / d} E_{A-B}=\delta^{n / d} E_{A}-\delta^{n / d} E_{B}
$$

and is related to alpha notation by the equivalence:

$$
\Delta^{n / d} E_{A-B}=10^{3} \ln ^{n / d} \alpha_{A-B}(3)
$$

The exchange of isotopes between two phases, $A$ and $B$, can be written:

$$
{ }^{d} E_{A}+{ }^{n} E_{B}={ }^{d} E_{B}+{ }^{n} E_{A \cdot}(4)
$$

The equilibrium distribution of isotopes between the two phases is described by the fractionation factor, $\alpha:$

$$
\alpha^{\frac{n}{d}} E_{A-B}=\frac{\left({ }^{n} E /{ }^{d} E\right)_{A}}{\left({ }^{n} E /{ }^{d} E\right)_{B}} \cdot(5)
$$

When the $B$ phase consists of solely dissociated atoms of element $E$ (as in an ideal, monatomic gas), the fractionation factor is given the name beta factor (or $\beta$ factor) and represents a convenient way of normalising fractionation factors to a ' 0 ' value (as there is no energy associated with isotopic substitution in a dissociated monatomic element, $E^{0}$ ). For cases in which the stoichiometric coefficients are unity, equation (5) is equivalent to an equilibrium constant. Therefore, the free energy of the isotopic substitution at equilibrium can be described:

$$
\Delta G_{(5)}^{o}=-R T \ln \left(\alpha^{\frac{n}{d}} E_{A-B}\right) \cdot(6)
$$

At the conditions (temperature, $T$; pressure, $P$ ) relevant to magmatic processes, classical thermodynamic terms cancel and isotopic fractionation is broadly onset by differences in the energy associated with vibrational frequencies in molecules and in condensed phases among one another. In the harmonic approximation, these vibrational energies $\left(E_{v i b, i}\right)$ are quantised into $n$ equally-spaced 
levels, where the finite minimum half quantum of energy that arises from the uncertainty in the positions and momenta that a particle, $i$, could occupy in its ground state $(n=0)$, corresponds to the 'zero-point' energy:

$$
E_{v i b, i}=\left(n_{i}+\frac{1}{2}\right) h v_{i \cdot}(7)
$$

Here, $h$ is Planck's constant and $v_{i}$ is the vibrational frequency. Because, even at $1000 \mathrm{~K}$, as given by the Boltzmann equation, particles occupy vanishingly small amounts of their excited states $(n>0)$, the differences in vibrational frequencies between two isotopes is solely controlled by differences in zeropoint energies. For changes in pressure, the relationship between the mode Gruneisen parameter $\left(\gamma_{\mathrm{G}, \mathrm{i}}\right)$, the vibrational frequency and molar volume $(V)$ at constant temperature in the quasi-harmonic approximation (Polyakov and Kharlashina 1994), leads to a predictable increase in frequency with pressure due to contracting molar volumes:

$$
\left(\frac{\partial \ln v_{i}}{\partial \ln V}\right)=-\gamma_{G, i}
$$

As volume changes induced by isotopic substitutions are typically small, correspondingly large pressure variations are required to significantly influence isotopic fractionation. Frequencies for a simple diatomic molecule (or, approximately, a mean completely symmetric case) are given by:

$$
v_{i}=\frac{1}{2 \pi} \sqrt{\frac{K}{\mu}},(9)
$$

Where $K$ is the force constant of vibration and $\mu$ the reduced mass. The derivation of the dependence of isotopic fractionation on the vibrational frequencies of molecules was first expressed by Urey (1947) and Bigeleisen and Mayer (1947) in the harmonic approximation in terms of the vibrational isotopic partition function:

$$
Q_{v i b, i}=\prod_{i} \frac{e^{\left(-\frac{h v_{i}}{2 k T}\right)}}{1-e^{\left(-\frac{h v_{i}}{k T}\right)}} \cdot(10)
$$

Equation (10) is the product across all vibrational frequencies $v_{i}$ for a given isotope in a given phase, where $k$ is Boltzmann's constant and $T$ absolute temperature. Ratios of vibrational partition functions may be equated to fractionation factors in a simplified manner (Urey 1947; Bigeleisen and Mayer 1947):

$$
10^{3} \ln \alpha^{\frac{n}{\bar{d}}} E_{A-B}=\Delta^{\frac{n}{\bar{d}}} E_{A-B}=\frac{10^{3} 3 N}{96}\left(\frac{h}{\pi k T}\right)^{2}\left(\frac{1}{m_{d}}-\frac{1}{m_{n}}\right)\left[K_{A}-K_{B}\right] .
$$

Here, $K_{A}$ and $K_{B}$ refer to the iron force constants in phases A and B, respectively, $m_{d}$ and $m_{n}$ the atomic masses of the denominator $(d)$ and numerator $(n)$ isotopes, respectively and the $3 N$ term (Avogadro's Number) comes from summation over all vibrations in condensed matter (Bigeleisen and Mayer, 1947). 
115 Equation (11) states that the isotopic fractionation at the high temperature limit $(T \rightarrow \infty)$ will approach 116 zero. For a particular element and isotope ratio, most of the equation reduces to a constant term, 117 yielding, for ${ }^{57 / 54} \mathrm{Fe}$ :

$$
\Delta^{\frac{57}{54}} F e_{A-B}=4284 \frac{\left[K_{A}-K_{B}\right]}{T^{2}}
$$

Equally, for ${ }^{56 / 54} \mathrm{Fe}$;

In order to minimise the higher free energy of bonds with higher vibrational frequencies (eq. 9), the heavier isotope is favoured over the lighter one.

In general, higher force constants occur in bonding environments with (see Schauble 2004; Young et al. 2015; Sossi et al. 2016):

ii) lower co-ordination number

iii) covalent bonds

iv) low spin $v s$. high spin (for Fe and other transition metals)

To a first order, the first three controls may be estimated empirically to derive values of $K$ (see Young et al. 2015; Sossi and O'Neill, 2017), considering that the interactions between cations and anions in a lattice site can be described quantitatively with ionic interactions. Variations of $K$ then arise due to a change in the charge and co-ordination of the cation, which are described by the bond valence principle 133 (Pauling 1929):

$$
\bar{s}=\frac{\bar{Z}}{\overline{C_{N}}} .(14)
$$

In this equation, $\bar{s}$ is the bond valence, $\bar{Z}$ is the average charge on the cation, and $\overline{C_{N}}$ the mean coordination number in the mineral. The force constant is then approximated by solving the Born-Landé equation, after Young et al. (2009), which describes the elastic energy of an ionic lattice:

$$
K_{f, F e, O}=-\frac{\bar{s}_{F e} \bar{s}_{0} q^{2}(1-B)}{4 \pi \varepsilon_{0} r^{3}},(15)
$$

where $q$ is the charge on an electron $\left(1.602 \times 10^{-19} \mathrm{C}\right), B$ is the Born exponent, dependent on lattice compressibility (taken to be 12 for minerals), $1 / 4 \pi \varepsilon_{o}$ is Coulomb's constant $\left(9 \times 10^{9} \mathrm{Nm}^{2} / \mathrm{C}^{2}\right)$ and $r$ is the bond length in metres. More quantitative methods for estimating for $K$ are described in section 3.0. 
143 The quantity that drives isotope fractionation, the value of the force constant ( $c f$. eq. 15), may be 144 calibrated via a variety of methods. These include calculating the structure of the phase (theoretical 145 approaches) or by measuring the force constant (spectroscopic methods). Alternatively, methods that 146 involve measurement of the isotopic composition of two or more phases in equilibrium with one another 147 to determine fractionation factors (experimental approaches) are also widely used. All three are 148 described briefly below.

\subsection{Theoretical}

150

Ab-initio simulations are the most common way of determining vibrational frequencies, typically with density functional theory (DFT; e.g., Schauble, 2004), one such class of these computations. DFT models the electronic structure and density of electrons in individual atoms to find the most probable equilibrium ground state electronic configuration. Once this state is defined for a system consisting of $x$ number of atoms, the interatomic distances between them define a molecular structure from which the force constants are calculated. The interested reader is referred to Blanchard and Dauphas (this volume) for a fuller description of the method. A simplified calculation based on the bond valence principle can also yield accurate force constants (eq. 15; Young et al., 2015, 2009; Sossi and O’Neill 2017), though it uses the atomic structure of the phase as an input parameter.

\subsection{Experimental}

Here, the phases of interest are synthesised by subjecting a known composition to a specific pressure and temperature. The isotopic composition of one of the resultant phases is measured with respect to that of a second phase, yielding the fractionation factor, $\alpha^{\frac{n}{\bar{d}}} E_{A-B}$. That the two phases grown experimentally are in equilibrium with one another may be determined by two different means: (i) chemical and isotopic equilibrium is demonstrated to have been obtained between the phases of interest (e.g., by time-series and reversal experiments) and (ii) by the three isotope method (Shahar et al. 2008). Here, a series of experiments that approach equilibrium are performed, and the true equilibrium composition is calculated by extrapolation of the experiments to the known bulk composition. Considerations in designing and interpreting the results of experimentally-determined isotopic fractionation are summarised in Shahar et al. (2017) and in Bourdon et al. (2018).

\subsection{Spectroscopic}

Measurement of force constants relies upon the excitation of the vibrational modes of motion of the mineral lattice by incoming X-rays which collide with a ${ }^{57} \mathrm{Fe}$ nucleus (the only iron isotope sensitive to this effect). Such information can be determined by Mössbauer spectroscopy (Polyakov and Mineev 2000) or by Nuclear-Inelastic Resonant X-Ray Scattering, NRIXS (Polyakov et al. 2007; Dauphas et al. 2012). The latter method is preferred because the characteristics of the impacting photons can be 
tuned and scanned for purpose at a synchrotron. Both of these methods are dealt with in more detail in Blanchard and Dauphas (this volume).

\subsection{Fundamental controls on isotopic fractionation between minerals, melts and fluids}

\subsection{Minerals}

The $\mathrm{Fe}^{3+} / \sum \mathrm{Fe}$ ratio in minerals is controlled by the stoichiometry of the phase. Some series display complete solid solution between compositional end-members, and common igneous examples include:

i) Magnetite-Ulvöspinel: ${ }^{\mathrm{IV}} \mathrm{Fe}^{3+\mathrm{VI}}\left(\mathrm{Fe}^{2+} \mathrm{Fe}^{3+}\right) \mathrm{O}_{4}-{ }^{\mathrm{IV}} \mathrm{Fe}^{2+\mathrm{VI}}\left(\mathrm{Fe}^{2+} \mathrm{Ti}^{4+}\right) \mathrm{O}_{4}$

Magnetite has a complete solid solution with ulvöspinel, an exchange that forms the basis for the Fe-Ti exchange oxybarometer of Buddington and Lindsley (1964) (see also Arató and Audétat, this volume). Both are spinel group minerals sensu lato, with the general formula $\mathrm{AB}_{2} \mathrm{O}_{4}$, where, if the $\mathrm{B}$ cations occupy both the tetrahedral and octahedral sites, the structure is said to be 'inverse'. Magnetite is a 2-3 spinel (one $2+$ cation with two $3+$ ) and has an inverse cation distribution at room temperatures, though it tends to the random distribution at magmatic temperatures around $1000^{\circ} \mathrm{C}(\mathrm{Wu}$ and Mason 1981). Ulvöspinel, a 4-2 spinel, also has an inverse structure with Ti exclusively occupying the octahedral site while ferrous iron is both VI- and IV-fold co-ordinated. Intermediate compositions have site distributions that are temperature-dependent and are controlled by electron exchange between the two valence states of $\mathrm{Fe}$, with the random distribution being favoured at higher temperature (O'Neill and Navrotsky 1984; Wechsler et al. 1984; Bosi et al. 2009).

Shahar et al. (2008) determined the fractionation factor between magnetite and fayalite experimentally in a piston cylinder to be $\Delta^{57} \mathrm{Fe}_{\text {mag-fay }}=+0.30 \times 10^{6} / \mathrm{T}^{2}$, reflecting the preference of heavier iron for the stronger, $\mathrm{Fe}^{3+}$-bearing IV- and VI-fold sites of magnetite relative to the exclusively octahedral ferrous iron in fayalite. Sossi and O'Neill (2017) measured the fractionation factor between magnetite and $\mathrm{FeCl}_{2} \cdot 4 \mathrm{H}_{2} \mathrm{O}$ fluid in piston cylinder experiments in $\mathrm{Ag}$ capsules at $800^{\circ} \mathrm{C}$. They estimated the magnetiteulvöspinel fractionation factor from fits to their experimental data using bond valence theory, giving $\Delta^{57} \mathrm{Fe}_{\text {mag-usp }}=+0.32 \times 10^{6} / \mathrm{T}^{2}$ (Fig. 1), very similar to that measured between magnetite and fayalite. There is considerable disagreement as to the force constant of Fe bonds in magnetite; Polyakov et al. (2007) report a value of $228 \mathrm{~N} / \mathrm{m}$ calculated from NRIXS spectra, similar to that given thereafter by Dauphas et al. (2012), $230 \mathrm{~N} / \mathrm{m}$, using the same technique. Roskosz et al. (2015) report a higher value of $264 \mathrm{~N} / \mathrm{m}$ using NRIXS via extrapolation of trends based on solid solutions of Mg-Fe-Al-Cr spinels, and they note that discrepancies may be due to the quality of the spectra at high energies and the energy range over which spectra are collected. Importantly, though the absolute force constants may vary, the magnitude of mineral-mineral fractionation factors in these studies are in good agreement.

ii) Ilmenite-Hematite: ${ }^{\mathrm{VI}} \mathrm{Fe}^{2+} \mathrm{TiO}_{3}-{ }^{\mathrm{VI}} \mathrm{Fe}^{3+}{ }_{2} \mathrm{O}_{3}$ 
Iron passes from entirely ferrous to entirely ferric along the solid solution series, whilst remaining in octahedral co-ordination (e.g., Wechsler and Prewitt 1984). Ilmenite shows limited solid solution with hematite at the $f \mathrm{O}_{2}$ s typical of igneous systems, where $\mathrm{X}_{\mathrm{Ilm}}$ varies from 0.98 at 2 log units below the Fayalite-Magnetite-Quartz (FMQ) buffer to 0.90 at $\triangle \mathrm{FMQ}+1$ during crystallisation of a dry tholeiitic ferrobasalt (see Toplis and Carroll 1995).

Determinations of force constants in hematite via Mössbauer spectroscopy (Polyakov and Mineev 2000) ab-initio calculations (Blanchard et al. 2009) and NRIXS (Polyakov et al. 2007; Dauphas et al. 2012) are all in good agreement, and yield mean Fe-O force constants of between 235 and $252 \mathrm{~N} / \mathrm{m}$. Note that the spinel trend measured in Roskosz et al. (2015) yields higher values for the purely ferric iron-bearing endmembers, $303 \pm 6 \mathrm{~N} / \mathrm{m}(n=3)$. Polyakov and Mineev (2000) report a force constant for ilmenite of $90 \mathrm{~N} / \mathrm{m}$, and hence a fractionation factor of $\Delta^{57 / 54} \mathrm{Fe}_{\text {hem-ilm }}=4284(235-90) / \mathrm{T}^{2}=0.61 \times 10^{6} / \mathrm{T}^{2}$. Sossi and O'Neill (2017) measured the isotopic fractionation between ilmenite and $\mathrm{FeCl}_{2} \cdot 4 \mathrm{H}_{2} \mathrm{O}$ fluid at 800 ${ }^{\circ} \mathrm{C}$, and estimated the ilmenite-hematite fractionation factor from fits to their experimental data using bond valence theory to give $0.58 \times 10^{6} / \mathrm{T}^{2}$ (Fig. 1). Both fractionation factors are in very good agreement and highlight the importance of mineral composition within a solid solution in determining the isotopic fractionation factor.

iii) Almandine-Pyrope: ${ }^{\mathrm{VIII}} \mathrm{Fe}^{2+}{ }_{3} \mathrm{VI}_{2} \mathrm{Al}_{2}\left[\mathrm{SiO}_{4}\right]_{3}-{ }^{\mathrm{VIII}} \mathrm{Mg}_{3}{ }^{\mathrm{VI}} \mathrm{Al}_{2}\left[\mathrm{SiO}_{4}\right]_{3} ;$ Grossular-Andradite: ${ }^{\mathrm{VIII}} \mathrm{Ca}_{3}{ }^{\mathrm{VI}} \mathrm{Al}^{3+}{ }_{2}\left[\mathrm{SiO}_{4}\right]_{3}-{ }^{\mathrm{VIII}} \mathrm{Ca}_{3}{ }^{\mathrm{VI}} \mathrm{Fe}^{3+}{ }_{2}\left[\mathrm{SiO}_{4}\right]_{3}$

Ferrous iron is dodecahedrally-co-ordinated by oxygen in almandine garnet, a rarity among Fe-bearing minerals, in which it typically occupies VI-fold sites. Ferric iron in andradite garnet is in octahedral coordination.

Sossi and O'Neill (2017) reported fractionation factors between almandine and other Fe-bearing minerals and showed that its iron isotope composition was invariably lighter than all other phases investigated (including $\mathrm{FeCl}_{2}$ fluid) by virtue of its longer $\mathrm{Fe}-\mathrm{O}$ bonds (average of $2.37 \AA$ ). They calculated a force constant of $147 \mathrm{~N} / \mathrm{m}$ for almandine (Fig. 1). No measurements of force constants or fractionation factors involving andradite garnet are presently available. However, natural andraditebearing garnets show heavier iron isotope compositions relative to their ferrous iron-bearing counterparts (Urosevic et al. 2018) while garnet is almost always the isotopically lightest phase in eclogitic rocks (Williams et al. 2009; Huang et al. 2019), reflecting their generally low $\mathrm{Fe}^{3+} / \Sigma \mathrm{Fe}$ in mafic and ultramafic rocks ( $<0.1$; Williams et al. 2009; Berry et al. 2010).

iv) Aegirine-Hedenbergite: $\mathrm{Na}^{\mathrm{VI}} \mathrm{Fe}^{3+} \mathrm{Si}_{2} \mathrm{O}_{6}-\mathrm{Ca}^{\mathrm{VI}} \mathrm{Fe}^{2+} \mathrm{Si}_{2} \mathrm{O}_{6}$

The coupled substitution $\mathrm{NaFe}^{3+}\left(\mathrm{CaFe}^{2+}\right)^{-1}$ across the aegirine (acmite)-hedenbergite series involves a change in ferric to ferrous iron in the same octahedral crystallographic site (the M1 site). This transition 
242 is associated with an increase in mean Fe-O bond length from $2.05 \AA$ in aegirine to $2.15 \AA$ in

243 hedenbergite at igneous temperatures of $\approx 1000^{\circ} \mathrm{C}$ (see Cameron et al. 1973).

244 Both end-members of the series were analysed by Mössbauer spectroscopy and force constants 245 calculated according to the second-order Doppler shift by Polyakov and Mineev (2000), yielding 274

$246 \mathrm{~N} / \mathrm{m}$ for aegirine and $112 \mathrm{~N} / \mathrm{m}$ for hedenbergite, the latter being similar to other ${ }^{\mathrm{VI}} \mathrm{Fe}^{2+}$-bearing silicates

247 determined in the same study (olivine, diopside and enstatite; Polyakov and Mineev 2000). More

248 importantly, the fractionation factor between the two is then $\Delta^{57 / 54} \mathrm{Fe}_{\text {aeg-hed }}=0.68 \times 10^{6} / \mathrm{T}^{2}$, similar in 249 magnitude to that for the exchange of octahedral $\mathrm{Fe}^{2+}$ and $\mathrm{Fe}^{3+}$ in the ilmenite-hematite series (Fig. 1).

$$
\mathrm{Na}_{2}{ }_{2} \mathrm{VI}\left(\mathrm{Mg}, \mathrm{Fe}^{2+}\right)_{3} \mathrm{Al}^{3+}{ }_{2} \mathrm{Si}_{8} \mathrm{O}_{22}(\mathrm{OH})_{2}
$$

Riebeckite-group amphiboles are typically found in alkaline magmatic rocks (cf. Schoenberg et al. 2009). They can contain between $100 \%$ and $40 \%$ of their $\mathrm{Fe}$ as $\mathrm{Fe}^{3+}$, in which ferric iron is ordered on the M2 site and small amounts on the M1 (Hawthorne 1978) whereas glaucophane hosts ferrous iron exclusively, and is distributed across its M1 and M3 sites.

From Mössbauer spectroscopy data, Schoenberg et al. (2009) calculated the beta factors for two riebeckitic amphiboles with $\mathrm{Fe}^{3+} / \sum \mathrm{Fe}$ of 0.46 and 0.44 , and found $10^{3} \ln \beta^{57 / 54} \mathrm{Fe}_{\mathrm{rbk}}=0.90$ and $0.74 \times$ $10^{6} / \mathrm{T}^{2}$ respectively, which correspond to force constants of 214 and $175 \mathrm{~N} / \mathrm{m}$.

vi) Spinel group; hercynite - ferrochromite - magnetite ${ }^{\mathrm{IV}} \mathrm{Fe}^{2+} \mathrm{Al}_{2} \mathrm{O}_{4}-{ }^{\mathrm{IV}} \mathrm{Fe}^{2+} \mathrm{Cr}_{2} \mathrm{O}_{4}-{ }^{\mathrm{IV}} \mathrm{Fe}^{3+}$ ${ }^{\mathrm{VI}}\left[\mathrm{Fe}^{2+} \mathrm{Fe}^{3+}\right] \mathrm{O}_{4}$

Spinel-group minerals are ubiquitous in terrestrial mafic and ultramafic lithologies (e.g., Barnes and Roeder 2001) and show extensive solid solutions with first-row transition metals representing the $A$ and B cations (O’Neill and Navrotsky 1984). Natural spinels tend to exhibit $\mathrm{Cr}-\mathrm{Al}$ or $\mathrm{Fe}^{3+}-\mathrm{Cr}$ exchange, with a paucity of $\mathrm{Fe}^{3+}$-Al spinels caused by positive deviations from ideality and hence a solvus in the binary system (e.g., Petric et al. 1981; Nell et al. 1989). Chromium, owing to its high octahedral site preference energy $\left(6 / 5 \Delta_{\text {oct }}\right)^{1}$, is strongly ordered onto the octahedral site, conferring a normal cation distribution on the spinel structure, meaning $\mathrm{Fe}^{2+}$ is found exclusively on the tetrahedral site. Similarly, $\mathrm{Fe}^{3+}$ is displaced from the octahedral site in magnetite to the tetrahedral site with increasing ferrochromite component (O’Neill and Navrotsky 1984).

Spinels are generally found in association with olivine, for example in mantle peridotites and in komatiitic magmas, and are used together with orthopyroxene to determine oxygen fugacities (e.g., Woodland et al. 1992). In reciprocal solid solution with $\mathrm{Fe}-\mathrm{Mg}$ olivine, $\mathrm{Fe}^{2+}$ substitution is favoured

\footnotetext{
${ }^{1}$ In crystal field theory, $\Delta_{\text {oct }}$ relates to the energy difference between the $d$-shell electrons that are split into the $e_{g}$ and $t_{2 g}$ orbitals. For an octahedral field, $t_{2 g}$ orbitals are stabilised with respect to the barycentre by $2 / 5 \Delta_{\text {oct }}$ and $e_{g}$ by $-3 / 5 \Delta_{\text {oct }}$. Thus, the minimum $\Delta_{\text {oct }}$ is $0\left(e . g\right.$., $\left.\mathrm{Zn}^{2+}, \mathrm{Cu}^{+}\right)$and the maximum is $6 / 5 \Delta_{\text {oct }}\left(e . g\right.$., $\left.\mathrm{V}^{2+}, \mathrm{Cr}^{3+}\right)$.
} 
such that $\mathrm{Cr} /(\mathrm{Cr}+\mathrm{Al})$ increases with increasing $\mathrm{Fe}^{2+} /\left(\mathrm{Fe}^{2+}+\mathrm{Mg}\right)$ (e.g., Poustovetov and Roeder 2000). At high $\mathrm{Fe}^{3+}$ contents, the spinel structure inverts and extensive exchange with Ti occurs as discussed above.

In a comprehensive study of the effect of solid solution on the mean strength of the Fe-O bonds, Roskosz et al. (2015) determined the force constants for eight spinel-group minerals. They focused largely on $\mathrm{Mg}-\mathrm{Al}-\mathrm{Fe}$ spinels with variable $\mathrm{Fe}^{3+} / \sum \mathrm{Fe}$ ratios, from 0 to 1 , and one magnesiochromite composition. Their results show that the $\mathrm{Fe}-\mathrm{O}$ force constant is linearly correlated with $\mathrm{Fe}^{3+} / \sum \mathrm{Fe}$ with only subsidiary influence from other structural parameters, ranging from $207 \pm 14$ in $\mathrm{Fe}^{2+}$-bearing spinels to $303 \pm 6$ $\mathrm{N} / \mathrm{m}(n=3)$ for solely ferric iron-bearing spinels (Fig. 2). These values compare with Fe-O force constants of $197-165 \mathrm{~N} / \mathrm{m}$ for ${ }^{\mathrm{VI}} \mathrm{Fe}^{2+}$-bearing silicates (average $=181 \pm 15 \mathrm{~N} / \mathrm{m}, n=4$ ), namely olivine and orthopyroxene (Roskosz et al. 2015), and hence $\Delta^{57 / 54} \mathrm{Fe}_{\mathrm{sp}(\mathrm{FeII}) \text {-sil(FeII) }}=0.11 \pm 0.08 \times 10^{6} / \mathrm{T}^{2}$. In attempting to characterise the influence of co-ordination environment on iron isotopic fractionation, Sossi and O'Neill (2017) determined the fractionation factor between two spinels; hercynite $\left(\mathrm{FeAl}_{2} \mathrm{O}_{4}\right)$ and chromite $\left(\mathrm{FeCr}_{2} \mathrm{O}_{4}\right)$ and $\mathrm{FeCl}_{2} \cdot 4 \mathrm{H}_{2} \mathrm{O}$ fluid at $800^{\circ} \mathrm{C}$. They calculated force constants of $238 \mathrm{~N} / \mathrm{m}$ and $225 \mathrm{~N} / \mathrm{m}$, respectively, higher than that of fayalite $(178 \mathrm{~N} / \mathrm{m})$, yielding $\Delta^{57 / 54} \mathrm{Fe}_{\mathrm{sp} \text { (FeII)-sil(FeII) }}=0.21 \times$ $10^{6} / \mathrm{T}^{2}$, reflecting the influence of IV-fold $v s$. VI-fold co-ordination of $\mathrm{Fe}$ in spinel and olivine, respectively (Fig. 1). Compilation of spinel-olivine fractionation factors measured in peridotitic rocks show generally positive $\Delta^{57 / 54} \mathrm{Fe}_{\text {sp-ol }}$ at low $\mathrm{Cr} \#\left(\right.$ molar $\left.\mathrm{Cr} /\left(\mathrm{Cr}+\mathrm{Al}+\mathrm{Fe}^{3+}\right)\right)$ compared with negligible or slightly negative $\Delta^{57 / 54} \mathrm{Fe}_{\text {sp-ol }}$ at high $\mathrm{Cr} \#$ (Zhang et al. 2019), in qualitative agreement with lowering of the force constant in chromite with respect to hercynite (Sossi and O’Neill, 2017) though a change in sign is not predicted.

vii) Bridgmanite - Ferropericlase ${ }^{\mathrm{VIII}}\left(\mathrm{Fe}^{2+}, \mathrm{Mg}^{2+}, \mathrm{Fe}^{3+}\right)^{\mathrm{VI}}\left(\mathrm{Fe}^{3+}, \mathrm{Al}^{3+}, \mathrm{Si}^{4+}\right) \mathrm{O}_{3}-{ }^{\mathrm{VI}} \mathrm{Fe}_{\mathrm{x}}\left(\mathrm{Mg}_{1-\mathrm{x}}\right) \mathrm{O}$

Though not a solid solution, it is instructive to assess the body of work for these two minerals given their importance for controlling iron isotopic fractionation in the Earth's lower mantle. Iron is present primarily as ferrous iron in the octahedral site of ferropericlase (cubic) and as $\mathrm{Fe}^{2+}$ and $\mathrm{Fe}^{3+}$ in the dodecahedral A and octahedral B sites of bridgmanite (orthorhombic). The substitution of ferric iron into bridgmanite is strongly facilitated through its coupled substitution with $\mathrm{Al}^{3+}$ (McCammon 1997), which forces $\mathrm{Fe}^{3+}$ onto the dodecahedral site by the mechanism ${ }^{\mathrm{VIII}}\left(\mathrm{Fe}^{2+}, \mathrm{Mg}^{2+}\right)^{\mathrm{VI}} \mathrm{Si}^{4+} \leftrightarrow{ }^{\mathrm{VIII}} \mathrm{Fe}^{3+\mathrm{VI}} \mathrm{Al}^{3+}$ (Vanpeteghem et al. 2006).

Further, the variety of iron spin transitions in lower mantle minerals leads to additional electronic configurations that modify $<\mathrm{Fe}-\mathrm{O}>$ bond lengths and therefore influence isotopic fractionation. At low pressures, the crystal field splitting energy (see footnote 1) is lower than that required to pair electrons, meaning iron exists in its high spin (HS) configuration. However, compression at lower mantle pressures reduces the interatomic distance between $\mathrm{Fe}$ and $\mathrm{O}$, destabilising the $e_{g}$ orbitals and making 
effect is most prevalent in the octahedral sites of ferropericlase and bridgmanite for $\mathrm{Fe}^{2+}$ and $\mathrm{Fe}^{3+}$ respectively (see Lin et al. 2013 for a review). Along a mantle adiabat, ${ }^{\mathrm{VI}} \mathrm{Fe}^{2+}$ in ferropericlase begins the transition from HS to LS near $60 \mathrm{GPa}$ (Badro et al. 2003; Wentzcovitch et al. 2009) and is complete by $120 \mathrm{GPa}$. The transformation is displaced to lower pressures for ${ }^{{ }^{\mathrm{I}}} \mathrm{Fe}^{3+}$ in bridgmanite, occurring over a range from 30 - $70 \mathrm{GPa}$ (Jackson et al. 2005a; Fujino et al. 2012), while ${ }^{\mathrm{VIII}} \mathrm{Fe}^{2+}$ experiences a spin transition only under very high pressures (> 120 GPa; Badro et al. 2004; McCammon et al. 2010).

Rustad and Yin (2009), using DFT simulations, recorded a systematic increase in force constant for ferropericlase $\left(10^{3} \ln \beta^{57 / 54} \mathrm{Fe}_{\mathrm{fp}}=0.145\right.$ at $4000 \mathrm{~K}$ for low spin at $120 \mathrm{GPa}$ and 0.098 for high spin), corresponding to force constants of $\approx 540 \mathrm{~N} / \mathrm{m}$ and $\approx 365 \mathrm{~N} / \mathrm{m}$, respectively. By contrast, no such shift was observed for purely $\mathrm{Fe}^{2+}$-bearing bridgmanite due to the asymmetric distortion of the iron-oxygen bonds, and has $10^{3} \ln \beta^{57 / 54} \mathrm{Fe}_{\mathrm{bg}}$ identical to that of ferropericlase in its LS state. Force constants derived from Polyakov (2009) for $\mathrm{Fe}_{0.25} \mathrm{Mg}_{0.75} \mathrm{O}(P=0-109 \mathrm{GPa})$ and from (Shahar et al. 2016) for $\mathrm{FeO}(P=$ 5 - $39 \mathrm{GPa})$ using NRIXS yield very similar pressure-dependencies; $K_{\mathrm{Fe}-\mathrm{O}}=(2.39 \pm 0.17) P(\mathrm{GPa})+$ $164 \pm 10 \mathrm{~N} / \mathrm{m}$ and $(2.56 \pm 0.16) P(\mathrm{GPa})+169 \pm 4 \mathrm{~N} / \mathrm{m}$, respectively. If extrapolated linearly to $120 \mathrm{GPa}$, these calibrations yield $K_{\mathrm{Fe}-\mathrm{O}}$ between 450 and $475 \mathrm{~N} / \mathrm{m}$, lower than that calculated by Rustad and Yin (2009) for LS ferropericlase. Williams et al. (2012) reported the first direct measurement of the iron isotope composition of experimentally-synthesised Al-bearing $(\approx 0.23$ per formula unit, pfu) bridgmanite, with $\mathrm{Fe}^{3+} / \sum \mathrm{Fe} \sim 0.37$ in equilibrium with iron metal at $24 \mathrm{GPa}$ and $1850{ }^{\circ} \mathrm{C}$. Their preferred $\Delta^{57 / 54} \mathrm{Fe}_{\text {bg-met }}$ is $+1.35 \%$, whose sense is in accord with recent NRIXS determinations of Yang et al. (2019), though the magnitude is much larger ( $\Delta^{57 / 54} \mathrm{Fe}_{\text {bg-met }}$ by NRIXS is $+0.2 \%$ at $2000 \mathrm{~K}$ and $30 \mathrm{GPa}$ ). These authors collected an extensive set of in-situ high-pressure data for ferropericlase $\left(\mathrm{Fe}_{0.25} \mathrm{Mg}_{0.75} \mathrm{O}\right)$ and bridgmanites (both Al-free and Al-bearing at $0.11 \mathrm{pfu}$ ). Bridgmanite reaches a maximum $K_{\mathrm{Fe}-\mathrm{O}}$ of $449 \pm 46 \mathrm{~N} / \mathrm{m}$ (46 GPa), and is isotopically heavier than ferropericlase below $60 \mathrm{GPa}$, after which the latter transitions to its LS state that produces a drastic increase in force constant with a slope of $d K_{F e-O}$ $/ d P$ of $\sim 3 \mathrm{~N} / \mathrm{m} / \mathrm{GPa}$, reaching $626 \pm 31 \mathrm{~N} / \mathrm{m}$ at $94 \mathrm{GPa}$. Above $60 \mathrm{GPa}$, the force constant of bridgmanite is unchanging around $335 \pm 15 \mathrm{~N} / \mathrm{m}$ up to $104 \mathrm{GPa}$, independent of $\mathrm{Fe}^{3+} / \sum \mathrm{Fe}$ and $\mathrm{Al}$ content.

\subsection{Melts}

Because of the lack of long-range order in silicate melts (or fluids), the variation of $\mathrm{Fe}^{3+} / \mathrm{Fe}^{2+}$ is unbound by stoichiometry and can vary freely. The ratio of ferrous to ferric iron in silicate liquids can be understood quantitatively by considering the homogeneous equilibrium:

$$
F e^{3+} O_{1.5}(l)=F e^{2+} O(l)+\frac{1}{4} O_{2} .
$$

The equilibrium constant of this reaction is: 


$$
K^{*}=\frac{a\left(F e^{2+} O\right) f\left(O_{2}\right)^{1 / 4}}{a\left(F e^{3+} O_{1.5}\right)}
$$

Where $a$ refers to the activity of the iron oxide component dissolved in the liquid and $K^{*}$ accounts for their possible deviations from the ideal case $(K)$. Written in terms of $\mathrm{Fe}^{3+} / \sum \mathrm{Fe}$ :

$$
\frac{X F e^{3+} O_{1.5}}{\sum F e}=\frac{1}{1+10^{\left(-\frac{1}{4} \log f\left(O_{2}\right)+\log K-\log \frac{\gamma F e O}{\gamma F e O_{1.5}}\right)}} .
$$

The $\gamma \mathrm{FeO}$ and $\gamma \mathrm{FeO}_{1.5}$ refer to the activity coefficients of these species in the silicate melt referenced to the standard states of the pure liquid oxides at the conditions of interest. Using thermodynamic data for reaction (16), Jayasuriya et al. (2004) calculated values of $\gamma \mathrm{FeO}=1.37$ and $\gamma \mathrm{FeO} \mathrm{O}_{1.5}=1.08 \pm 0.33$ based on $\mathrm{Fe}^{3+} / \mathrm{Fe}^{2+}$ ratios determined by Mössbauer spectroscopy. These determinations are valid at infinite dilution (which they inferred at $1 \mathrm{wt} . \% \mathrm{FeO}^{\mathrm{T}}$ ) in an Anorthite-Diopside eutectic composition at $1400{ }^{\circ} \mathrm{C}$ and 1 bar, meaning that iron dissolution in silicate melts is close to ideal. Furthermore, their data showed that $\log \left(\mathrm{Fe}^{3+} / \mathrm{Fe}^{2+}\right)$ is proportional to $\left(f \mathrm{O}_{2}\right)^{0.245}$, within uncertainty of the theoretical dependence expected from eq. (16), suggestive of no interactions between $\mathrm{Fe}^{2+}-\mathrm{Fe}^{3+}$ in silicate liquids as a function of $f \mathrm{O}_{2}$. This hypothesis, that $\frac{\gamma F e O}{\gamma F e O_{1.5}}$ is independent of $f \mathrm{O}_{2}$ for a fixed composition, was later confirmed by Berry et al. (2018) for a natural MORB composition with higher quantities of iron (10 wt. $\left.\% \mathrm{FeO}^{\mathrm{T}}\right)$.

By contrast, $\frac{\gamma \mathrm{FeO}}{\gamma \mathrm{FeO}_{1.5}}$ is readily affected by silicate composition. Dickenson and Hess (1986) show that potassium stabilises tetrahedrally-co-ordinated ferric iron by charge balance. Recent work by Borisov et al. (2017) illustrates that this stabilisation occurs inversely proportional to their bond valence in silicate melts (e.g. Farges et al. 2004) whereas $\mathrm{Al}$ competes with $\mathrm{Fe}^{3+}$ for tetrahedral sites. This effect is manifest in the higher $\mathrm{Fe}^{3+} / \sum \mathrm{Fe}$ in $(\mathrm{Na}, \mathrm{K})_{2} \mathrm{Si}_{3} \mathrm{O}_{7}$ silicate melts (Knipping et al. 2015) relative to alkalipoor MORB compositions (Berry et al. 2018) at the same $f \mathrm{O}_{2}$.

The effect of composition on $\mathrm{Fe}^{3+} / \sum \mathrm{Fe}$ is evident in the study of Dauphas et al. (2014), the first to combine quantification of X-Ray Absorption Near-Edge Structure (XANES) spectra to determine the redox ratio of glasses with NRIXS spectra to calculate Fe-O force constants. They analysed glass of four different compositions corresponding to basaltic, andesitic, dacitic and rhyolitic liquids melted at $1550^{\circ} \mathrm{C}$ and 1 bar. Notably, the rhyolitic glass has relatively higher $\mathrm{Fe}^{3+} / \sum \mathrm{Fe}$ than the more mafic compositions at the same $f_{2}$. While tempting to correlate this shift with silica content, Borisov and McCammon (2010) show that increasing silica results in decreases in $\mathrm{Fe}^{3+} / \sum \mathrm{Fe}$ up to $60 \% \mathrm{SiO}_{2}$, all else being equal, suggestive instead of the role of alkali metals in stabilising tetrahedrally-co-ordinated $\mathrm{Fe}^{3+}$. Dauphas et al. (2014) report an increase in the Fe-O force constant from $199 \pm 15 \mathrm{~N} / \mathrm{m}$ in $\mathrm{Fe}^{2+}$-bearing mafic-intermediate composition, which they extrapolate to $351 \pm 29 \mathrm{~N} / \mathrm{m}$ for $\mathrm{Fe}^{3+} / \sum \mathrm{Fe}=1$ (Fig. 3). 
Independently of $f \mathrm{O}_{2}$, the rhyolitic composition is displaced to higher Fe-O force constants for a given $\mathrm{Fe}^{3+} / \sum \mathrm{Fe}, 240 \pm 13 \mathrm{~N} / \mathrm{m}\left(\mathrm{Fe}^{3+} / \sum \mathrm{Fe}=0\right)$ and $385 \pm 24\left(\mathrm{Fe}^{3+} / \sum \mathrm{Fe}=1\right)$. This distinction therefore likely reflects the greater proportion of IV-fold co-ordinated $\mathrm{Fe}^{3+}$ in rhyolitic compositions relative to more basic melts. Although ferrous and ferric iron in basaltic glasses have co-ordination numbers close to $\mathrm{V}$ (though this may be through a combination of IV- and VI-fold rather than V-fold itself), ferric iron tends to be in slightly lower co-ordination environments than does ferrous iron (Wilke et al. 2007; Knipping et al. 2015). In both cases, the addition of alkalis stabilises tetrahedrally co-ordinated iron, the effect being more pronounced for $\mathrm{Fe}^{3+}$ (Jackson et al. 2005b; Knipping et al. 2015; Borisov et al. 2017), again inversely proportional to their bond valence $\left(\mathrm{Rb}^{+}>\mathrm{K}^{+}>\mathrm{Na}^{+}>\mathrm{Li}^{+}\right)$.

The relative compressibility of oxide components in silicate melts leads to structural changes as a function of pressure (e.g., Kress and Carmichael 1991) that can affect isotopic fractionation (section 2.0). At equilibrium, differences in molar volumes $(\bar{V})$ of the $\mathrm{FeO}$ and $\mathrm{FeO}_{1.5}$ components with pressure $(P)$ impact upon their stability, with the resultant change in Gibbs Free Energy of formation $\left(\Delta G^{o}\right)$ described by:

$$
\Delta G_{(15), T, P}^{o}=\Delta G_{(15), T, 1 \text { bar }}^{o}+\int_{1 b a r}^{P} \Delta \bar{V}_{T, P} d P,(19)
$$

and, with the relation $\Delta G=-R T \ln K$, the ferric-ferrous ratio is given by:

$$
\ln \left(\frac{X F e O_{1.5}}{X F e O}\right)=-\left(\frac{\Delta G_{(15), T, 1 \mathrm{bar}}^{o}+\int_{1 \mathrm{bar}}^{P} \Delta \bar{\nabla}_{T, P} d P}{R T}\right)-\ln \left(\frac{\gamma F e O_{1.5}}{\gamma F e O}\right)+\frac{1}{4} \ln f O_{2}
$$

The volume change for eq. (16) at 1 bar is negative, such that $\mathrm{FeO}$ would be expected to be stabilised with respect to $\mathrm{FeO}_{1.5}$ with increasing pressure at constant relative $f \mathrm{O}_{2}$, assuming no change in their molar volumes. Calculations of iron redox state by Mössbauer and XANES spectra for iron in andesitic melts at the $\mathrm{Ru}-\mathrm{RuO}_{2}$ oxygen buffer as a function of pressure bear out this prediction, and show increasing $\mathrm{Fe}^{2+} / \mathrm{Fe}^{3+}$ ratios up to $7 \mathrm{GPa}$ (O’Neill et al. 2006; Zhang et al. 2017). This tendency was modelled using a Murnaghan equation of state with molar volumes from Lange and Carmichael (1987) and bulk moduli of $30.3 \mathrm{GPa}$ and $16.6 \mathrm{GPa}$ for $\mathrm{FeO}$ and $\mathrm{FeO}_{1.5}$, respectively (Kress and Carmichael, 1991). Zhang et al. (2017) recognised a densification of the $\mathrm{FeO}$ component by a progressive shift in average iron co-ordination number from 5.5 to 6 over this pressure range, whereas that of $\mathrm{FeO}_{1.5}$ remained constant at $\approx 5.3$. However, higher pressure experiments show that the trend of increasing $\mathrm{Fe}^{2+} / \mathrm{Fe}^{3+}$ is reversed between 7 and $15 \mathrm{GPa}$ (Armstrong et al. 2017) with $\mathrm{Fe}^{2+} / \mathrm{Fe}^{3+}$ decreasing thereafter up to $23 \mathrm{GPa}$, suggesting ferric iron also transitions to higher co-ordination numbers above $15 \mathrm{GPa}$.

Although co-ordination number increases with pressure, the associated bond stiffening (recalling the inverse proportionality of volume and vibrational frequency, eq. (8)) results in considerable increases in $<\mathrm{Fe}-\mathrm{O}>$ force constants in silicate glasses (Liu et al. 2017). At ambient pressure, $K_{\mathrm{Fe}-\mathrm{O}}$ in $\mathrm{Fe}^{3+}$-free basaltic glass is $\approx 190 \mathrm{~N} / \mathrm{m}$ (Fig. 3; Dauphas et al. 2014) whereas it reaches $355 \mathrm{~N} / \mathrm{m}$ at $65.4 \mathrm{GPa}$ (Fig. 
4; Liu et al. 2017); equivalent to the effect of quantitative substitution of ferrous for ferric iron at 1 bar.

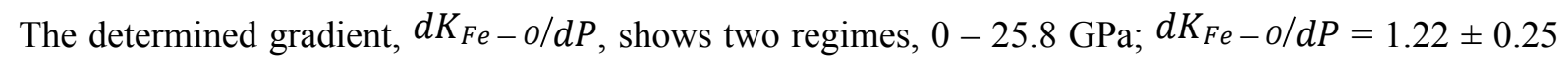
$\mathrm{N} / \mathrm{m} / \mathrm{GPa}$ and $35.1-65.4 \mathrm{GPa} ; d K_{F e}-o / d P=1.81 \pm 0.10 \mathrm{~N} / \mathrm{m} / \mathrm{GPa}$, with a discontinuous jump between them (Fig. 4). Therefore, despite evidence for a gradual increase in $\mathrm{FeO}$ co-ordination number in silicate glasses under conditions that are relevant to partial melting in the upper mantle $(<7 \mathrm{GPa}$, Zhang et al. 2017), this structural change induces little- or no increase in $K_{\mathrm{Fe}-\mathrm{O}}$. By contrast, the step-wise increase in $K_{\mathrm{Fe}-\mathrm{O}}$ from $\approx 220 \mathrm{~N} / \mathrm{m}$ to $\approx 300 \mathrm{~N} / \mathrm{m}$ between $25-35 \mathrm{GPa}$ coincides with pronounced densification in basaltic melts, inferred to be caused by the passage of Si from tetrahedral to octahedral co-ordination (Sanloup et al. 2013). Therefore, bulk structural changes in the melt may be more effective in modifying $\mathrm{Fe}-\mathrm{O}$ force constants than are changes in local bonding environment.

\subsection{Fluids}

The compositional parameter space for fluids is larger than that for silicate melts, in which most components are dissolved as oxide species. By contrast, metals can be complexed by Cl-, C-, S- and OH ligands in geologically-relevant fluids (see Burnham 1979; Candela 1989; Manning 2004; Richards 2011 for summaries of fluid compositions in arc magmatic and hydrothermal systems). Magmatic fluids are predominantly aqueous, with dissolved components ranging from 17 - 83\% (Manning 2004), which are broadly correlative with the $P-T$ conditions at which the fluid equilibrated. Low temperature fluids have metal-bearing species dominated by alkali-chloride complexes $(\mathrm{NaCl}, \mathrm{KCl})$, in addition to $\mathrm{HCl}$ and $\mathrm{SO}_{2}$ as other major volatiles (e.g., Richards 2011). The dissolution of Si becomes important at higher temperatures as the composition of the fluid-rock system approaches supercritical behaviour, which occurs at $1.5 \mathrm{GPa}$ and $700^{\circ} \mathrm{C}$ in the system albite- $\mathrm{H}_{2} \mathrm{O}$ (Manning, 2004).

Iron, like the alkali metals, likely dissolves as Cl-bearing species in hydrothermal fluids, as evidenced by its strong solubility in Cl-rich fluids (e.g., Kwak et al. 1986). It is expected to be predominantly ferrous; the stability of ferric chloride species are much lower (Testemale et al. 2009; Saunier et al. 2011) except during dissolution under very oxidising conditions (e.g., with hematite; Brugger et al. 2016). Spectroscopic techniques that have been employed to probe speciation in acidic chloride solutions for a range of $\mathrm{Cl}$ molalities from 0.5 to 12 up to $450{ }^{\circ} \mathrm{C}$ suggest the presence of higher-order complexes, with the predominance of $\mathrm{FeCl}_{4}{ }^{2-}$ as the dominant Fe-bearing species (Testemale et al. 2009). By contrast, speciation of Fe in fluids at relevant $P$ - $T$ conditions (up to $650^{\circ} \mathrm{C}, 2 \mathrm{kbar}$; Chou and Eugster 1977; Boctor et al. 1980; Fein et al. 1992) is largely informed by the stoichiometry of mineral dissolution reactions. Iron solubility in fluids is expected to be influenced by temperature, pressure, $\mathrm{pH}$ and by the presence of chlorine. The data of Chou and Eugster (1977) on magnetite solubility in $\mathrm{HCl}$ solutions conform to a stoichiometry with $\mathrm{FeCl}_{2}$ as the stable fluid species, whose solubility is given as $\operatorname{logm}\left(\mathrm{FeCl}_{2}\right)=6887 / \mathrm{T}(\mathrm{K})-8.44^{2}$. Ding \& Seyfried (1992) experiments showed that $(\mathrm{FeCl})^{+}$and

\footnotetext{
${ }^{2} \mathrm{~m}$ refers to the molality, in $\mathrm{mol} / \mathrm{kg}$; whereas mmolal refers to $\mathrm{mmol} / \mathrm{kg}$
} 
particularly $\mathrm{FeCl}_{2}$ are the dominant $\mathrm{Fe}$ species in aqueous fluids at the hematite-magnetite buffer and up to $450{ }^{\circ} \mathrm{C}$ and 0.3 to $0.5 \mathrm{kbar}$. The solubility of Fe increases drastically with increasing $\mathrm{NaCl}$ concentrations, passing from $0.369 \mathrm{mmolal}$ of $\mathrm{Fe}$ at $350^{\circ} \mathrm{C}$ and $29.1 \mathrm{mmolal}$ of $\mathrm{Na}$ to $1.285 \mathrm{mmolal}$ of $\mathrm{Fe}$ at $500^{\circ} \mathrm{C}$ and $1233 \mathrm{mmolal}$ of $\mathrm{Na}$ (see also Fig. 12 in Testemale et al., 2009). These authors also observed $\mathrm{FeCl}_{2}$ as the dominant species with increasing temperatures. Indeed, thermodynamic calculations at high pressure and temperature $\left(630-660^{\circ} \mathrm{C}\right.$ and $\left.2 \mathrm{GPa}\right)$ show that $\mathrm{Fe}$ is mobile in slabderived fluids as $\mathrm{FeCl}_{2}$ during antigorite breakdown (Debret \& Sverjensky, 2017). It should be noted that the complexation of $\mathrm{Fe}^{2+}$ with sulfate, carbonate or silica was not considered in these thermodynamic models due to the absence of thermodynamic data; although this is not proof that these species do not exist. Furthermore, even though $\mathrm{Fe}^{3+}$-complexes were included, they were found to be unimportant at the investigated conditions.

These studies all point to the predominance of $\mathrm{FeCl}_{2}$, particularly at high temperatures. Nevertheless, there is a dearth of experimental studies at conditions relevant to that of subduction zone magmatism or high-temperature ore-forming hydrothermal fluids $\left(>800{ }^{\circ} \mathrm{C}\right)$. One of the few are the magnetite solubility experiments of Simon et al. (2004) who also presumed $\mathrm{FeCl}_{2}$ as the stable species and measured up to 7.3 wt. \% iron in the fluid phase at high $\mathrm{NaCl}$ molalities. Sanchez-Valle et al. (2017) recorded XANES spectra of chlorinated-aqueous fluids equilibrated with Fe-bearing minerals in a diamond anvil cell at $2.5 \mathrm{GPa}$ and $800^{\circ} \mathrm{C}$. Their results imply the transport of $\mathrm{Fe}$ with $\left(\mathrm{Fe}^{2+} \mathrm{Cl}_{\mathrm{x}}\right)^{2-\mathrm{x}}$ stoichiometries, with the stability of $\mathrm{Fe}^{3+}$-bearing chloride species decreasing with increasing temperature.

In a series of studies, Hill and co-workers calculated and measured experimentally the isotopic fractionation between a variety of iron chlor-aquo species at ambient temperatures (Hill and Schauble 2008; Hill et al. 2009, 2010). These studies show several trends at $298 \mathrm{~K}$ :

1) The iron isotope fractionation factor and calculated force constants decrease with increasing chlorinity. Specifically, $10^{3} \ln \beta^{56 / 54} \mathrm{Fe}\left(\mathrm{FeCl}_{\mathrm{x}}\left(\mathrm{H}_{2} \mathrm{O}\right)_{6-\mathrm{x}}\right)^{3-\mathrm{x}}$ is $9.41,8.54,8.10,7.13$ and 7.14 for $\mathrm{x}$ $=0,1,2,3$ and 4 , respectively.

2) In the equivalent ferrous-iron bearing system, the species have $10^{3} \ln \beta^{56 / 54} \mathrm{Fe}\left(\mathrm{FeCl}_{\mathrm{x}}\left(\mathrm{H}_{2} \mathrm{O}\right)_{6-\mathrm{x}}\right)^{2-\mathrm{x}}$ of $6.39,5.98$, and 5.91 for $\mathrm{x}=0,1$, and 2 , respectively.

3) Regardless of the basis set used for the ab-initio calculations, the fractionation factor $10^{3} \ln \alpha_{3+-}$ ${ }_{2+} \approx 3 \%$.

Fujii et al. (2014) calculated $\beta$ factors for a host of aqueous, ferric- and ferrous iron-bearing species (Fig. 5). Though there are minor differences in $10^{3} \ln \beta^{56 / 54} \mathrm{Fe}$ among species of a given Fe oxidation state, these differences become small $(<0.3 \%)$ by $573 \mathrm{~K}$. Invariably, species with chloride ligands are the lightest among other species studied, particularly compared to $\mathrm{PO}_{4}^{3-}, \mathrm{OH}^{-}$and $\mathrm{SO}_{4}{ }^{2-}$ which are stronger-field ligands and therefore concentrate the heavier isotopes (Fig. 5). A similar order can be 
474 observed among $\mathrm{Fe}^{3+}$-bearing compounds (Fig. 5). As per the study of Hill et al. (2010), the isotopic 475 fractionation between $\mathrm{Fe}^{2+}$ and $\mathrm{Fe}^{3+}$-bearing species is most marked. At $573 \mathrm{~K}$, the value of $10^{3} \ln \beta^{56 / 54} \mathrm{Fe}_{3+-2+} \approx 0.90 \%$, suggesting iron isotopes should be a powerful discriminant of the oxidation state of iron in fluids, even at high temperatures, but not between different ligands for the same oxidation state of iron.

Iron isotope compositions of chlorine-bearing fluids relevant to hydrothermal systems $\left(300-350{ }^{\circ} \mathrm{C}\right)$ were explored for the systems fluid-pyrite (Syverson et al. 2013) and fluid-chalcopyrite (Syverson et al. 2017). Solutions equilibrated with pyrite contained $\approx 10 \mathrm{mmol} / \mathrm{kg} \mathrm{Fe}^{2+}$ and $\approx 1000 \mathrm{mmol} / \mathrm{kg} \mathrm{Na}$, and, at low $\mathrm{pH}\left(\approx 3\right.$ at $\left.350^{\circ} \mathrm{C}\right)$ and 500 bar, $\mathrm{Fe}\left(\mathrm{H}_{2} \mathrm{O}\right)^{2+}$ was calculated to have been stable, and defined a fractionation factor $10^{3} \ln \alpha\left({ }^{57 / 54} \mathrm{Fe}_{\text {pyr-fluid }}\right)=+1.49 \pm 0.44 \%$. This gives a force constant for $\mathrm{Fe}\left(\mathrm{H}_{2} \mathrm{O}\right)^{2+}$ of $\approx 150 \mathrm{~N} / \mathrm{m}$ (given that of pyrite is $\approx 280 \mathrm{~N} / \mathrm{m}$; Blanchard et al. 2009). Under the same conditions, the fractionation between chalcopyrite and fluid, $10^{3} \ln \alpha\left({ }^{57 / 54} \mathrm{Fe}_{\text {ccp-fluid }}\right)=+0.09 \pm 0.17 \%$ is negligible within uncertainty (Syverson et al. 2017). At $300{ }^{\circ} \mathrm{C}$ and $\mathrm{NaCl}-\mathrm{HCl} \pm \mathrm{FeCl}_{2}$ fluids, dissolution/precipitation of hematite yielded $10^{3} \ln \alpha\left({ }^{57 / 54} \mathrm{Fe}_{\text {hem-fluid }}\right)=+0.54 \pm 0.15 \%$ in which the fluid species was likely $\mathrm{FeCl}_{2}{ }^{0}(\mathrm{aq})$ or $\mathrm{FeCl}^{+}$, however no fractionation was observed at $450{ }^{\circ} \mathrm{C}$ and 600 bar, nor at $200{ }^{\circ} \mathrm{C}$, where the fluid phase was inferred to be dominated by $\mathrm{Fe}^{3+}$-bearing aqueous species (Saunier et al. 2011). Nevertheless, this sequence of isotopic fractionation $\left(\delta^{57} \mathrm{Fe}_{\mathrm{pyr}}>\delta^{57} \mathrm{Fe}_{\text {hem }}>\delta^{57} \mathrm{Fe}_{\text {mag }}>\delta^{57} \mathrm{Fe}_{\text {ccp }} \geq \delta^{57} \mathrm{Fe}_{\text {fluid }}\right)$ is borne out in measurements of hydrothermally-precipitated ore phases (Wawryk and Foden 2015, 2017; Li et al. 2018). Higher temperature experiments carried out at $800^{\circ} \mathrm{C}$ and $10 \mathrm{kbar}$ by Sossi and O'Neill (2017) found strong isotopic fractionation between $\mathrm{FeCl}_{2} \cdot 4 \mathrm{H}_{2} \mathrm{O}$ fluid and $\mathrm{Fe}^{3+}$-rich minerals (namely magnetite $)$, where $10^{3} \ln \alpha\left({ }^{57 / 54} \mathrm{Fe}_{\text {mag-fluid }}\right)=+0.44 \pm 0.01 \%$. By contrast, ${ }^{\mathrm{VI}} \mathrm{Fe}^{2+}$-bearing minerals (fayalite, ilmenite) had similar iron isotope compositions to the fluid, and almandine garnet was lighter still, at $10^{3} \ln \alpha\left({ }^{57 / 54} \mathrm{Fe}_{\text {alm-fluid }}\right)=-0.14 \pm 0.03 \%$, which gives the iron force constant for $\mathrm{FeCl}_{2}{ }^{0}$ in the fluid of $175 \mathrm{~N} / \mathrm{m}$. This compares well with force constants of $153-186 \mathrm{~N} / \mathrm{m}$ for $\mathrm{FeCl}_{2}\left(\mathrm{H}_{2} \mathrm{O}\right)_{4}$ calculated in Hill et al. (2010) depending on the DFT basis set used, their Table A1.

\subsection{Effect of redox processes in influencing iron isotope fractionation in natural systems}

\subsection{Magmatic processes}

\subsubsection{Partial Melting}

502 Partial melting is the process that describes the incomplete transformation of a solid(s) to a liquid phase. 503 In terrestrial magmatic settings, this process can occur in both the crust and mantle. Should liquid-solid segregation occur, this process has the capacity to impart isotopic fractionation on its constituent phases. Though early studies considered that the compositions of mantle peridotites and basaltic rocks were indistinguishable (e.g. Zhu et al. 2001; Beard et al. 2003a) leading to the development of the concept 
perception. In particular, two studies, Williams et al. (2005) and Weyer and Ionov (2007) presented an extensive number of analyses of whole rock peridotites and, in the case of the former, their constituent minerals. The conclusion from both of these works was that peridotitic rocks were isotopically lighter $\left(\delta^{57} \mathrm{Fe}=+0.03 \pm 0.05 \%\right.$ at $\mathrm{Mg} \#=0.894$, that of fertile mantle $)$ than their basaltic counterparts and secondly, that partial melting of the mantle could induce resolvable isotopic fractionation in which the residual peridotite composition would tend to lighter isotopic values with progressive extraction of heavier basaltic melt. Weyer and Ionov (2007) assigned bulk peridotite-liquid fractionation factors that fit arrays of $\delta^{57} \mathrm{Fe} v s$. $\mathrm{Mg} \#\left(\right.$ molar $\left.\mathrm{Mg} /\left(\mathrm{Mg}+\mathrm{Fe}^{2+}\right)\right)$ to quantify this effect, finding $10^{3} \ln \alpha\left({ }^{57 / 54} \mathrm{Fe}_{\text {mantle-melt }}\right)$ $=-0.1$ to $-0.3 \%$. These fractionation factors were also used to fit the observation of the isotopically heavy $\left(\delta^{57} \mathrm{Fe}=+0.15 \%\right.$ ) compositions of basaltic rocks measured to that stage.

518 As recognised by Williams et al. (2005) and Weyer and Ionov (2007), iron isotope fractionation arises 519 mechanistically from the incompatibility of $\mathrm{Fe}^{3+}$ relative to $\mathrm{Fe}^{2+}$, reflected in the higher $\mathrm{Fe}^{3+} / \sum \mathrm{Fe}$ of 520 MORB glasses (0.10 \pm 0.02 ; Berry et al. 2018) relative to peridotites (0.037, Canil et al. 1994). 521 Clinopyroxene is the major contributor to partial melting at low pressures ( $<3 \mathrm{GPa}$ ) (e.g., Hirschmann et al. 1999), and $\mathrm{D}\left(\mathrm{Fe}^{2+}\right) / \mathrm{D}\left(\mathrm{Fe}^{3+}\right)^{3} \approx 10$, where $\mathrm{D}\left(\mathrm{Fe}^{2+}\right) \approx 1$ (e.g., Mallmann and O'Neill 2009; Davis et al. 2013). Therefore, during melt extraction, the modal olivine content increases and, as it contains less ferric iron than ortho- and particularly clinopyroxene or spinel (Canil and O'Neill 1996), tends to concentrate the lighter isotopes. Dauphas et al. (2009) developed a melting model predicated on the difference of $\mathrm{Fe}^{3+} / \mathrm{Fe}^{2+}$ ratios of the mantle source and the partial melt. As ferric iron behaves as an incompatible element, the extent of isotopic fractionation is highest in the melt at low degrees of melting, a feature also attributable to the mass balance considerations (i.e., the 'lever rule'). However, this treatment implicitly neglected the effect of co-ordination environment, whose isotopic effect was unconstrained until the study of Dauphas et al. (2014), whose measurement of Fe-O force constants in magmatic glasses revealed a preference for the heavier isotopes in lower co-ordination environments (section 4.2.). With this knowledge, combined with $K_{F e-O}$ of mantle minerals, Sossi and O'Neill (2017) were able to build self-consistent modal and non-modal melting equations based on the mass balance equations of Shaw (1970), re-cast in terms of isotopic fractionation between phases 1 and 2:

$$
\frac{C_{l}^{i}}{C_{o}^{i}}=\frac{1}{\left(\left(D_{1-2}^{i} \alpha^{j} E_{1-2}\right)+F\left(1-P\left(D_{1-2}^{i} \alpha^{j} E_{1-2}\right)\right)\right)^{\prime}}
$$

where $C_{l}^{i}$ and $C_{o}^{i}$ denote the concentration of isotope $i$ of element $E$ in the liquid and bulk, respectively, $F$ is the melt fraction and $P$ the product of a phase's melting reaction coefficient and elemental $D$

\footnotetext{
${ }^{3}$ The elemental partition coefficient, denoted ' $D$ ', is given by the ratio of the concentration of the element in a solid phase with respect to that in the liquid phase.
} 
summed over each phase. Solutions are found for the concentration of each isotope, and hence the resulting isotopic composition of the liquid is:

$$
10^{3} \ln \left(\frac{C_{l}^{i}}{C_{l}^{j}}\right)=\delta^{i} E .
$$

The above equations can be applied to any isotope system. For iron, the crucial free variable, $D_{1-2}^{i}$, is controlled by the temperature and difference in iron force constants between phases 1 and 2 (mineral and melt):

Here, $n=2\left({ }^{56 / 54} \mathrm{Fe}\right)$ or $3\left({ }^{57 / 54} \mathrm{Fe}\right)$. The force constant for each phase is given in the form:

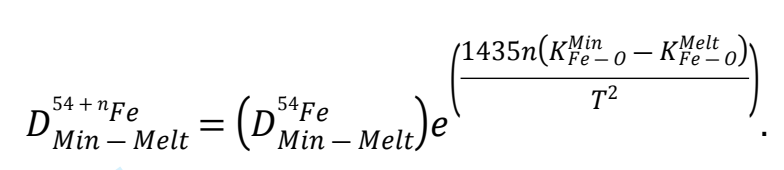

$$
K_{F e-O}=a \times \frac{F e^{3+}}{\Sigma F e}+b
$$

where $a$ describes the slope of the dependence of the force constant with the $\mathrm{Fe}^{3+} / \sum \mathrm{Fe}$, and $b$ the $\mathrm{y}$ intercept, which depends on co-ordination (VIII $<\mathrm{VI}<\mathrm{IV}$ ). Values of constant $a$ and $b$ can be calculated from Figs. ( 1 - 3), and yield $a=125$ and $b_{\mathrm{VIII}}=145 \mathrm{~N} / \mathrm{m}, b_{V I}=185 \mathrm{~N} / \mathrm{m}$ and $b_{I V}=225 \mathrm{~N} / \mathrm{m}$.

Systematics of iron isotope fractionation applying this partial melting model are summarised in Figs. $6 \mathrm{a}$ and $\mathrm{b}$. As in the models presented in Dauphas et al. (2009), iron isotope fractionation between the melt and its source is inversely proportion to the melt fraction (Fig. 6a), as the $\mathrm{Fe}^{3+} / \sum \mathrm{Fe}$ of the melt is maximised at low $F$ due to the relative incompatibility of ferric iron. Independent of this effect is the modal mineralogy of the source; as the modal abundance of garnet increases at the expense of olivine (e.g., via increasing pressure or in a bimineralic eclogite), the fractionation factor increases due to the retention of the light isotopes in its VIII-fold sites.

This mineralogical control on the extent of iron isotope fractionation can account for the isotopic differences between mantle peridotites, MORBs and OIBs. The iron isotope variations observed in mantle peridotites are more scattered than those in basaltic rocks. Studies reporting analyses of peridotitic or ultramafic lithologies include (Poitrasson et al. 2004, 2013; Williams et al. 2004, 2005, 2009; Weyer et al. 2005; Weyer and Ionov 2007; Zhao et al. 2010, 2012, 2017; Huang et al. 2011; Craddock et al. 2013; Sossi et al. 2016) and were summarised by Sossi et al. (2016), who filtered the data for unmetasomatised, unaltered, and fertile peridotites. This procedure greatly reduced data variability enabling a $2 \mathrm{SE}$ uncertainty to be taken of 60 peridotite analyses that yielded $\delta^{57} \mathrm{Fe}=+0.05$ $\pm 0.01 \%$ for the value of fertile mantle. These authors noted that significant iron isotope fractionation in fresh, unmetasomatised peridotites was not evident until reaching Mg\#s $>0.91$, reflecting the retention of the bulk of the iron budget in the peridotite. 
Relative to ultramafic rocks, oceanic basalts almost exclusively preserve heavier iron isotope compositions (Weyer and Ionov 2007). Nevertheless, data for oceanic basalts remained sporadic until the study of Teng et al. (2013), in which 93 iron isotope analyses of basaltic rocks were presented, comprising 43 MORBs, whereas the remainder were OIBs from the Society Islands, the Cook-Austral chain and Hawai'i. The isotopic composition of MORB gave a mean value of $\delta^{57} \mathrm{Fe}=0.15 \pm 0.01 \%$ o (2SE, $n=43$ ), some $0.1 \%$ heavier than fertile mantle. Considering that the maximum iron isotope fractionation permitted during melting of peridotite in the spinel facies is $0.05 \%$ at FMQ (Fig. 6a), this poses a conundrum for the derivation of MORB from peridotitic upper mantle (see discussion in Dauphas et al. 2014). However, as noted by Sossi et al. (2016), MORBs have Mg\#s that are too low $(0.54<\mathrm{Mg} \#<0.68)$ to have been in equilibrium with $\mathrm{Fo}_{90}$ mantle olivine, which, since $\mathrm{K}_{\mathrm{D}}{ }^{\mathrm{Fe}-\mathrm{Mg}}$ $\left(\left[\mathrm{Fe}^{2+} / \mathrm{Mg}\right]_{\mathrm{Ol}} /\left[\mathrm{Fe}^{2+} / \mathrm{Mg}\right]_{\text {Melt }}\right.$ ) is equal to $\approx 0.3$ (Toplis 2005 ), should produce melts with $\mathrm{Mg} \# \approx 0.74$ (compositional effects on $\mathrm{K}_{\mathrm{D}}{ }^{\mathrm{Fe}-\mathrm{Mg}}$ broadly cancel such that the use of a single value introduces minimal uncertainty). In this scenario, the low-pressure evolution of MORB magmas during decompression expands the olivine phase volume (Kinzler and Grove 1992) and light iron isotopes preferentially sequestered into olivine, resulting in heavier values than could be accounted for by single-stage melt extraction. Correction of the iron isotope composition of MORB to a fictive primary melt composition with $\mathrm{Mg} \# \approx 0.74$ yields $\delta^{57} \mathrm{Fe}=0.10 \%$ (Sossi et al. 2016) that can be reconciled with partial melting. Additional possibilities, including diffusive effects during partial melting (e.g., Weyer and Ionov 2007; Poitrasson et al. 2013; Su et al. 2015), may also become important in fractional melting regimes where melt parcels and residual mantle equilibrate only at infinitesimally small increments (see Asimow et al. 1997). Here, preferential transport of the lighter iron isotopes into peridotite minerals during ascent, due to its faster diffusivity, would lead to heavier isotopic compositions than predicted by equilibrium fractionation factors.

With respect to MORBs, OIBs are frequently (though not always; Peters et al. 2019) higher in $\delta^{57} \mathrm{Fe}$ (Teng et al. 2013), a tendency that was highlighted in the data of Williams and Bizimis (2014) and Konter et al. (2016) on MgO-rich pyroxenites and OIBs from Hawai'i and Samoa, respectively. In these samples, whose $\mathrm{Mg} \#$ reaches $0.69, \delta^{57} \mathrm{Fe}$ can extend to $+0.45 \%$, up to $0.4 \%$ o heavier than recent estimates for fertile mantle peridotite. All things being equal, OIBs should be heavier than MORBs by virtue of the lower degrees of partial melting involved in their genesis (section 5.1.1., Fig. 6). Nevertheless, this offset is greater than can be produced by degree of melting alone, and the combination of isotopically heavy iron and high $\mathrm{Mg} \#$ requires additional source-related melting controls. Both studies argue for the presence of pyroxenite in the source, which has the dual effect of i) increasing the $\delta^{57} \mathrm{Fe}$ of the source (pyroxenites from Oahu, Hawai'i have $\delta^{57} \mathrm{Fe}$ between +0.10 and $+0.27 \%$, Williams and Bizimis, 2014) and ii) enhancing iron isotope fractionation during partial melting. This second point was quantified in Sossi and O'Neill (2017) who demonstrated that such heavy values were difficult to 
604 that simultaneously acted as a sink for light iron isotopes (see Fig. 6a) and increased the $\mathrm{Gd} / \mathrm{Yb}$ ratio of 605 the basalts (Fig. 7).

606 The expected effect of source oxidation is to increase the iron isotope fractionation observed in products 607 of partial melting (Dauphas et al. 2009; Fig. 6b). Although the consensus is that arc magmas are more 608 oxidised than those from oceanic settings (MORBs and OIBs; see Carmichael 1991; Kelley and Cottrell 609 2009), conjecture still abounds as to whether the sources of arc magmas are more oxidised than their 610 equivalents under mid-ocean ridges or ocean islands (Lee et al. 2005; Mallmann and O'Neill 2009). In 611 this scenario, the higher oxygen fugacity of arc magmas could be acquired after segregation from their 612 mantle sources, by fractional crystallisation or degassing of reduced species, such as $\mathrm{H}_{2}$ or $\mathrm{CH}_{4}(\mathrm{Mathez}$ 613 1984). The sensitivity of iron isotopes to the redox state of iron may in turn be able to distinguish 614 between these two hypotheses.

615 Should the sources of arc magmas be more oxidised, then the mechanics of iron isotope fractionation 616 would predict an iron isotope composition heavier than oceanic basalts. Analyses of arc magmas were, 617 until recently, surprisingly sparse, restricted to studies of back-arc basalts (Nebel et al. 2013;2018) and 618 two arcs; New Britain (Dauphas et al. 2009) and the sediment-rich Banda (Nebel et al. 2015) prior to 619 the extensive dataset comprising 130 arc magmas of Foden et al. (2018). These authors discovered, 620 contrary to expectations, that arc magmas have systematically lighter iron isotope composition relative 621 to MORBs, extending to values even lighter than fertile mantle peridotites, around $-0.15 \%$ in 622 Avachinsky, Klyuchevskoy and Ploskiy volcanoes of the Kamchatka arc (Foden et al. 2018). This result 623 has two important implications. Firstly, if the sources of arc magmas are indeed more oxidised than 624 ambient mantle, then iron itself cannot be the cause of this oxidation. Rather, the role of $\mathrm{S}^{6+}$ as the 625 oxidising agent for arc magmas is supported by quantitative calculations of the redox budget of 626 subduction zones (Evans and Tomkins 2011), largely due to its efficiency in oxidising iron via an 8627 electron transition from sulfate to sulfide:

$$
S^{6+}+8 F e^{2+}=S^{2-}+8 F e^{3+} .
$$

629 This means 8 moles of Fe are oxidised for every mole of S, which equates to 1.8 wt. \% FeO per 1000 $630 \mathrm{ppm}$ S; the S content of MORB, though those of arc magmas are even higher (Wallace and Edmonds 631 2011). This comes about due to the higher solubility of sulfur in silicate melts at anhydrite saturation 632 with respect to sulfide saturation (O’Neill and Mavrogenes 2002; Li and Ripley 2009; Smythe et al. 633 2017). Alternatively, the idea that the oxygen fugacities of arc magma sources are similar to ambient 634 mantle stands. In either case, iron isotopes show no evidence for the oxidation of arc magmas sources.

635 Secondly, the observation that arc magmas are lighter than oceanic basalts begs explanation. Nebel et 636 al. (2015) argued that the isotopically light sources could be generated by the prior extraction of melt 637 from peridotite sources, which are known to be more refractory than ambient mantle on the basis of 
638 lower abundances of incompatible high field strength elements ( $\mathrm{Nb}, \mathrm{Ti})$ in arc magmas. These elements 639 behave conservatively during slab fluid transfer to the mantle wedge and represent the composition of 640 mantle wedge peridotite (Woodhead et al. 1993). Degrees of partial melting needed to explain the degree of isotopic fractionation is close to $30 \%$, which are observed in xenoliths from the Bismarck arc 642 (Bénard et al. 2018). However, Foden et al. (2018) asserted that values as low as $-0.15 \%$ cannot be 643 produced by melt depletion alone, and considered additional scenarios. In particular, diffusive stripping 644 of lighter isotopes in preference to their heavier counterparts was cited as a mechanism to promote light isotope compositions in partial melts. As discussed in section 4.3., the iron isotope composition of aqueous fluids are light provided the speciation of iron is dominated by $\mathrm{Fe}^{2+}$-bearing species, particularly $\mathrm{FeCl}_{2}$, as inferred from the measurements of Sanchez-Valle et al. (2017). However, it remains uncertain as to whether the Fe content of these fluids is high enough to shift the iron isotope composition of the mantle wedge (Ayers et al. 1997; see also section 5.2.3). Indeed, supra-subduction zone ophiolitic peridotites, despite their high degree of depletion $(\approx 25-35 \%)$ and re-enrichment with subduction zone fluids, resulting in a distinctive 'U-shape' REE pattern, are not systematically lighter than abyssal peridotites ( $\mathrm{Su}$ et al. 2015; Zhang et al. 2019). Although certain samples extend to the requisite light values $\left(\delta^{57} \mathrm{Fe} \approx-0.15 \%\right.$ ), this variation is, at best, weakly-dependent on proxies for degree of melt extraction ( $\mathrm{Mg} \#, \mathrm{Cr} \#$ in spinel or clinopyroxene) or fluid addition $(\mathrm{Ba} / \mathrm{Th}, \mathrm{Ba} / \mathrm{La})$. By contrast, Turner et al. (2018) observe a positive correlation between $\delta^{57} \mathrm{Fe}$ and $\delta^{7} \mathrm{Li}$ to very low values (-0.46\%o and $-1.78 \%$, respectively), pointing to fluid addition and/or diffusive processes, though the primary mechanism for inducing these variations remains uncertain. Further studies of sub-arc mantle peridotites are required to evaluate the degree to which these process are liable to affect their iron isotopes compositions locally.

On a global scale, Foden et al. (2018) recognised a negative correlation between the iron isotope composition of global arc magmas and the thermal parameter $(\phi)$ :

$$
\phi=a g e \times \sin \theta u,(26)
$$

the product of slab age and vertical descent velocity, $u$, where $\theta$ is the dip angle (Kirby et al. 1996) 664 (Fig. 8). Subducting slabs that are old and cold tend to descend at faster rates, such that they do not thermally equilibrate as much with surrounding mantle, and slab geotherms are too cold to permit slab melting. By contrast, hotter slabs descend more slowly due to their thermal buoyancy, and hence heat up to greater extents during their protracted residence time in the mantle, allowing partial melting of the slab. Foden et al. (2018) also suggested that the mantle wedge peridotite in longer-lived and therefore colder subduction zones remained trapped in the sub-arc mantle by convective 'Richter rolls' (Davies et al. 2016), subjecting the same mantle to continual melt-extraction and fluid ingress, which may have been partially kinetic in nature (see also Zhao et al. 2012), resulting in isotopically light arc 
673 convecting mantle, Zhang et al. (2019) propose that redox-unbuffered melting of arc sources may 674 account for their lighter composition than MORB, yet this does not address the very light isotope 675 signatures observed in magmas from high $\phi$ arcs such as Kamchatka and Samoa.

\section{5.1.2. Differentiation}

677 Magmatic differentiation comprises the range of processes involving, but not limited to, fractional 678 crystallisation, crustal assimilation, fluid exsolution, Soret diffusion and vapour-phase degassing, all of 679 which have the potential to fractionate iron isotopes by mass transfer.

680 The earliest concerted effort to study the effect of magmatic differentiation on iron isotope fractionation 681 was that of Poitrasson and Freydier (2005), who analysed a collection of granites including peralkaline, 682 metaluminous and peraluminous varieties, broadly corresponding to A-, I- and S-type magmas, 683 respectively (Chappell and White 1974; Frost and Frost 2010). These granitic rocks recorded a near684 exponential increase in $\delta^{57} \mathrm{Fe}$ with falling $\mathrm{MgO}$ (below $1 \mathrm{wt}$ \%) or rising $\mathrm{SiO}_{2}$ (above $70 \mathrm{wt}$ \%) contents 685 (their Figs. 5 and 6) relative to the 'mean mafic earth' value of $\delta^{57} \mathrm{Fe}=+0.10 \pm 0.03 \%$ reaching +0.59 $686 \pm 0.03 \%$ (Poitrasson and Freydier 2005). In order to explain this monotonic increase, Poitrasson and 687 Freydier (2005) appealed to the exsolution of $\mathrm{Fe}^{2+}$-rich fluids that transported isotopically light iron. A 688 similar trend was observed by Schoenberg and von Blanckenburg (2006), who cited that additional 689 constraints were required to explain the isotopic relationship with $\mathrm{SiO}_{2}$ content. A fluid-exsolution 690 hypothesis was extended further by (Heimann et al. 2008), who, compiling much of the data available 691 to date (Fig. 9), confirmed the trend of Poitrasson and Freydier (2005) in which silicic igneous rocks 692 exhibited strong positive deviations from mafic igneous rocks above 70 wt. \% $\mathrm{SiO}_{2}$. These authors considered that the lack of correlation of iron isotope composition with incompatible element concentrations (which can be inverted to yield the fraction of melt remaining) argued against the role of fractional crystallisation in determining iron isotope compositions. The observed inverse correlation between $\mathrm{Zr} / \mathrm{Hf}$ and $\delta^{57} \mathrm{Fe}$ was taken as evidence for the effect of fluid exsolution, as Heimann et al. (2008) asserted that these trace elements remain little-affected by crystal fractionation (but see Linnen and Keppler 2002). In these highly differentiated rocks, most of the iron is contained in Fe-Ti oxides (specifically magnetite in oxidised granites and rhyolites), and therefore should retain the heavy isotopes, where Heimann et al. (2008) modelled $\Delta^{57} \mathrm{Fe}_{\text {mag-fluid }}$ between $\approx+0.45 \%$ at $700^{\circ} \mathrm{C}$ and $\approx$ $+0.75 \%$ at $500^{\circ} \mathrm{C}$. Because the solubility of $\mathrm{FeCl}_{2}$ decreases with temperature and isotopic fractionation is proportional to $1 / \mathrm{T}^{2}$, the more fractionated granites should preserve the heaviest iron isotope compositions.

Contemporaneously, Teng et al. (2008) and Schuessler et al. (2009) published two studies showing unequivocal evidence for the role of crystal-liquid fractionation in controlling iron isotope variations in differentiating magmatic systems. Whole rocks from the Kilauea Iki lava lake, Hawai'i, record 
in olivine cumulates to $+0.3 \%$ in evolved basaltic samples (Teng et al. 2008). Importantly, isotopic fractionation is observed below 70 wt. $\% \mathrm{SiO}_{2}$, in contrast to other differentiating magmatic systems. This variation broadly correlates with the $\mathrm{Fe}^{3+} / \sum \mathrm{Fe}$ content of the whole rock, and, more precisely, reflects the incorporation of isotopically light iron into the ${ }^{\mathrm{VI}} \mathrm{Fe}^{2+}$ sites of olivine relative to the residual melt, fit with a fractionation factor $10^{3} \ln ^{57 / 54} \mathrm{Fe} \alpha_{\text {ol-melt }}=-0.20 \pm 0.10 \%$. Unlike at Kilaeua Iki, isotopic fractionation at the Hekla volcano, Iceland, occurs only around $70 \mathrm{wt} . \% \mathrm{SiO}_{2}$, in line with earlier studies (Schuessler et al. 2009). These authors rejected the hypothesis of fluid exsolution as the cause for this variation, based on the constancy of the isotopes of $\mathrm{Li}$, an element even more fluid-mobile than iron, in the same rocks. Instead, they argued for crystallisation of Ti-rich titanomagnetite, which crystallises as Mag $_{35}$ at Hekla (Baldridge et al. 1973), in elevating the iron isotope composition in evolved rocks.

The absence of iron isotope fractionation below $70 \mathrm{wt} . \% \mathrm{SiO}_{2}$, except for the differentiating sequence of basalts at Kilauea Iki behoved an explanation. The Red Hill intrusion, southern Tasmania, exhibits a vertical continuum of compositions created by in situ fractional crystallisation of a single injection of magma in a closed system (Sossi et al. 2012). Much like the Kilauea Iki lava lake, the iron isotope composition of dolerites from Red Hill increased in $\delta^{57} \mathrm{Fe}$ at high $\mathrm{MgO}$ contents, before reaching a maximum near $+0.30 \%$ and declining following the crystallisation of magnetite $\left(\mathrm{Mag}_{95}\right)$, an effect that had been expected, but never observed, on the basis of experimental constraints (Shahar et al. 2008). Thus, iron isotopic evolution for the tholeiitic series mirrored that followed by the liquid line of descent on an AFM (Alkalis-FeO-MgO) diagram, and Sossi et al. (2012) were able to derive fractionation factors; $\Delta^{57} \mathrm{Fe}_{\text {cpx-melt }}=-0.25 \times 10^{6} / \mathrm{T}^{2}$ and $\Delta^{57} \mathrm{Fe}_{\text {mag-melt }}=+0.20 \times 10^{6} / \mathrm{T}^{2}$. These authors also pointed out that the differing behaviour of Kilaeua Iki and Red Hill on one hand and Hekla on the other could be attributed to the extent to which the differentiating system remained open to oxygen exchange (Fig. 10). Systems that are closed to oxygen exchange, which may be imposed by the formation of chilled margins, have only a finite oxygen budget. Therefore, the early crystallisation $\mathrm{Fe}^{2+}$-rich phases increases the $\mathrm{Fe}^{3+} / \sum \mathrm{Fe}$ and $\delta^{57} \mathrm{Fe}$ of the melt, prior to the crystallisation of magnetite-rich titanomagnetite, whose high $\mathrm{Fe}^{3+} / \sum \mathrm{Fe}$ ratio and hence $\delta^{57} \mathrm{Fe}$ is higher than that of the melt. By contrast, systems open to $\mathrm{O}_{2}$ exchange are buffered at values near FMQ, potentially by chemical and mass exchange with surrounding wall rocks (Carmichael 1967). Here, the $\mathrm{Fe}^{3+} / \sum \mathrm{Fe}$ of the melt and minerals remains similar, and they precipitate Ti-rich titanomagnetite, with potentially lower $\mathrm{Fe}^{3+} / \sum \mathrm{Fe}$ than the melt, causing an increase in the iron isotope composition of the residual melt.

Studies of layered intrusions reveal more complex histories that involve the introduction of several pulses of magma and crystal accumulation that blurs the isotopic signal of the evolving melt(s). However, the conclusion from these studies is that magmatic differentiation does not induce significant isotopic fractionation in the bulk rocks (Chen et al. 2014; Liu et al. 2014; Bilenker et al. 2017), notwithstanding the fact that the individual minerals comprising these rocks can be strongly fractionated. Isotopic fractionation generally occurs in the sequence magnetite $>$ clinopyroxene $>$ 
olivine $>$ ilmenite, in broad agreement with the hierarchy depicted in section 4.1. Equilibration temperatures of ilmenite-magnetite pairs suggest slow cooling as anticipated for intrusive magmas, and point to sub-solidus re-equilibration as the cause for these disparate isotopic signatures, thereby leaving the composition of the whole rock unaffected.

The uniformly heavy iron isotope composition of silicic melts also has its origin in the increased bond strength of iron in these highly polymerised, alkali-rich compositions (section 4.2.), as suggested by Schuessler et al. (2009) and Sossi et al. (2012). This behaviour was conclusively illustrated in the combined NRIXS-XANES study of Dauphas et al. (2014), which showed an increase in Fe-O force constants of felsic melts relative to mafic and intermediate compositions at a given $\mathrm{Fe}^{3+} / \sum \mathrm{Fe}$ (see section 4.2.). Foden et al. (2015), upon analysing 42 A-, I- and S-type granites, and compiling literature data, found that only the A-type granites, especially the peralkaline ones, that form from protracted crystallisation of basaltic magma (Turner et al. 1992) exhibited heavy iron isotope compositions. As these granites are typically reduced and $\mathrm{H}_{2} \mathrm{O}$ - and volatile-poor, their heavy compositions likely reflect extensive crystal-liquid segregation rather than fluid exsolution. More reduced, ilmenite-bearing S-type granites also display a similar isotopic evolution, whereas more oxidised, magnetite-series I-type granites never reach heavy iron isotope compositions, likely due to the combined effect of isotopically light olivine and heavy magnetite in cancelling each other out. This behaviour is evident in evolving magmatic rocks from the Anatahan volcano of the Marianas arc (Williams et al. 2018), in which the effect of magnetite crystallisation is less pronounced than at Red Hill (a change in $\delta^{57} \mathrm{Fe}$ of $\approx 0.15 \%$ ) after displaying mildly rising iron isotopic values prior to this point. The iron isotopic evolution then increases towards heavier values at very low $\mathrm{MgO}$ contents below $2 \mathrm{wt} . \%$, as per other siliceous igneous rocks.

Within this framework, recent years have seen a flurry of studies focusing on better understanding the nature of inter-mineral and mineral-melt fractionation in evolved magmatic systems (Du et al. 2017; He et al. 2017; Wu et al. 2017; Xia et al. 2017; Li et al. 2019). These studies argue for the predominant role of fractional crystallisation in producing the heavy $\delta^{57} \mathrm{Fe}$ values of high silica igneous rocks, by a combination of the crystallisation of Ti-rich titanomagnetite and increasing Fe-O bond strength in highly silicic melts with high total alkali/alkaline earth cation ratios (Du et al. 2017; Wu et al. 2017), with residual garnet contributing in peraluminous compositions (He et al. 2017). Noteworthy is the very heavy isotopic composition of plagioclase (Fig. 11), which attests to the preferential incorporation of ferric iron into its structure, as expected on thermodynamic grounds (Lundgaard and Tegner 2004). However, the proportion of total iron hosted in plagioclase is so low so as to be unimportant.

\subsection{Fluid transfer from mantle to crust}

High-pressure (HP) metamorphic ophiolites (meta-ophiolites) returned from former subduction zones 
2002). They constitute an alternative and complementary way to arc magmas to study the isotopic composition and redox state of the fluids released during slab dehydration and devolatilisation at depth. This is of particular importance for establishing the mass balance of key redox-sensitive elements, such as iron, in subduction zones. However, direct constraints on the redox state and the isotopic evolution of $\mathrm{Fe}$ in oceanic lithosphere during subduction remain challenging and the constraints sparse.

\subsubsection{Altered oceanic lithosphere}

The subducting slab consists of ultramafic oceanic mantle, the mafic oceanic crust and their sedimentary cover, all of which undergo seafloor hydrothermal alteration prior to subduction. In the ultramafic parts, this alteration is manifest in the oxidation of primary $\mathrm{Fe}^{2+}$-bearing phases, such as olivine, pyroxenes, to form $\mathrm{Fe}^{3+}$-bearing phases, namely magnetite at high temperature or $\mathrm{Fe}^{3+}$-bearing serpentine at low temperatures (Andreani et al. 2013; Klein et al. 2014; Bonnemains et al. 2016). All abyssal peridotites are variably- to highly serpentinised (Mével 2003) and therefore display high $\mathrm{Fe}^{3+} / \Sigma \mathrm{Fe}(0.58 \pm 0.03 \%$, 2SE, $n=111$; Andreani et al., 2013, 2014; Paulick et al., 2006). However, their iron contents and isotopic compositions are relatively constant, with the exception of peridotites affected by hydrothermal activity (e.g., the Rainbow hydrothermal site) where Fe mobility and therefore isotopic fractionation can be enhanced by the circulation of sulfur-bearing fluids (e.g., Severmann et al., 2004; Debret et al., 2018a). They range from $-0.18 \pm 0.03 \%$ to $0.10 \pm 0.06 \%$ (Craddock et al., 2013 - unweathered samples; Debret et al., 2016; Debret et al., 2018a - non-mineralised samples) with a mean value, -0.03 $\pm 0.03 \%$ ( $2 \mathrm{SE}, n=32$ ), indistinguishable from that of orogenic lherzolites (section 5.1.). Although some variations have been observed among different sites; for example the South West Indian $(0.00 \pm$ $0.03 \%)$ and Gakkel ridge $(0.01 \pm 0.02 \%)$ samples display higher $\delta^{57} \mathrm{Fe}$ values relative to Mid-Atlantic Ridge Kane $(-0.13 \pm 0.02 \%)$ and Rainbow $(-0.05 \pm 0.05 \%)$ samples. This difference has been attributed to melting processes occurring prior to oceanic lithosphere alteration (Debret et al., 2018a). Despite large equilibrium isotope fractionation between $\mathrm{Fe}^{3+}$ and $\mathrm{Fe}^{2+}$ aqueous species and minerals (see section 4.3), these observations suggest that the conversion of peridotites to serpentinites occurs without significant loss or gain of Fe, producing little net change in their Fe isotope compositions.

Relative to fresh oceanic basalts, seafloor-altered basalts record larger variations of $\delta^{57} \mathrm{Fe}(-2.49 \% \mathrm{~s} \leq$ $\delta^{57} \mathrm{Fe} \leq+2.05 \%$; Rouxel et al., 2003), attributed to crystallisation of secondary Fe-bearing minerals at low temperature (Rouxel et al., 2003). Indeed, the interaction of mafic rocks with seawater results in oxidation from $\mathrm{Fe}^{2+}$ to $\mathrm{Fe}^{3+}$ through seawater sulfate reduction at high temperature $\left(200-350^{\circ} \mathrm{C}\right.$; Shanks et al., 1981) and hydrolysis at low temperature $\left(<150^{\circ} \mathrm{C}\right.$; Bach and Edwards, 2003). The limiting factor for the progress of these reactions is the amount of available reacting seawater (water-rock ratio). Their $\mathrm{Fe}^{3+} / \Sigma \mathrm{Fe}$ is therefore expected to be highest in the uppermost mafic crust (from seafloor to depth of about $200 \mathrm{~m}$ ) where permeability is highest. However, the relatively low mean $\mathrm{Fe}^{3+} / \Sigma \mathrm{Fe}(0.22 \pm 0.08)$ of hydrothermally-altered mafic rocks suggests they largely escape oxidation (Lécuyer and Ricard 
814 1999). Similarly, highly fractionated $\delta^{57} \mathrm{Fe}$ values in mafic rocks may therefore be restricted to the 815 uppermost crust. Indeed, oceanic mafic rocks show a limited range of Fe isotope compositions; in 816 ophiolite sections $\left(+0.18 \pm 0.08 \leq \delta^{57} \mathrm{Fe}(\%) \leq+0.43 \pm 0.11\right.$; Inglis et al., 2017) or at mid-oceanic ridges $817 \quad\left(-0.07 \leq \delta^{57} \mathrm{Fe}(\%) \leq 0.33\right.$; Beard et al., 2003, Nebel et al., 2013, Teng et al., 2013, Weyer and Ionov, 818 2007, Williams et al., 2009). Thus, there is no clear evidence of any significant or consistent leaching 819 or addition of iron in metabasites during hydrothermal alteration at depth. 5.2.2. Subducted oceanic lithosphere

The subduction of oceanic lithosphere and overlying sediments initiates a continuum of metamorphic reactions and dehydration/rehydration events between the downgoing slab (Schmidt and Poli, 1998), the slab-mantle wedge interface and/or the mantle wedge, which are strongly controlled by intensive variables, such as temperature, pressure and oxygen fugacity $\left(f \mathrm{O}_{2}\right)$, and the initial composition and mineralogy of the rocks (e.g., Debret \& Sverjensky, 2017; Evans et al., 2017). For a given lithology, the metamorphic evolution is therefore not unique and may vary according to the considered setting. We report here some of the main observations on Fe mobility and redox state in metamorphic lithologies composing meta-ophiolites.

Metamorphic ultramafic rocks outcropping in mountain ranges are often highly deformed and recrystallised into antigorite (high P-T variety of serpentine) and metamorphic olivine during prograde metamorphism (e.g., Trommsdorff et al. 1998; Hermann et al. 2000; Padron-Navarta et al. 2011; Scambelluri et al. 2014; Kempf and Hermann 2018). The recrystallisation of slab serpentinites during subduction results in a net decrease of magnetite mode and $\mathrm{Fe}^{3+} / \Sigma \mathrm{Fe}$ (Debret et al., 2014, 2015; Merkulova et al., 2017). In addition, observations of hematite-magnetite assemblages in dehydrated serpentinites (Debret et al., 2015) suggest high $f \mathrm{O}_{2}(\Delta \mathrm{FMQ}+1$ to +5$)$, during antigorite breakdown in subduction zones, compatible with the release of oxidised $\mathrm{S}$ and $\mathrm{C}$ in slab-derived fluids (Debret \& Sverjensky, 2017). Fluid loss is manifest as an increase in subducted serpentinite $\delta^{57} \mathrm{Fe}$ values, which range from $0.00 \pm 0.10 \%$ to $0.21 \pm 0.10 \%$ (Debret et al., 2016). The negative correlation between $\delta^{57} \mathrm{Fe}$ and $\mathrm{Fe}^{3+} / \Sigma \mathrm{Fe}$ of bulk serpentinites provides direct evidence for the release of Fe-bearing fluids during serpentinite devolatilisation in subduction zones (Fig. 12; Debret et al., 2016). Such a correlation is consistent with the release of sulfate-rich and/or hypersaline fluids, which preferentially complex isotopically light $\mathrm{Fe}$ in the form of $\mathrm{Fe}^{2+}-\mathrm{SO}_{\mathrm{x}}$ or $\mathrm{Fe}^{2+}{ }_{-} \mathrm{Cl}_{2}$ species, during ultramafic rock devolatilisation. No such correlation is observed in eclogitic rocks from meta-ophiolites, suggesting limited Fe mobility during their dehydration, and their compositions likely reflect protolith variations instead (El Korh et al. 2017; Inglis et al. 2017). In accord with these observations, Huang et al. (2019) report typical basaltic values for eclogites from the Dabie Sulu orogeny, with $-0.01 \pm 0.10 \%$ to $+0.15 \pm 0.04 \%(n=9)$,

847 however, they are associated with oxidised, omphacite-epidote veins inferred to have been formed from 848 the breakdown of lawsonite ( \pm phengite). These veins have elevated $\mathrm{Fe}^{3+} / \Sigma \mathrm{Fe}(\approx 0.6-0.9)$ with respect 
849 to the adjacent eclogite $(\approx 0.3-0.5)$ and, consequently higher $\delta^{57} \mathrm{Fe}$, from $0.09 \pm 0.06 \%$ to $0.32 \pm 0.05$

$850 \%$ (Huang et al. 2019). Though these veins are concluded to have been locally-derived from the 851 proximal eclogites on the strength of their similar Sr- and $\mathrm{Nd}$-isotope compositions, they could only 852 have constituted a volumetrically minor fraction of the eclogite source rocks in order to leave their iron 853 isotope compositions unperturbed.

854 Analyses of metasedimentary rocks in meta-ophiolites are rather sporadic in the literature and show a 855 limited range of $\delta^{57} \mathrm{Fe}$, from $0.08 \pm 0.03 \%$ to $0.17 \pm 0.02 \%$ (Inglis et al., 2017). Nebel et al. (2015) 856 analysed a series of currently subducting sediments sampled from the Banda arc whose $\delta^{57} \mathrm{Fe}$ is between $+0.10 \pm 0.07$ to $+0.25 \pm 0.02 \%$ with a mean of $0.17 \pm 0.03 \%$ ( $2 \mathrm{SE}, n=9)$, without any co-variation between $\delta^{57} \mathrm{Fe}$ and detrital element proxies or radiogenic isotope compositions or total organic carbon contents. Siderite $\left(\mathrm{FeCO}_{3}\right)$ and ankerite $\left(\mathrm{Ca}(\mathrm{Fe}, \mathrm{Mg}, \mathrm{Mn})\left(\mathrm{CO}_{3}\right)_{2}\right)$ are the most common Fe-bearing carbonates occurring in seafloor sediments. Both phases are expected to preferentially incorporate light iron relative to olivine (Polyakov \& Mineev, 2000) and can display highly fractionated $\delta^{57} \mathrm{Fe}$ values down to $-2.94 \pm 0.03 \%$ in sediments (e.g., Johnson et al. 2008). These minerals are also particularly soluble in fluids emanating at temperatures ranging from 200 to $300{ }^{\circ} \mathrm{C}$ during shallow subduction (Milesi et al. 2015) and their dissolution would contribute to the formation of carbonate-bearing fluids with a light $\mathrm{Fe}$ isotope signature. Consequently, investigations of carbonated serpentinites from blueschist terrains show that the transfer of carbon-bearing fluids from metasediments to serpentinite can contribute to a strong decrease of $\delta^{57} \mathrm{Fe}$ of serpentinite, down to $-0.40 \%$ (Debret et al., 2018b). Although the exact nature of Fe complexation in sediment-derived fluids is poorly constrained, this observation further corroborates the release of isotopically light fluids during sediment decarbonation and dehydration in subduction zones.

5.2.3. Iron bearing fluids transferred to the mantle wedge

Most studies of meta-ophiolites suggest release of isotopically light Fe in slab-derived fluids during subduction, consistent with the transport of iron with chlorine, sulfate and/or carbonate, as these ligands preferentially complex light $\mathrm{Fe}$ with respect to $\mathrm{Fe}^{3+}$-rich antigorite and magnetite (e.g., see section 4.3., Fujii et al., 2014; Hill et al., 2010). Although the vector of fractionation is correct, it remains unknown whether or not enough $\mathrm{Fe}$ can be mobilised in slab-derived fluids to significantly modify the $\delta^{57} \mathrm{Fe}$ of mantle wedge peridotites to produce the light iron isotope composition of arc magmas (Foden et al. 2018).

Polyphase inclusions trapped in high pressure minerals represent the fluid released at high pressure and temperature during the devolatilisation of the subducting lithosphere in subduction zones. Scambelluri et al. (2015) showed that these olivine-hosted HP-fluids have variable FeO contents from 0.17 to 2.13 $\mathrm{wt} \%$ (assuming $\sum \mathrm{Fe}$ as $\mathrm{FeO}$ ), in which $\mathrm{Cl}$ is often associated with $\mathrm{Fe}$, as inferred from solubility measurements and thermodynamic calculations (see section 4.3.). In addition, the presence of sulfide 
884 phases that are not stable in pristine or altered mantle rocks indicates the mobilisation of sulfur 885 concomitant with chlorine and iron. These authors also report the existence of magnesite in inclusions 886 from chlorite harzburgite, providing compelling evidence of carbon mobilisation in the meta-peridotite 887 dehydration fluid.

888 The interaction of slab-derived fluids during their migration through the slab/mantle interface and the mantle wedge may modify their isotopic signature. In order to test how faithfully this fluid signature is transferred to the mantle wedge (i.e., during subduction), Debret et al. (2018b) analysed metamorphic gem olivines in veins from the Sapat complex, part of the sub-arc mantle of the Kohistan-Ladakh Arc. The vein-forming minerals crystallised from a fluid that migrated through the fore-arc mantle, and display light $\delta^{57} \mathrm{Fe}$ values $(-0.13 \pm 0.13 \%$ to $-0.54 \pm 0.14 \%$ o) relative to that of mantle olivine (e.g., San Carlos olivine $\delta^{57} \mathrm{Fe}$ has $\approx+0.02 \pm 0.05 \%$; Sossi et al., 2015) supporting the hypothesis that they crystallised through reaction with an isotopically fractionated fluid. Similarly, Turner et al. (2018) reported sub-arc mantle xenoliths with light $\delta^{57} \mathrm{Fe}$ (from +0.03 to $-0.46 \%$ ) relative to mantle peridotites. Such values are too fractionated to result solely from partial melting and require slab fluid addition and/or diffusive effects that produce light values. This is confirmed by the correlation between $\delta^{57} \mathrm{Fe}$ and $U / T h$ ratios in these sub-arc xenoliths. Although not all sub-arc peridotites show such isotopically light values (section 5.1.1.), these observations provide empirical evidence for the transfer of isotopically light $\mathrm{Fe}$ across subduction zones, in which Fe can be complexed by chlorine or sulfate or carbonate anions. Existing models (Huang et al. 2019) suggest, given the composition of polyphase inclusions (Scambelluri et al. 2015) and inferred iron isotope fractionation factors between olivine and fluids (Debret et al. 2018), that $30-40 \%$ fluid addition to the mantle wedge would be required to shift their iron isotope compositions to sufficiently light values observed in some arc basalts (- $0.15 \%$; Foden et al. 2018), but this increases to unrealistically high values for sub-arc mantle xenoliths with compositions as low as $-0.46 \%$ (Turner et al. 2018). The predominant uncertainties with such models remain (i) the fraction of fluid permitted to metasomatise the mantle wedge, (ii) its iron content and iron isotope composition (iii) the degree of disequilibrium during fluid-rock interaction and (iv) the nature and identity of the Fe-bearing fluid species. Determining the dominant Fe-bearing species will require experimental work that can produce thermodynamic data for these species at the pressures, temperatures and compositions of interest.

\section{6.0. Conclusion}

914 At the high temperature conditions relevant to the formation of igneous and metamorphic rocks, the 915 differences in the ground-state vibrational frequencies of isotopic substitutions, a quantum mechanical 916 phenomenon, control isotope partitioning between two phases. These frequencies are in turn determined 917 by the bonding environment of iron; where higher redox state and lower co-ordination number tends to 918 favour the heavier isotopes. Similarly, a reduction in partial molar volume of the iron-bearing site in a 919 condensed phase due to either increasing pressure and/or a transition to a low spin electronic 
920 configuration engenders bond contraction and strengthening, also concentrating the heavier isotopes.

921 The role of changing redox state and co-ordination environment in modifying iron force constants is

922 highlighted, particularly along mineral solid solutions, magmatic liquid compositional series (basalt to

923 rhyolite) and for different ligand identities and complexation stoichiometries in aqueous fluids.

924 Partial melting in the Earth's upper mantle results in small $(\approx+0.05 \%)$ iron isotopic enrichment in the

925 liquid relative to its source because isotopically-heavy, ferric iron is preferentially concentrated in the

926 melt with respect to lighter ferrous iron, in addition to its slightly lower mean co-ordination number in

927 silicate liquids relative to minerals. The difference between the melt and its residue decreases with

928 higher degrees of melting and in more reduced sources. Contrastingly, the degree of iron isotopic

929 enrichment in the melt is enhanced in some ocean island basalts due to the presence of heavy isotope-

930 enriched mafic, garnet-bearing components with respect to mid-ocean ridge basalts. Arc magmas are,

931 on average, lighter still, and have iron isotope compositions that are inversely correlative with the $i$ ) age

932 of the subducting slab and ii) its downgoing velocity. The mechanisms that contribute to this isotopic

933 signature may include continued episodes of light, fluid-fluxed melting in stationary sub-arc mantle that

934 are continuously depleted with time in mature subduction zones. However, understanding the relative

935 contribution of each process requires concerted experimental, natural and spectroscopic work to

936 determine the budget, speciation and transport of iron in subduction zones.

937 Magmatic rocks show a tendency towards heavy isotope-enriched compositions with increasing

938 differentiation; however, the conditions under which these liquids cool and crystallise controls their

939 subsequent evolution. Isotopic equilibria between minerals and melt play a predominant role in

940 determining their liquid line of descent; conditions closed to $\mathrm{O}_{2}$ exchange result in heavy isotope

941 enrichment in mafic tholeiitic systems, whereas systems open $\mathrm{O}_{2}$ exchange (typically calc-alkaline

942 magmas in arc environments) exhibit little change in their iron isotope composition prior to $\approx 65-70 \%$

$943 \mathrm{SiO}_{2}$. The uniformly heavy iron isotope composition of granites above this value stems from a

944 strengthening of $\mathrm{Fe}-\mathrm{O}$ bonds in alkali-rich siliceous melts in tandem with crystallisation of $\mathrm{Fe}^{2+}$-bearing

945 phases. Because A-type granites undergo more extensive crystal fractionation than do S- and

946 particularly I-types, they tend to have the heaviest isotopic compositions, while the $\mathrm{Fe}^{3+}$-rich mineral

947 assemblage of I-type granites limits heavy isotopic enrichment.

948 Metamorphism accompanying cooling of the oceanic lithosphere and its hydration at mid-oceanic

949 ridges imparts surprisingly little- to no iron isotopic fractionation at the lithospheric scale, whereas local

950 reactions in the uppermost mafic crust or nearby hydrothermal areas (e.g., Rainbow hydrothermal site)

951 show evidence for iron mobility relative to fresh basalts or peridotites. The analyses of mafic rocks in

952 high pressure meta-ophiolites appear to record primary magmatic signatures and have imprints inherited

953 from prior partial melting episodes. In contrast, sedimentary and ultramafic rocks show progressively

954 heavier iron isotope compositions with increasing metamorphic grade, consistent with the loss of $\mathrm{Fe}^{2+}$

955 bearing species with an isotopically light signature, in which iron is likely complexed by chlorides or

956 oxidised ligands (i.e., sulfate or carbonate). Whether iron is sufficiently concentrated in these fluids to

957 influence the iron isotope composition of the sub-arc mantle remains an area of research. 


\section{Acknowledgements}

959 PAS was supported by the European Research Council under the H2020 framework program/ERC grant

960 agreement \#637503 (PRISTINE) at IPGP and by an SNF Ambizione Fellowship (\#180025) at ETH

961 Zürich. We thank Marc Blanchard and an anonymous reviewer for their thoughtful and constructive 962 reviews. 


\section{References}

964

965

966

967

968

969

970

971

972

973

974

975

976

977

978

979

980

981

982

983

984

985

986

987

988

989

990

991

992

993

994

995

996

997

998

999

1000

1001

1002

1003

1004

1005

1006

Andreani M, Escartin J, Delacour A, et al (2014) Tectonic structure, lithology, and hydrothermal signature of the rainbow massif (Mid-Atlantic Ridge $36^{\circ} 14^{\prime} \mathrm{N}$ ). Geochemistry, Geophys Geosystems 15:3543-3571. doi: 10.1002/2014GC005269

Andreani M, Muñoz M, Marcaillou C, Delacour A (2013) $\mu$ XANES study of iron redox state in serpentine during oceanic serpentinization. Lithos 178:70-83. doi: 10.1016/j.lithos.2013.04.008

Arató R, Audétat A (2019) Magnetite - silicate melt oxybarometry. (This volume).

Armstrong K, Frost DJ, McCammon CA, et al (2017) The Effect of Pressure on Iron Speciation in Silicate Melts at a Fixed Oxygen Fugacity: The Possibility of a Redox Profile Through a Terrestrial Magma Ocean. AGU Fall Meeting, \#MR54A-04

Asimow PD, Hirschmann MM, Stolper EM (1997) An analysis of variations in isentropic melt productivity. Philos Trans R Soc A Math Phys Eng Sci 355:255-281. doi: 10.1098/rsta.1997.0009

Ayers JC, Dittmer SK, Layne GD (1997) Partitioning of elements between peridotite and $\mathrm{H}_{2} \mathrm{O}$ at 2.0 $3.0 \mathrm{GPa}$ and $900-1100^{\circ} \mathrm{C}$, and application to models of subduction zone processes. Earth Planet Sci Lett 150:381-398. doi: 10.2134/jeq2005.0109

Bach W, Edwards KJ (2003) Iron and sulfide oxidation within the basaltic ocean crust: Implications for chemolithoautotrophic microbial biomass production. Geochim Cosmochim Acta 67:38713887. doi: 10.1016/S0016-7037(03)00304-1

Badro J, Fiquet G, Guyot F, et al (2003) Iron partitioning in Earth's mantle: toward a deep lower mantle discontinuity. Science 300:789-791. doi: 10.1126/science.1081311

Badro J, Rueff J-P, Vankó G, et al (2004) Electronic Transitions in Perovskite: Possible Nonconvecting Layers in the Lower Mantle. Science 305:383-386. doi: $10.1126 /$ science. 1098840

Baldridge WS, McGetchin TR, Frey FA, Jarosewich E (1973) Magmatic evolution of Hekla, Iceland. Contrib to Mineral Petrol 42:245-258. doi: 10.1007/BF00371589

Barnes SJ, Roeder PL (2001) The Range of Spinel Compositions in Terrestrial Mafic and Ultramafic Rocks. J Petrol 42:2279-2302.

Beard BL, Johnson CM, Skulan JL, et al (2003a) Application of Fe isotopes to tracing the geochemical and biological cycling of Fe. Chem Geol 195:87-117. doi: 10.1016/S00092541(02)00390-X

Beard BL, Johnson CM, Von Damm KL, Poulson RL (2003b) Iron isotope constraints on Fe cycling and mass balance in oxygenated Earth oceans. Geology 31:629-632. doi: 10.1130/00917613(2003)031<0629:IICOFC $>2.0 . \mathrm{CO} ; 2$

Bénard A, Woodland AB, Arculus RJ, et al (2018) Variation in sub-arc mantle oxygen fugacity during partial melting recorded in refractory peridotite xenoliths from the West Bismarck Arc. Chem Geol 486:16-30. doi: 10.1016/j.chemgeo.2018.03.004

Berry AJ, Yaxley GM, Woodland AB, Foran GJ (2010) A XANES calibration for determining the oxidation state of iron in mantle garnet. Chem Geol 278:31-37. doi: 10.1016/j.chemgeo.2010.08.019

Berry AJ, Stewart GA, O’Neill HSC, et al (2018) A re-assessment of the oxidation state of iron in MORB glasses. Earth Planet Sci Lett 483:114-123. doi: 10.1016/j.eps1.2017.11.032

Bigeleisen J, Mayer MG (1947) Calculation of Equilibrium Constants for Isotopic Exchange Reactions. J Chem Phys 15:261-267. doi: 10.1063/1.1746492 
Bilenker LD, VanTongeren JA, Lundstrom CC, Simon AC (2017) Iron isotopic evolution during fractional crystallization of the uppermost Bushveld Complex layered mafic intrusion. Geochemistry, Geophys Geosystems 18:2016GC006660. doi: 10.1002/2016GC006679.Received

Blanchard M, Poitrasson F, Méheut M, et al (2009) Iron isotope fractionation between pyrite $\left(\mathrm{FeS}_{2}\right)$, hematite $\left(\mathrm{Fe}_{2} \mathrm{O}_{3}\right)$ and siderite $\left(\mathrm{FeCO}_{3}\right)$ : A first-principles density functional theory study. Geochim Cosmochim Acta 73:6565-6578. doi: 10.1016/j.gca.2009.07.034

Blanchard M, Dauphas N (2019) Oxidation state, coordination, and covalency controls on iron isotopic fractionation in Earth's mantle and crust: Insights from first-principles calculations and NRIXS spectroscopy. (this volume)

Boctor NZ, Popp RK, Frantz JD (1980) Mineral-solution equilibria-IV. Solubilities and the thermodynamic properties of $\mathrm{FeCl}_{2}$ in the system $\mathrm{Fe}_{2} \mathrm{O}_{3}-\mathrm{H}_{2}-\mathrm{H}_{2} \mathrm{O}-\mathrm{HCl}$. Geochim Cosmochim Acta 44:1509-1518.

Bonnemains D, Carlut J, Escarti-n J, et al (2016) Magnetic signatures of serpentinization at ophiolite complexes. Geochemistry, Geophys Geosystems 17:2969-2986. doi: 10.1002/2016GC006321

Borisov A, Behrens H, Holtz F (2017) Effects of strong network modifiers on $\mathrm{Fe}^{3+} / \mathrm{Fe}^{2+}$ in silicate melts: an experimental study. Contrib to Mineral Petrol 172:34. doi: 10.1007/s00410-017-13371

Borisov A, McCammon C (2010) The effect of silica on ferric/ferrous ratio in silicate melts: An experimental study using Mössbauer spectroscopy. Am Mineral 95:545-555. doi: 10.2138/am.2010.3217

Bosi F, Halenius U, Skogby H (2009) Crystal chemistry of the magnetite-ulvospinel series. Am Mineral 94:181-189. doi: 10.2138/am.2009.3002

Bourdon B, Roskosz M, Hin RC (2018) Isotope tracers of core formation. Earth-Science Rev 181:6181. doi: 10.1016/J.EARSCIREV.2018.04.006

Brugger J, Liu W, Etschmann B, et al (2016) A review of the coordination chemistry of hydrothermal systems, or do coordination changes make ore deposits? Chem Geol 447:219-253. doi: 10.1016/j.chemgeo.2016.10.021

Buddington AF, Lindsley DH (1964) Iron-Titanium Oxide Minerals and Synthetic Equivalents. J Petrol 5:310-357. doi: 10.1093/petrology/5.2.310

Burnham CW (1979) Magmas and hydrothermal fluids. In: Barnes HL (ed) Geochemistry of Hydrothermal Ore Deposits, 2nd edn. John Wiley \& Sons, New York, pp 71-136

Cameron M, Sueno S, Prewitt CT, Papike JJ (1973) High-Temperature Crystal Chemistry of Acmite, Diopside, Hedenbergite, Jadeite, Spodumene and Ureyite. Am Mineral 58:594-618.

Candela PA (1989) Magmatic ore-forming fluids: thermodynamic and mass transfer calculations of metal concentrations. In: Whitney JA, J NA (eds) Ore Deposition Associated with Magmas : Soc.Econ.Geol., Reviews in Economic Geology. pp 203-221

Canil D, O’Neill HSC (1996) Distribution of Ferric Iron in some Upper-Mantle Assemblages. J Petrol 37:609-635.

Canil D, O'Neill HSC, Pearson DG, et al (1994) Ferric iron in peridotites and mantle oxidation states. Earth Planet Sci Lett 123:205-220. doi: 10.1016/0012-821X(94)90268-2

Carmichael ISE (1967) The mineralogy of Thingmuli, a Tertiary' volcano in eastern Iceland. Am J Sci 276:309-329.

Carmichael ISE (1991) The redox states of basic and silicic magmas: a reflection of their source 

regions? Contrib to Mineral Petrol 106:129-141. doi: 10.1007/BF00306429

1052

1053

1054

1055

1056

1057

1058

1059

1060

1061

1062

1063

1064

1065

1066

1067

1068

1069

1070

1071

1072

1073

1074

1075

1076

1077

1078

1079

1080

1081

1082

1083

1084

1085

1086

1087

1088

1089

1090

1091

1092

1093

1094

Chappell BW, White AJR (1974) Two contrasting granite types. Pacific Geol 8:173-174.

Chen L-M, Song X-Y, Zhu X-K, et al (2014) Iron isotope fractionation during crystallization and subsolidus re-equilibration: Constraints from the Baima mafic layered intrusion, SW China. Chem Geol 380:97-109. doi: 10.1016/j.chemgeo.2014.04.020

Chou I-M, Eugster HP (1977) Solubility of Magnetite in Supercritical Chloride Solutions. Am J Sci 277:1296-1314.

Craddock PR, Warren JM, Dauphas N (2013) Abyssal peridotites reveal the near-chondritic Fe isotopic composition of the Earth. Earth Planet Sci Lett 365:63-76.

Dauphas N, Craddock PR, Asimow PD, et al (2009) Iron isotopes may reveal the redox conditions of mantle melting from Archean to Present. Earth Planet Sci Lett 288:255-267.

Dauphas N, Roskosz M, Alp EE, et al (2012) A general moment NRIXS approach to the determination of equilibrium $\mathrm{Fe}$ isotopic fractionation factors: Application to goethite and jarosite. Geochim Cosmochim Acta 94:254-275. doi: 10.1016/j.gca.2012.06.013

Dauphas N, Roskosz M, Alp EE, et al (2014) Magma redox and structural controls on iron isotope variations in Earth's mantle and crust. Earth Planet Sci Lett 398:127-140. doi: 10.1016/j.eps1.2014.04.033

Davies DR, Le Voci G, Goes S, et al (2016) The mantle wedge's transient 3-D flow regime and thermal structure. Geochemistry, Geophys Geosystems 17:78-100.

Davis FA, Humayun M, Hirschmann MM, Cooper RS (2013) Experimentally determined mineral/melt partitioning of first-row transition elements (FRTE) during partial melting of peridotite at 3GPa. Geochim Cosmochim Acta 104:232-260. doi: 10.1016/j.gca.2012.11.009

Debret B, Andreani M, Muñoz M, et al (2014) Evolution of Fe redox state in serpentine during subduction. Earth Planet Sci Lett 400:206-218. doi: 10.1016/j.eps1.2014.05.038

Debret B, Beunon H, Mattielli N, Andreani M, Ribeiro Da Costa I, Escartin J (2018a). Ore component mobility, transport and mineralization at mid-oceanic ridges: a stable isotopes ( $\mathrm{Zn}, \mathrm{Cu}$ and $\mathrm{Fe}$ ) study of the Rainbow massif (Mid-Atlantic Ridge $36^{\circ} 14^{\prime} \mathrm{N}$ ). Earth Planet Sci Lett 503:170-180, doi:10.1016/j.eps1.2018.09.009

Debret B, Bolfan-Casanova N, Padrón-Navarta JA, et al (2015) Redox state of iron during highpressure serpentinite dehydration. Contrib to Mineral Petrol 169:1-18. doi: 10.1007/s00410-015$1130-\mathrm{y}$

Debret B, Bouilhol P, Pons ML, Williams H (2018b) Carbonate Transfer during the Onset of Slab Devolatilization: New Insights from Fe and Zn Stable Isotopes. J Petrol 59:1145-1166. doi: 10.1093/petrology/egy057

Debret B, Millet MA, Pons ML, Bouilhol P, Inglis E, Williams H (2016). Isotopic evidence for iron mobility during subduction. Geology 44:215-218.

Debret B, Sverjensky DA (2017) Highly oxidising fluids generated during serpentinite breakdown in subduction zones. Sci Rep 7:1-6. doi: 10.1038/s41598-017-09626-y

Dickenson MP, Hess PC (1986) The structural role and homogeneous redox equilibria of iron in peraluminous, metaluminous and peralkaline silicate melts. Contrib to Mineral Petrol 92:207217.

Ding K, Seyfried WE (1992) Determination of Fe-Cl complexing in the low pressure supercritical region ( $\mathrm{NaCl}$ fluid): Iron solubility constraints on $\mathrm{pH}$ of subseafloor hydrothermal fluids. Geochim Cosmochim Acta 56:3681-3692. doi: 10.1016/0016-7037(92)90161-B 
Du DH, Wang XL, Yang T, et al (2017) Origin of heavy Fe isotope compositions in high-silica igneous rocks: A rhyolite perspective. Geochim Cosmochim Acta 218:58-72. doi: 10.1016/j.gca.2017.09.014

Evans KA, Reddy SM, Tomkins AG, et al (2017) Effects of geodynamic setting on the redox state of fluids released by subducted mantle lithosphere. Lithos 278-281:26-42. doi: 10.1016/j.lithos.2016.12.023

Evans K-A, Tomkins A-G (2011) The relationship between subduction zone redox budget and arc magma fertility. Earth Planet Sci Lett 308:401-409. doi: 10.1016/j.eps1.2011.06.009

Farges F, Lefrère Y, Rossano S, et al (2004) The effect of redox state on the local structural environment of iron in silicate glasses: a combined XAFS spectroscopy, molecular dynamics, and bond valence study. J Non Cryst Solids 344:176-188. doi: 10.1016/j.jnoncrysol.2004.07.050

Fein JB, Hemley JJ, Angelo WMD, et al (1992) Experimental study of iron-chloride complexing in hydrothermal fluids. Geochim Cosmochim Acta 56:3179-3190. doi: 10.1016/00167037(92)90296-U

Foden J, Sossi PA, Nebel O (2018) Controls on the iron isotopic composition of global arc magmas. Earth Planet Sci Lett. doi: 10.1016/j.epsl.2018.04.039

Foden J, Sossi PA, Wawryk CM (2015) Fe isotopes and the contrasting petrogenesis of A-, I- and Stype granite. Lithos 212-215:32-44. doi: 10.1016/j.lithos.2014.10.015

Frost CD, Frost BR (2010) On Ferroan (A-type) Granitoids: their Compositional Variability and Modes of Origin. J Petrol 52:39-53. doi: 10.1093/petrology/egq070

Fujii T, Moynier F, Blichert-Toft J, Albarède F (2014) Density functional theory estimation of isotope fractionation of $\mathrm{Fe}, \mathrm{Ni}, \mathrm{Cu}$, and $\mathrm{Zn}$ among species relevant to geochemical and biological environments. Geochim Cosmochim Acta 140:553-576. doi: 10.1016/j.gca.2014.05.051

Fujino K, Nishio-Hamane D, Seto Y, et al (2012) Spin transition of ferric iron in Al-bearing Mgperovskite up to $200 \mathrm{GPa}$ and its implication for the lower mantle. Earth Planet Sci Lett 317318:407-412. doi: 10.1016/J.EPSL.2011.12.006

Hawthorne FC (1978) The Crystal Chemistry of the Amphiboles. VIII. The Crystal Structure and Site Chemistry of Fluor-Riebeckite. Can Mineral 16:187-194.

$\mathrm{He} \mathrm{Y,} \mathrm{Wu} \mathrm{H,} \mathrm{Ke} \mathrm{S,} \mathrm{et} \mathrm{al} \mathrm{(2017)} \mathrm{Iron} \mathrm{isotopic} \mathrm{compositions} \mathrm{of} \mathrm{adakitic} \mathrm{and} \mathrm{non-adakitic} \mathrm{granitic}$ magmas: Magma compositional control and subtle residual garnet effect. Geochim Cosmochim Acta 203:89-102. doi: 10.1016/j.gca.2017.01.005

Heimann A, Beard BL, Johnson CM (2008) The role of volatile exsolution and sub-solidus fluid/rock interactions in producing high ${ }^{56} \mathrm{Fe} /{ }^{54} \mathrm{Fe}$ ratios in siliceous igneous rocks. Geochim Cosmochim Acta 72:4379-4396. doi: 10.1016/j.gca.2008.06.009

Hermann J, Müntener O, Scambelluri M (2000) The importance of serpentinite mylonites for subduction and exhumation of oceanic crust. Tectonophysics 327:225-238. doi: 10.1016/S00401951(00)00171-2

Hill PS, Schauble E a., Shahar A, et al (2009) Experimental studies of equilibrium iron isotope fractionation in ferric aquo-chloro complexes. Geochim Cosmochim Acta 73:2366-2381. doi: 10.1016/j.gca.2009.01.016

Hill PS, Schauble E a., Young ED (2010) Effects of changing solution chemistry on $\mathrm{Fe}^{3+} / \mathrm{Fe}^{2+}$ isotope fractionation in aqueous $\mathrm{Fe}-\mathrm{Cl}$ solutions. Geochim Cosmochim Acta 74:6669-6689. doi: 10.1016/j.gca.2010.08.038

Hill PS, Schauble EA (2008) Modeling the effects of bond environment on equilibrium iron isotope fractionation in ferric aquo-chloro complexes. Geochim Cosmochim Acta 72:1939-1958. 
Hirschmann MM, Ghiorso MS, Stolper M (1999) Calculation of Peridotite Partial Melting from Thermodynamic Models of Minerals and Melts. II. Isobaric Variations in Melts near the Solidus and owing to Variable Source Composition. J Petrol 40:297-313. doi: 10.1093/petroj/40.2.297

Huang F, Zhang Z, Lundstrom CC, Zhi X (2011) Iron and magnesium isotopic compositions of peridotite xenoliths from Eastern China. Geochim Cosmochim Acta 75:3318-3334. doi: 10.1016/j.gca.2011.03.036

Huang J, Guo S, Jin Q-Z, Huang F (2019) Iron and magneisum isotopic compositions of subductionzone fluids and implications for arc volcanism. Geochim Cosmochim Acta. In press. 10.1016/j.gca.2019.06.020

Inglis EC, Debret B, Burton KW, et al (2017) The behavior of iron and zinc stable isotopes accompanying the subduction of mafic oceanic crust: A case study from Western Alpine ophiolites. Geochemistry, Geophys Geosystems 18:2562-2579. doi: 10.1002/2016GC006735

Jackson JM, Sturhahn W, Shen G, et al (2005a) A synchrotron Mössbauer spectroscopy study of $(\mathrm{Mg}, \mathrm{Fe}) \mathrm{SiO}_{3}$ perovskite up to $120 \mathrm{GPa}$. Am Mineral 90:199-205. doi: 10.2138/am.2005.1633

Jackson WE, Farges F, Yeager M, et al (2005b) Multi-spectroscopic study of Fe(II) in silicate glasses: Implications for the coordination environment of $\mathrm{Fe}(\mathrm{II})$ in silicate melts. Geochim Cosmochim Acta 69:4315-4332. doi: 10.1016/j.gca.2005.01.008

Jayasuriya KD, O’Neill HSC, Berry AJ, Campbell SJ (2004) A Mössbauer study of the oxidation state of Fe in silicate melts. Am Mineral 89:1597-1609.

Johnson CM, Beard BL, Klein C, et al (2008) Iron isotopes constrain biologic and abiologic processes in banded iron formation genesis. Geochim Cosmochim Acta 72:151-169. doi: 10.1016/J.GCA.2007.10.013

Kelley KA, Cottrell E (2009) Water and the Oxidation State of Subduction Zone Magmas. Science 325:605-607. doi: 10.1126/science.1174156

Kempf ED, Hermann J (2018) Hydrogen incorporation and retention in metamorphic olivine during subduction: Implications for the deep water cycle. Geology 46:571-574. doi: 10.1130/G40120.1

Kinzler RJ, Grove TL (1992) Primary Magmas of Mid-Ocean Ridge Basalts 1. Experiments and Methods. J Geophys Res 97:6885-6906.

Kirby SH, Engdahl RE, Denlinger R (1996) Intermediate-Depth Intraslab Earthquakes and Arc Volcanism as Physical Expressions of Crustal and Uppermost Mantle Metamorphism in Subducting Slabs. In: Bebout GE, Scholl DW, Kirby SH, Platt JP (eds) Subduction: Top to Bottom. American Geophysical Union, Washington DC, pp 195-214

Klein F, Bach W, Humphris SE, et al (2014) Magnetite in seafloor serpentinite-Some like it hot. Geology 42:135-138. doi: 10.1130/G35068.1

Knipping JL, Behrens H, Wilke M, et al (2015) Effect of oxygen fugacity on the coordination and oxidation state of iron in alkali bearing silicate melts. Chem Geol 411:143-154. doi: 10.1016/j.chemgeo.2015.07.004

Konter JG, Pietruszka AJ, Hanan BB, et al (2016) Unusual $\delta^{56} \mathrm{Fe}$ values in Samoan rejuvenated lavas generated in the mantle. Earth Planet Sci Lett 450:221-232. doi: 10.1016/j.eps1.2016.06.029

Kress VC, Carmichael ISE (1991) The compressibility of silicate liquids containing $\mathrm{Fe}_{2} \mathrm{O}_{3}$ and the effect of composition, temperature, oxygen fugacity and pressure on their redox states. Contrib to Mineral Petrol 108:82-92. doi: 10.1007/BF00307328

Kwak TAP, Brown WM, Abeysinghe PB, Teong Hing Tan (1986) Fe solubilities in very saline hydrothermal fluids: their relation to zoning in some ore deposits. Econ Geol 81:447-465. doi: 10.2113/gsecongeo.81.2.447 
Lange RA, Carmichael ISE (1987) Densities of $\mathrm{Na}_{2} \mathrm{O}-\mathrm{K}_{2} \mathrm{O}-\mathrm{CaO}-\mathrm{MgO}-\mathrm{FeO}-\mathrm{Fe}_{2} \mathrm{O}_{3}-\mathrm{Al}_{2} \mathrm{O}_{3}-\mathrm{TiO}_{2}-\mathrm{SiO}_{2}$ liquids: New measurements and derived partial molar properties. Geochim Cosmochim Acta 51:2931-2946. doi: 10.1016/0016-7037(87)90368-1

Lécuyer C, Ricard Y (1999) Long-term fluxes and budget of ferric iron: Implication for the redox states of the Earth's mantle and atmosphere. Earth Planet Sci Lett 165:197-211. doi: $10.1016 / \mathrm{S} 0012-821 \mathrm{X}(98) 00267-2$

Lee C-TA, Leeman WP, Canil D, Li Z-XA (2005) Similar V/Sc Systematics in MORB and Arc Basalts: Implications for the Oxygen Fugacities of their Mantle Source Regions. J Petrol 46:2313-2336. doi: 10.1093/petrology/egi056

Li C, Ripley EM (2009) Sulfur contents at sulfide-liquid or anhydrite saturation in silicate melts:Empirical equations and example applications. Econ Geol 104:405-412. doi: 10.2113/gsecongeo.104.3.405

Li J-X, Qin K-Z, Li G-M, et al (2018) Iron isotope fractionation during magmatic-hydrothermal evolution: A case study from the Duolong porphyry $\mathrm{Cu}-\mathrm{Au}$ deposit, Tibet. Geochim Cosmochim Acta 238:1-15. doi: 10.1016/J.GCA.2018.07.008

Li Q-W, Nebel O, Nebel-Jacobsen Y et al (2019) Crustal reworking at convergent margins traced by Fe isotopes in I-type intrusions from the Gangdese arc, Tibetan Plateau. Chem Geol 510:47-55.

Lin J-F, Speziale S, Mao Z, Marquardt H (2013) Effects of the electronic spin transition of iron in lower mantle minerals: implications for deep mantle geophysics and geochemistry. Rev Geophys 51:244-275. doi: 10.1002/rog.20010

Linnen RL, Keppler H (2002) Melt composition control of $\mathrm{Zr} / \mathrm{Hf}$ fractionation in magmatic processes. Geochim Cosmochim Acta 66:3293-3301.

Liu J, Dauphas N, Roskosz M, et al (2017) Iron isotopic fractionation between silicate mantle and metallic core at high pressure. Nat Commun 8:14377 doi: 10.1038/ncomms14377

Liu P-P, Zhou M-F, Luais B, et al (2014) Disequilibrium iron isotopic fractionation during the hightemperature magmatic differentiation of the Baima $\mathrm{Fe}-\mathrm{Ti}$ oxide-bearing mafic intrusion, $\mathrm{SW}$ China. Earth Planet Sci Lett 399:21-29. doi: 10.1016/j.eps1.2014.05.002

Lundgaard KL, Tegner C (2004) Partitioning of ferric and ferrous iron between plagioclase and silicate melt. Contrib to Mineral Petrol 147:470-483. doi: 10.1007/s00410-004-0568-0

Mallmann G, O’Neill HSC (2009) The Crystal/Melt Partitioning of V during Mantle Melting as a Function of Oxygen Fugacity Compared with some other Elements (Al, P, Ca, Sc, Ti, Cr, Fe, Ga, Y, Zr and Nb). J Petrol 50:1765-1794. doi: 10.1093/petrology/egp053

Manning CE (2004) The chemistry of subduction-zone fluids. Earth Planet Sci Lett 223:1-16. doi: 10.1016/j.eps1.2004.04.030

Mathez EA (1984) Influence of degassing on oxidation states of basaltic magmas. Nature 310:371375.

McCammon C (1997) Perovskite as a possible sink for ferric iron in the lower mantle. Nature 387:694-696. doi: 10.1038/42685

McCammon C, Dubrovinsky L, Narygina O, et al (2010) Low-spin $\mathrm{Fe}^{2+}$ in silicate perovskite and a possible layer at the base of the lower mantle. Phys Earth Planet Inter 180:215-221. doi: 10.1016/J.PEPI.2009.10.012

Merkulova M V., Muñoz M, Brunet F, et al (2017) Experimental insight into redox transfer by ironand sulfur-bearing serpentinite dehydration in subduction zones. Earth Planet Sci Lett 479:133143. doi: 10.1016/j.eps1.2017.09.009 
Mével C (2003) Serpentinization of abyssal peridotites at mid-ocean ridges. Comptes Rendus Geosci 335:825-852. doi: 10.1016/j.crte.2003.08.006

Milesi V, Guyot F, Brunet F, et al (2015) Formation of $\mathrm{CO}_{2}, \mathrm{H}_{2}$ and condensed carbon from siderite dissolution in the $200-300^{\circ} \mathrm{C}$ range and at $50 \mathrm{MPa}$. Geochim Cosmochim Acta 154:201-211. doi: $10.1016 /$ j.gca.2015.01.015

Nebel O, Arculus RJ, Sossi PA, et al (2013) Iron isotopic evidence for convective resurfacing of recycled arc-front mantle beneath back-arc basins. Geophys Res Lett 40:5849-5853. doi: 10.1002/2013GL057976

Nebel O, Sossi PA, Bénard A, et al (2015) Redox-variability and controls in subduction zones from an iron-isotope perspective. Earth Planet Sci Lett 432:142-151. doi: 10.1016/j.eps1.2015.09.036

Nebel O, Sossi PA, Foden J et al. (2018) Iron isotope variability in ocean floor lavas and mantle sources in the Lau back-arc basin. Geochim Cosmochim Acta 241:150-163. doi: 10.1016/j.gca.2018.08.046

Nell J, Wood BJ, Mason TO (1989) High-temperature cation distributions in $\mathrm{Fe}_{3} \mathrm{O}_{4}-\mathrm{MgAl}_{2} \mathrm{O}_{4^{-}}$ $\mathrm{MgFe}_{2} \mathrm{O}_{4}-\mathrm{FeAl}_{2} \mathrm{O}_{4}$ spinels from thermopower and conductivity measurement. Am Mineral 74:339-351.

O'Neill HSC, Berry AJ, McCammon CC, et al (2006) An experimental determination of the effect of pressure on the $\mathrm{Fe}^{3+} / \sum \mathrm{Fe}$ ratio of an anhydrous silicate melt to 3.0 GPa. Am Mineral 91:404412. doi: 10.2138/am.2005.1929

O'Neill HSC, Mavrogenes JA (2002) The Sulfide Capacity and the Sulfur Content at Sulfide Saturation of Silicate Melts at $1400^{\circ} \mathrm{C}$ and 1 bar. J Petrol 43:1049-1087.

O'Neill HSC, Navrotsky A (1984) Cation distributions and thermodynamic properties of binary spinel solid solutions. Am Mineral 69:733-753.

Padron-Navarta J a., Lopez Sanchez-Vizcaino V, Garrido CJ, Gomez-Pugnaire MT (2011) Metamorphic Record of High-pressure Dehydration of Antigorite Serpentinite to Chlorite Harzburgite in a Subduction Setting (Cerro del Almirez, Nevado-Filabride Complex, Southern Spain). J Petrol 52:2047-2078. doi: 10.1093/petrology/egr039

Paulick H, Bach W, Godard M, et al (2006) Geochemistry of abyssal peridotites (Mid-Atlantic Ridge, $15^{\circ} 20^{\prime} \mathrm{N}$, ODP Leg 209): Implications for fluid/rock interaction in slow spreading environments. Chem Geol 234:179-210. doi: 10.1016/j.chemgeo.2006.04.011

Pauling L (1929) The Principles Determining the Structure of Complex Ionic Crystals. J Am Chem Soc 51:1010-1026.

Peters BJ, Shahar A, Carlson RW, et al (2019) A sulfide perspective on iron isotope fractionation during ocean island basalt petrogenesis. Geochim Cosmochim Acta 245:59-78. doi: 10.1016/J.GCA.2018.10.015

Petric A, Jacob KT, Alcock CB (1981) Thermodynamic Properties of $\mathrm{Fe}_{3} \mathrm{O}_{4}-\mathrm{FeAl}_{2} \mathrm{O}_{4}$ Spinel Solid Solutions. J Am Ceram Soc 64:632-639. doi: 10.1111/j.1151-2916.1981.tb15860.x

Poitrasson F, Delpech G, Grégoire M (2013) On the iron isotope heterogeneity of lithospheric mantle xenoliths: implications for mantle metasomatism, the origin of basalts and the iron isotope composition of the Earth. Contrib to Mineral Petrol 165:1243-1258. doi: 10.1007/s00410-0130856-7

Poitrasson F, Freydier R (2005) Heavy iron isotope composition of granites determined by high resolution MC-ICP-MS. Chem Geol 222:132-147. doi: 10.1016/j.chemgeo.2005.07.005

Poitrasson F, Halliday AN, Lee D-C, et al (2004) Iron isotope differences between Earth, Moon, Mars and Vesta as possible records of contrasted accretion mechanisms. Earth Planet Sci Lett 
Poli S, Schmidt MW (2002) Petrology of Subducted Slabs. Annu Rev Earth Planet Sci 30:207-235. doi: 10.1146/annurev.earth.30.091201.140550

Polyakov VB (2009) Equilibrium iron isotope fractionation at core-mantle boundary conditions. Science 323:912-4. doi: 10.1126/science.1166329

Polyakov VB, Clayton RN, Horita J, Mineev SD (2007) Equilibrium iron isotope fractionation factors of minerals- Reevaluation from the data of nuclear inelastic resonant X-ray scattering and Mössbauer spectroscopy.pdf. Geochim Cosmochim Acta 71:3833-3846.

Polyakov VB, Kharlashina NN (1994) Effect of pressure on equilibrium isotopic fractionation. Geochim Cosmochim Acta 58:4739-4750.

Polyakov VB, Mineev SD (2000) The use of Mössbauer spectroscopy in stable isotope geochemistry. Geochim Cosmochim Acta 64:849-865.

Poustovetov AA, Roeder PL (2000) The distribution of $\mathrm{Cr}$ between basaltic melt and chromian spinel as an oxygen geobarometer. Can Mineral 39:309-317.

Richards JP (2011) Magmatic to hydrothermal metal fluxes in convergent and collided margins. Ore Geol Rev 40:1-26. doi: 10.1016/j.oregeorev.2011.05.006

Roskosz M, Sio CKI, Dauphas N, Bi W (2015) Spinel - olivine - pyroxene equilibrium iron isotopic fractionation and applications to natural peridotites. 169:184-199. doi: 10.1016/j.gca.2015.07.035

Rouxel O, Dobbek N, Ludden J, Fouquet Y (2003) Iron isotope fractionation during oceanic crust alteration. Chem Geol 202:155-182. doi: 10.1016/j.chemgeo.2003.08.011

Rustad JR, Yin Q-Z (2009) Iron isotope fractionation in the Earth's lower mantle. Nat Geosci 2:514518. doi: $10.1038 /$ ngeo546

Sanchez-Valle C, Hin RC, Testemale D, et al (2017) Stability of oxidized iron species and the redox budget of slab-derived fluids. In: American Geophysical Union, Fall Meeting. p V11D-01

Sanloup C, Drewitt JWE, Konôpková Z, et al (2013) Structural change in molten basalt at deep mantle conditions. Nature 503:104-107. doi: 10.1038/nature12668

Saunier G, Pokrovski GS, Poitrasson F (2011) First experimental determination of iron isotope fractionation between hematite and aqueous solution at hydrothermal conditions. Geochim Cosmochim Acta 75:6629-6654. doi: 10.1016/j.gca.2011.08.028

Scambelluri M, Pettke T, Cannaò E (2015) Fluid-related inclusions in Alpine high-pressure peridotite reveal trace element recycling during subduction-zone dehydration of serpentinized mantle (Cima di Gagnone, Swiss Alps). Earth Planet Sci Lett 429:45-59. doi: 10.1016/j.eps1.2015.07.060

Scambelluri M, Pettke T, Rampone E, et al (2014) Petrology andtrace element budgets of highpressure peridotites indicate subduction dehydration of serpentinized mantle (Cima di Gagnone, Central Alps, Switzerland). J Petrol 55:459-498. doi: 10.1093/petrology/egt068

Schauble E (2004) Applying stable isotope fractionation theory to new systems. Rev Mineral Geochemistry 55:65. doi: 10.2138/gsrmg.55.1.65

Schauble EA, Rossman GR, Taylor HP (2001) Theoretical estimates of equilibrium Fe-isotope fractionations from vibrational spectroscopy. Geochim Cosmochim Acta 65:2487-2497.

Schmidt MW, Poli S (1998) Experimentally based water budgets for dehydrating slabs and consequences for arc magma generation. Earth Planet Sci Lett 163:361-379. doi: 
Schoenberg R, Marks MA, Schuessler JA, et al (2009) Fe isotope systematics of coexisting amphibole and pyroxene in the alkaline igneous rock suite of the Ilímaussaq Complex, South Greenland. Chem Geol 258:65-77.

Schoenberg R, von Blanckenburg F (2006) Modes of planetary-scale Fe isotope fractionation. Earth Planet Sci Lett 252:342-359. doi: 10.1016/j.epsl.2006.09.045

Schuessler JA, Schoenberg R, Sigmarsson O (2009) Iron and lithium isotope systematics of the Hekla volcano, Iceland - Evidence for Fe isotope fractionation during magma differentiation. Chem Geol 258:78-91.

Severmann S, Johnson CM, Beard BL, et al (2004) The effect of plume processes on the Fe isotope composition of hydrothermally derived $\mathrm{Fe}$ in the deep ocean as inferred from the Rainbow vent site, Mid-Atlantic Ridge, $36^{\circ} 14^{\prime} \mathrm{N}$. Earth Planet Sci Lett 225:63-76. doi: 10.1016/j.epsl.2004.06.001

Shahar A, Elardo SM, Macris CA (2017) Equilibrium fractionation of non-traditional stable isotopes: an experimental perspective. Rev Mineral Geochemistry 82:65-83.doi: 10.2138/rmg.2017.82.3

Shahar A, Schauble EA, Caracas R, et al (2016) Pressure-dependent isotopic composition of iron alloys. Science (N.Y.) 353:580-582. doi: 10.1126/science.aad9945

Shahar A, Young ED, Manning CE (2008) Equilibrium high-temperature Fe isotope fractionation between fayalite and magnetite: An experimental calibration. Earth Planet Sci Lett 268:330-338. doi: 10.1016/j.epsl.2008.01.026

Shanks WC, Bischoff JL, Rosenbauer RJ (1981) Seawater sulfate reduction and sulfur isotope fractionation in basaltic systems: Interaction of seawater with fayalite and magnetite at 200$350^{\circ} \mathrm{C}$. Geochim Cosmochim Acta 45:1977-1995. doi: 10.1016/0016-7037(81)90054-5

Simon AC, Pettke T, Candela PA, et al (2004) Magnetite solubility and iron transport in magmatichydrothermal environments. Geochim Cosmochim Acta 68:4905-4914. doi: 10.1016/j.gca.2004.05.033

Smythe DJ, Wood BJ, Kiseeva ES (2017) The S content of silicate melts at sulfide saturation: New experiments and a model incorporating the effects of sulfide composition. Am Mineral 102:795803. doi: 10.2138/am-2017-5800CCBY

Sossi PA, Foden JD, Halverson GP (2012) Redox-controlled iron isotope fractionation during magmatic differentiation: an example from the Red Hill intrusion, S. Tasmania. Contrib to Mineral Petrol 164:757-772. doi: 10.1007/s00410-012-0769-x

Sossi PA, Halverson GP, Nebel O, Eggins SM (2015) Combined Separation of Cu, Fe and $\mathrm{Zn}$ from Rock Matrices and Improved Analytical Protocols for Stable Isotope Determination. Geostand Geoanalytical Res 39:129-149. doi: 10.1111/j.1751-908X.2014.00298.x

Sossi PA, Nebel O, Foden J (2016) Iron isotope systematics in planetary reservoirs. Earth Planet Sci Lett 452:295-308. doi: 10.1016/j.epsl.2016.07.032

Sossi PA, O'Neill HSC (2017) The effect of bonding environment on iron isotope fractionation between minerals at high temperature. Geochim Cosmochim Acta 196:121-143. doi: 10.1016/j.gca.2016.09.017

Su BX, Teng F-Z, Hu Y, et al (2015) Iron and magnesium isotope fractionation in oceanic lithosphere and sub-arc mantle: Perspectives from ophiolites. Earth Planet Sci Lett 430:523-532. doi: 10.1016/j.eps1.2015.08.020

Syverson DD, Borrok D, Seyfried WE (2013) Experimental determination of equilibrium Fe isotopic fractionation between pyrite and dissolved $\mathrm{Fe}$ under hydrothermal conditions. Geochim 
1363

1364

1365

1366

1367

1368

1369

1370

1371

1372

1373

1374

1375

1376

1377

1378

1379

1380

1381

1382

1383

1384

1385

1386

1387

1388

1389

1390

1391

1392

1393

1394

1395

1396

1397

1398

1399

1400

1401

1402

1403

1404

1405

Syverson DD, Luhmann AJ, Tan C, et al (2017) Fe isotope fractionation between chalcopyrite and dissolved Fe during hydrothermal recrystallization: An experimental study at $350{ }^{\circ} \mathrm{C}$ and 500 bars. Geochim Cosmochim Acta 200:87-109. doi: 10.1016/J.GCA.2016.12.002

Teng F-Z, Dauphas N, Helz RT (2008) Iron isotope fractionation during magmatic differentiation in Kilauea Iki lava lake. Science 320:1620-2. doi: 10.1126/science.1157166

Teng F-Z, Dauphas N, Huang S, Marty B (2013) Iron isotopic systematics of oceanic basalts. Geochim Cosmochim Acta 107:12-26.

Testemale D, Brugger J, Liu W, et al (2009) In-situ X-ray absorption study of Iron(II) speciation in brines up to supercritical conditions. Chem Geol 264:295-310. doi: 10.1016/j.chemgeo.2009.03.014

Toplis MJ (2005) The thermodynamics of iron and magnesium partitioning between olivine and liquid: criteria for assessing and predicting equilibrium in natural and experimental systems. Contrib to Mineral Petrol 149:22-39. doi: 10.1007/s00410-004-0629-4

Toplis MJ, Carroll MR (1995) An Experimental Study of the Influence of Oxygen Fugacity on Fe-Ti Oxide Stability, Phase Relations, and Mineral-Melt Equilibria in Ferro-Basaltic Systems. 36:1137-1170.

Toplis MJ, Carroll MR (1996) Differentiation of Ferro-Basaltic Magmas under Conditions Open and Closed to Oxygen : Implications for the Skaergaard Intrusion and Other Natural Systems. $37: 837-858$.

Trommsdorff V, López Sánchez-Vizcaíno V, Gómez-Pugnaire MT, Müntener O (1998) High pressure breakdown of antigorite to spinifex-textured olivine and orthopyroxene, SE Spain. Contrib to Mineral Petrol 132:139-148. doi: 10.1007/s004100050412

Turner SP, Foden JD, Morrison RS (1992) Derivation of some A-type magmas by fractionation of basaltic magma: An example from the Padthaway Ridge, South Australia. Lithos 28:151-179.

Turner SP, Williams HM, Piazolo S, et al (2018) Sub-arc xenolith Fe-Li-Pb isotopes and textures tell tales of their journey through the mantle wedge and crust. Geology 46:947-950. doi: $10.1130 / \mathrm{G} 45359.1$

Urey HC (1947) The thermodynamic properties of isotopic substances. J Chem Soc 562-581.

Urosevic M, Nebel O, Padron-Navarta JA, Rubatto D (2018) Assessment of O and Fe isotope heterogeneity in garnet from Kakanui (New Zealand) and Erongo (Namibia). Eur J Mineral. doi: 10.1029/EO060i020p00457-02

Vanpeteghem CB, Angel RJ, Ross NL, et al (2006) Al, Fe substitution in the $\mathrm{MgSiO}_{3}$ perovskite structure: A single-crystal X-ray diffraction study. Phys Earth Planet Inter 155:96-103. doi: 10.1016/J.PEPI.2005.10.003

Wallace PJ, Edmonds M (2011) The Sulfur Budget in Magmas: Evidence from Melt Inclusions, Submarine Glasses, and Volcanic Gas Emissions. Rev Mineral Geochemistry 73:215-246. doi: 10.2138/rmg.2011.73.8

Wawryk CM, Foden JD (2015) Fe-isotope fractionation in magmatic-hydrothermal mineral deposits: A case study from the Renison Sn-W deposit, Tasmania. Geochim Cosmochim Acta 150:285298. doi: 10.1016/j.gca.2014.09.044

Wawryk CM, Foden JD (2017) Iron-isotope systematics from the Batu Hijau Cu-Au deposit, Sumbawa, Indonesia. Chem Geol 466:159-172. doi: 10.1016/J.CHEMGEO.2017.06.004

Wechsler BA, Lindsley DH, Prewitt CT (1984) Crystal structure and cation distribution in 
Wechsler BA, Prewitt CT (1984) Crystal structure of ilmenite $\left(\mathrm{FeTiO}_{3}\right)$ at high temperature and at high pressure. Am Mineral 69:176-185.

Wentzcovitch RM, Justo JF, Wu Z, et al (2009) Anomalous compressibility of ferropericlase throughout the iron spin cross-over. Proc Natl Acad Sci U S A 106:8447-52. doi: 10.1073/pnas.0812150106

Weyer S, Anbar A, Brey G, et al (2005) Iron isotope fractionation during planetary differentiation. Earth Planet Sci Lett 240:251-264. doi: 10.1016/j.eps1.2005.09.023

Weyer S, Ionov DA (2007) Partial melting and melt percolation in the mantle: The message from Fe isotopes. Earth Planet Sci Lett 259:119-133. doi: 10.1016/j.eps1.2007.04.033

Wilke M (2005) Fe in magma - An overview. Ann Geophys 48:609-617.

Wilke M, Farges F, Partzsch GM, et al (2007) Speciation of Fe in silicate glasses and melts by in-situ XANES spectroscopy. Am Mineral 92:44-56. doi: 10.2138/am.2007.1976

Williams HM, Bizimis M (2014) Iron isotope tracing of mantle heterogeneity within the source regions of oceanic basalts. Earth Planet Sci Lett 404:396-407. doi: 10.1016/j.eps1.2014.07.033

Williams HM, McCammon CA, Peslier AH, et al (2004) Iron isotope fractionation and the oxygen fugacity of the mantle. Science 304:1656-9. doi: 10.1126/science.1095679

Williams HM, Nielsen SG, Renac C, et al (2009) Fractionation of oxygen and iron isotopes by partial melting processes: Implications for the interpretation of stable isotope signatures in mafic rocks. Earth Planet Sci Lett 283:156-166. doi: 10.1016/j.eps1.2009.04.011

Williams HM, Peslier AH, McCammon C, et al (2005) Systematic iron isotope variations in mantle rocks and minerals: The effects of partial melting and oxygen fugacity. Earth Planet Sci Lett 235:435-452.

Williams HM, Prytulak J, Woodhead JD, et al (2018) Interplay of crystal fractionation, sulfide saturation and oxygen fugacity on the iron isotope composition of arc lavas: An example from the Marianas. Geochim Cosmochim Acta 226:224-243. doi: 10.1016/j.gca.2018.02.008

Williams HM, Wood BJ, Wade J, et al (2012) Isotopic evidence for internal oxidation of the Earth's mantle during accretion. Earth Planet Sci Lett 321-322:54-63. doi: 10.1016/j.eps1.2011.12.030

Woodhead J, Eggins S, Gamble J (1993) High field strength and transition element systematics in island arc and back-arc basin basalts: evidence for multi-phase melt extraction and a depleted mantle wedge. Earth Planet Sci Lett 114:491-504.

Woodland AB, Kornprobst J, Wood BJ (1992) Oxygen Thermobarometry of Orogenic Lherzolite Massifs. J Petrol 33:203-230. doi: 10.1093/petrology/33.1.203

Wu CC, Mason TO (1981) Thermopower Measurement of Cation Distribution in Magnetite. J Am Ceram Soc 64:520-522. doi: 10.1111/j.1151-2916.1981.tb10317.x

Wu H, He Y, Bao L, et al (2017) Mineral composition control on inter-mineral iron isotopic fractionation in granitoids. Geochim Cosmochim Acta 198:208-217. doi: 10.1016/j.gca.2016.11.008

Xia Y, Li S, Huang F (2017) Iron and Zinc isotope fractionation during magmatism in the continental crust: Evidence from bimodal volcanic rocks from Hailar basin, NE China. Geochim Cosmochim Acta 213:35-46. doi: 10.1016/j.gca.2017.06.018

Yang H, Lin J-F, Hu MY, et al (2019) Iron isotopic fractionation in mineral phases from Earth's lower mantle: Did terrestrial magma ocean crystallization fractionate iron isotopes? Earth Planet 
Young ED, Manning CE, Schauble EA, et al (2015) High-temperature equilibrium isotope fractionation of non-traditional stable isotopes: Experiments, theory, and applications. Chem Geol 395:176-195. doi: 10.1016/j.chemgeo.2014.12.013

Young ED, Tonui E, Manning CE, et al (2009) Spinel-olivine magnesium isotope thermometry in the mantle and implications for the Mg isotopic composition of Earth. Earth Planet Sci Lett 288:524-533.

Zhang HL, Hirschmann MM, Cottrell E, Withers AC (2017) Effect of pressure on $\mathrm{Fe}^{3+} / \Sigma \mathrm{Fe}$ ratio in a mafic magma and consequences for magma ocean redox gradients. Geochim Cosmochim Acta 204:83-103. doi: 10.1016/J.GCA.2017.01.023

Zhang L, Sun W, Zhang Z, et al (2019) Iron isotopic composition of supra-subduction zone ophiolitic peridotites from northern Tibet. Geochim Cosmochim Acta 258:274-289. doi: 10.1016/J.GCA.2019.04.031

Zhao X, Zhang H, Zhu X, et al (2010) Iron isotope variations in spinel peridotite xenoliths from North China Craton: Implications for mantle metasomatism. Contrib to Mineral Petrol 160:1-14. doi: 10.1007/s00410-009-0461-y

Zhao X, Zhang H, Zhu X, et al (2012) Iron isotope evidence for multistage melt-peridotite interactions in the lithospheric mantle of eastern China. Chem Geol 292-293:127-139. doi: 10.1016/j.chemgeo.2011.11.016

Zhao X, Zhang Z, Huang S, et al (2017) Coupled extremely light $\mathrm{Ca}$ and $\mathrm{Fe}$ isotopes in peridotites. Geochim Cosmochim Acta 208:368-380. doi: 10.1016/j.gca.2017.03.024

Zhu XK, Guo Y, O'Nions RK, et al (2001) Isotopic homogeneity of iron in the early solar nebula. Nature 412:311-3. doi: 10.1038/35085525 


\section{Figure Captions}

1475 Fig. 1. After Sossi and O’Neill (2017). Dependence of the calculated force constants on the co-ordination number and oxidation state of iron. Lines of constant $\mathrm{Fe}^{3+} / \sum \mathrm{Fe}$ are drawn on in black. Effects of two common solid solutions on the force constant (magnetite-ulvöspinel and hematite-ilmenite) are shown in grey. Minerals are shown in white squares; Her $=$ Hercynite, Chr $=$ Chromite, Usp = Ulvöspinel, Mag = Magnetite, Hem = Hematite, $\mathrm{Ilm}=$ Ilmenite, Fay $=$ Fayalite, Alm $=$ Almandine .

Fig. 2. Iron-oxygen force constant in spinel group minerals (after Roskosz et al. 2015). The regression and associated uncertainty refers to Al-bearing spinels only, and the rhyolite and basalt trend are from the data of Dauphas et al. (2014). P\&M = Polyakov and Mineev 2000; $\mathrm{P}=$ Polyakov et al., 2007; $\mathrm{M}=$ Mineev et al. 2007; D = Dauphas et al. 2012.

Fig. 3. After Dauphas et al. (2014). Mean force constants of Fe-O bonds in silicate glasses for basalt (circle), andesite (square), dacite (triangle) and rhyolite (diamond) compositions as a function of their $\mathrm{Fe}^{3+} / \sum \mathrm{Fe}$ content measured by XANES. The linear trends defined by the data permit extrapolation of $\mathrm{Fe}-\mathrm{O}$ force constants to $\mathrm{Fe}^{3+} / \sum \mathrm{Fe}=1$. Uncertanties on the error envelopes are $95 \%$ confidence intervals.

Fig. 4. After Liu et al. (2017). Force constants $(\mathrm{N} / \mathrm{m})$ of iron bonds in $\mathrm{Fe}^{3+}$-free basaltic glass (black squares) with their associated $95 \%$ confidence intervals as a function of pressure $(\mathrm{GPa})$ at room temperature $(300 \mathrm{~K})$. Black lines are linear fits to the data. Also shown are iron force constants in bridgmanite (Rustad and Yin, 2009, dashed line and Shahar et al., 2016, purple square).

1490 Fig. 5. After Fujii et al. 2014. Temperature dependence of the $10^{3} \ln \beta^{56 / 54} \mathrm{Fe}$ for aqueous a) $\mathrm{Fe}^{2+}$ and b) $\mathrm{Fe}^{3+}$ species. The vertical scale factor of $b$ ) is $1.5 \times$ that of a).

1492 Fig. 6. Melting models from Sossi \& O’Neill (2017) (see eqs. 21-24). a) Variation of the fractionation factor between liquid and solid as a function of source lithology and degree of melting. Peridotites in the spinel (sp) and garnet (gt) fields show similar fractionation, whereas partial melts of eclogites (ecl) have a more pronounced enrichment in heavy isotopes. $b$ ) Variation of the fractionation factor between solid and liquid as a function of $\mathrm{Fe}^{3+} / \sum \mathrm{Fe}_{\mathrm{Melt}}$ for three difference source compositions; 'Ox' = oxidised $\left(\mathrm{Fe}^{3+} / \sum \mathrm{Fe}_{\text {Source }}=0.051\right)$, 'Int' $=$ intermediate $\left(\mathrm{Fe}^{3+} / \sum \mathrm{Fe}_{\text {Source }}=0.036\right)$, 'Red' = reduced $\left(\mathrm{Fe}^{3+} / \sum \mathrm{Fe}_{\text {Source }}=0.021\right)$. Dashed lines are fraction of melting $(F)$ contours, listed to their right. Melting of more oxidised sources is associated with greater isotopic fractionation.

1499 Fig. 7. After Sossi and O’Neill (2017). Iron isotope composition of mafic rocks (black triangle, MORB; white square, Hawai'i; grey circle, Tahiti) from the ocean basins (Teng et al., 2013), corrected to their primary magma compositions, plotted against $\mathrm{Gd} / \mathrm{Yb}_{\mathrm{N}}$. Black lines show the iron isotope compositions of melts modelled by batch melting (Eq. (21)), at melt fractions given in grey, in both the garnet (gt) and spinel (sp) fields from a primitive mantle source (grey star), and of eclogite partial melts (ec), from an N-MORB source $\left(\delta^{57} \mathrm{Fe}=+0.1 \%\right)$.

Fig. 8. After Foden et al. (2018). $\delta^{57} \mathrm{Fe}_{(\mathrm{IRMM}-14)} v s$. Slab Thermal Parameter $(\varphi) / 100 \mathrm{~km}$ for population means for each arc or arc segment. The error bars are 2SE and the $95 \%$ uncertainty envelope of the linear regression is indicated as the black curves. Value for MORB is from Teng et al. (2013).

1507 Fig. 9. After Heimann et al. 2008. An early compilation of iron isotope analyses in igneous rocks.

1508 Fig. 10. $\delta^{57} \mathrm{Fe}$ of whole rocks against their $\mathrm{Mg} \#$, characterising the change in iron isotope composition with differentiation. a) 1509 Analyses of co-genetic whole-rock samples from tholeiitic suites: green squares = Kilauea Iki (Teng et al. 2008), blue diamonds = Hekla (Schuessler et al. 2009), orange circles $=$ Red Hill (Sossi et al. 2012) display disparate behaviour depending on whether the system evolved open (Hekla) or closed (Red Hill, Kilauea Iki) to oxygen exchange (see Systems open and closed to oxygen exchange). b) Simplified versions of Figs 4 and 7 from Toplis and Carroll (1996), highlighting the contrasting 
1513 change in $f \mathrm{O}_{2}$ relative to the FMQ buffer and $\mathrm{Fe}_{2} \mathrm{O}_{3}$ (wt. \%) for conditions open and closed to oxygen exchange, respectively. 1514 These trends directly mirror those seen in a.

1515 Fig. 11. After Du et al. 2017. Compilation of Fe isotope mineral compositions in igneous rocks.

1516 Fig. 12: After Debret et al. (2016). Increase in $\delta^{56} \mathrm{Fe}$ and decrease of $\mathrm{Fe}^{3+} / \Sigma \mathrm{Fe}$ ratio in serpentinites during subduction. Bulk 1517 sample iron isotope composition versus $\mathrm{Fe}^{3+} / \Sigma \mathrm{Fe}$ in subducted Alpine lizardite (Liz-) and antigorite (Atg/Liz- and Atg-) 1518 bearing serpentinites are compared to the one of abyssal serpentinites. 


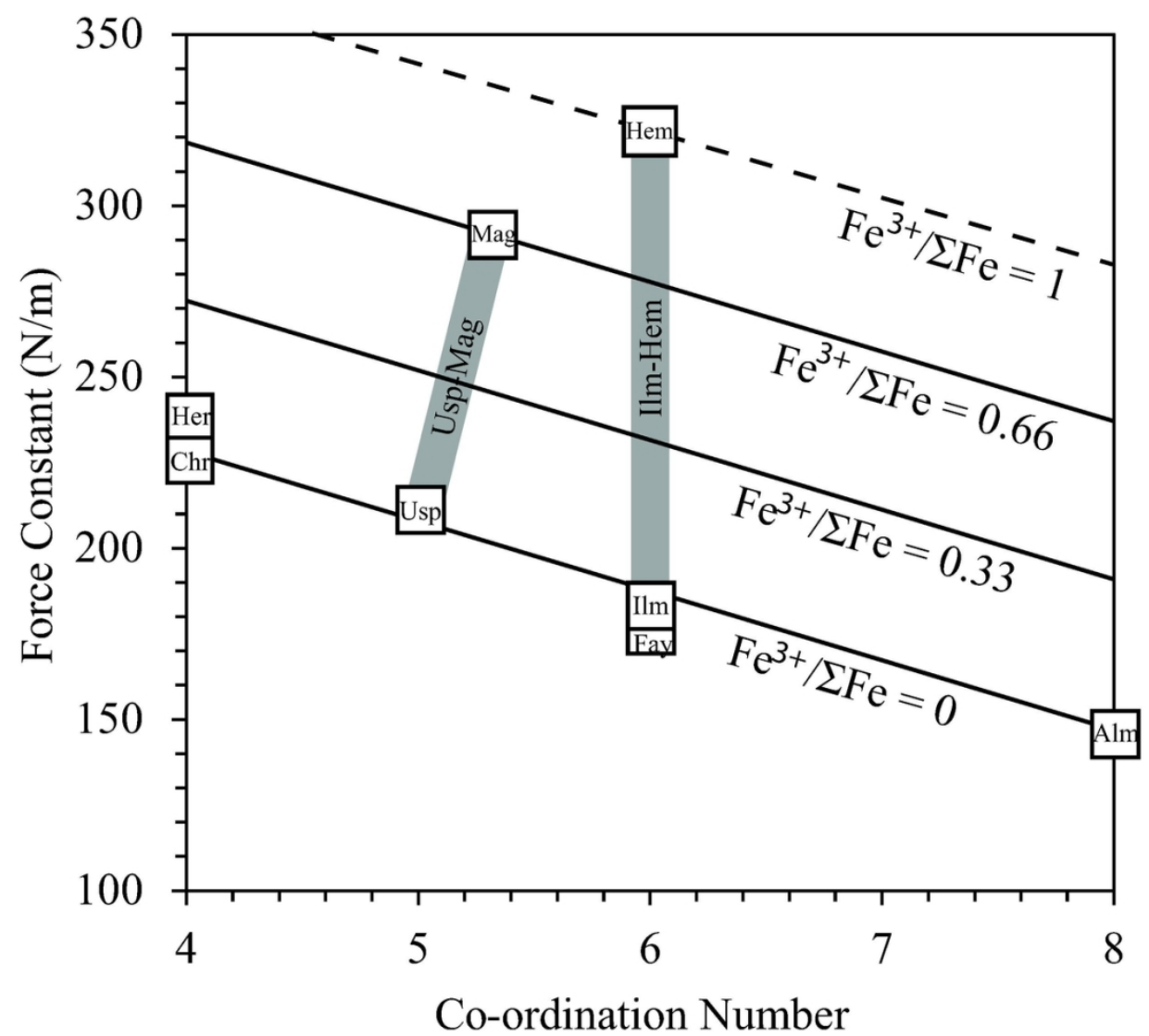

Fig. 1. After Sossi and O'Neill (2017). Dependence of the calculated force constants on the co-ordination number and oxidation state of iron. Lines of constant Fe $\mathrm{F}^{3+} / \Sigma \mathrm{Fe}$ are drawn on in black. Effects of two common solid solutions on the force constant (magnetite-ulvöspinel and hematite-ilmenite) are shown in grey. Minerals are shown in white squares; Her $=$ Hercynite, Chr $=$ Chromite, Usp $=$ Ulvöspinel, Mag $=$ Magnetite, Hem = Hematite, $\mathrm{Ilm}=$ Ilmenite, Fay = Fayalite, Alm = Almandine. 


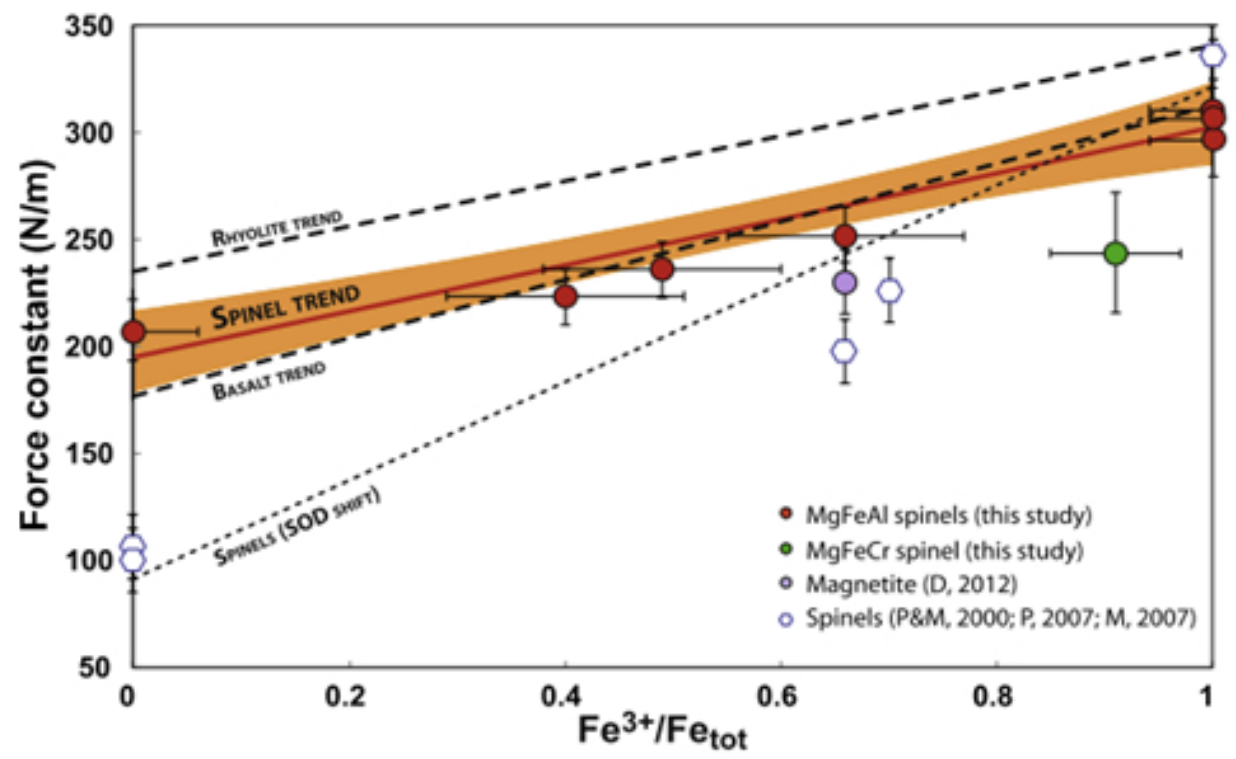

Fig. 2. Iron-oxygen force constant in spinel group minerals (after Roskosz et al. 2015). The regression and associated uncertainty refers to Al-bearing spinels only, and the rhyolite and basalt trend are from the data of Dauphas et al. (2014). P\&M = Polyakov and Mineev 2000; P = Polyakov et al., 2007; M= Mineev et al. 2007; D = Dauphas et al. 2012. 


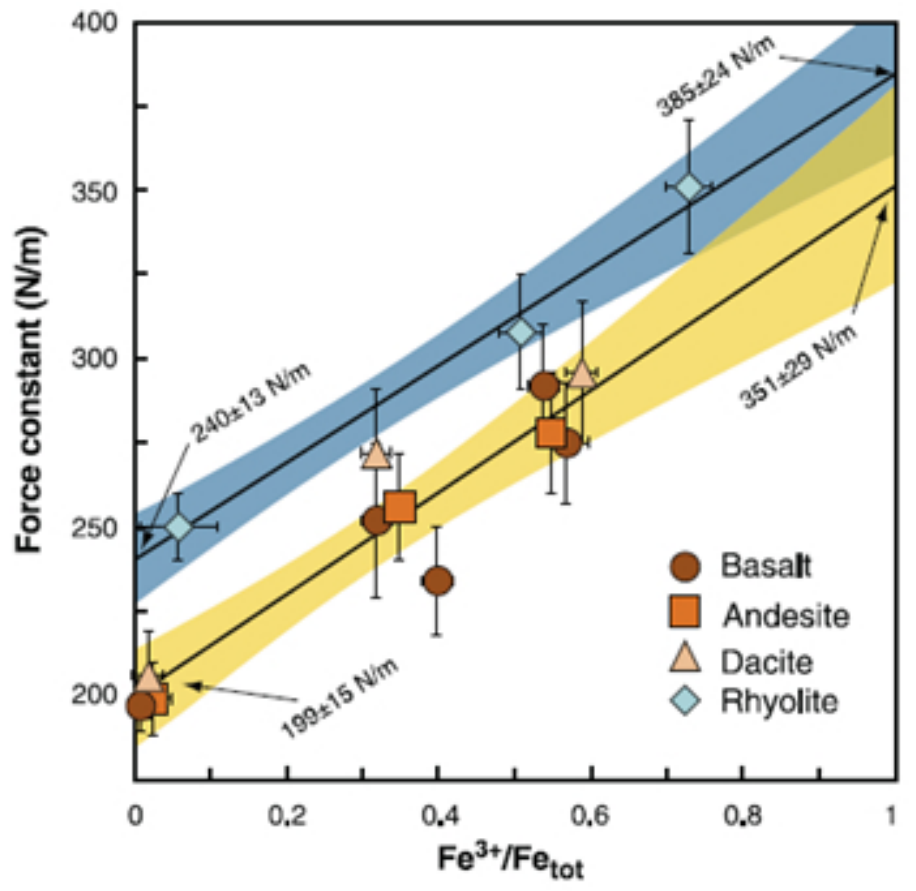

Fig. 3. After Dauphas et al. (2014). Mean force constants of Fe-O bonds in silicate glasses for basalt (circle), andesite (square), dacite (triangle) and rhyolite (diamond) compositions as a function of their Fe ${ }^{3+} / \Sigma \mathrm{Fe}$ content measured by XANES. The linear trends defined by the data permit extrapolation of Fe-O force constants to $\mathrm{Fe}^{3+} / \Sigma \mathrm{Fe}=1$. Uncertanties on the error envelopes are $95 \%$ confidence intervals. 


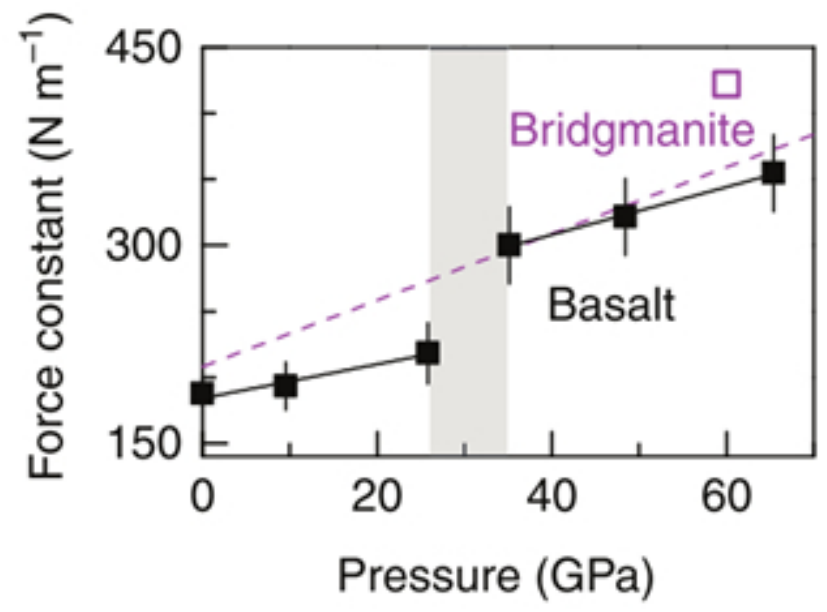

Fig. 4. After Liu et al. (2017). Force constants $(\mathrm{N} / \mathrm{m})$ of iron bonds in $\mathrm{Fe}^{3+}$-free basaltic glass (black squares) with their associated $95 \%$ confidence intervals as a function of pressure (GPa) at room temperature $(300 \mathrm{~K})$. Black lines are linear fits to the data. Also shown are iron force constants in bridgmanite (Rustad and Yin, 2009, dashed line and Shahar et al., 2016, purple square). 


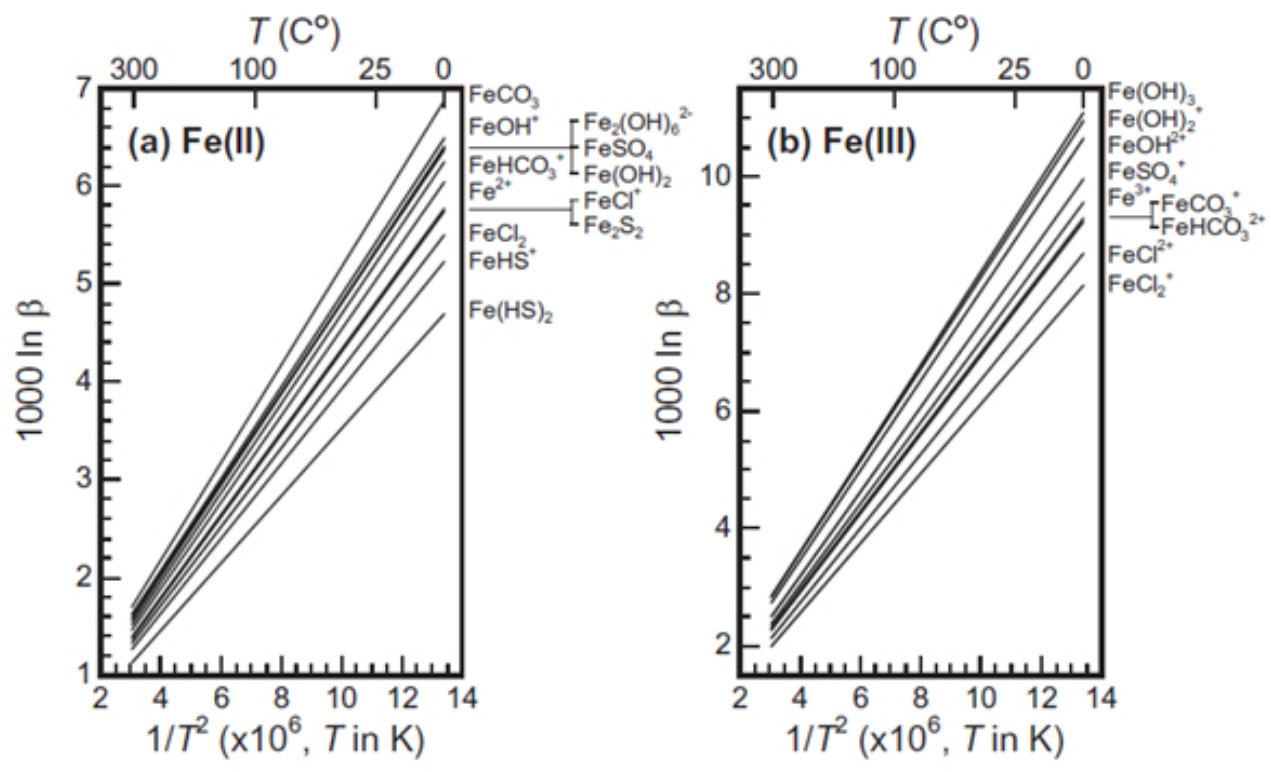

Fig. 5. After Fujii et al. 2014. Temperature dependence of the $10^{3} \ln \beta^{56 / 54} \mathrm{Fe}$ for aqueous a) $\mathrm{Fe}^{2+}$ and b) $\mathrm{Fe}^{3+}$ species. The vertical scale factor of $\mathrm{b}$ ) is $1.5 \times$ that of $\mathrm{a}$ ). 

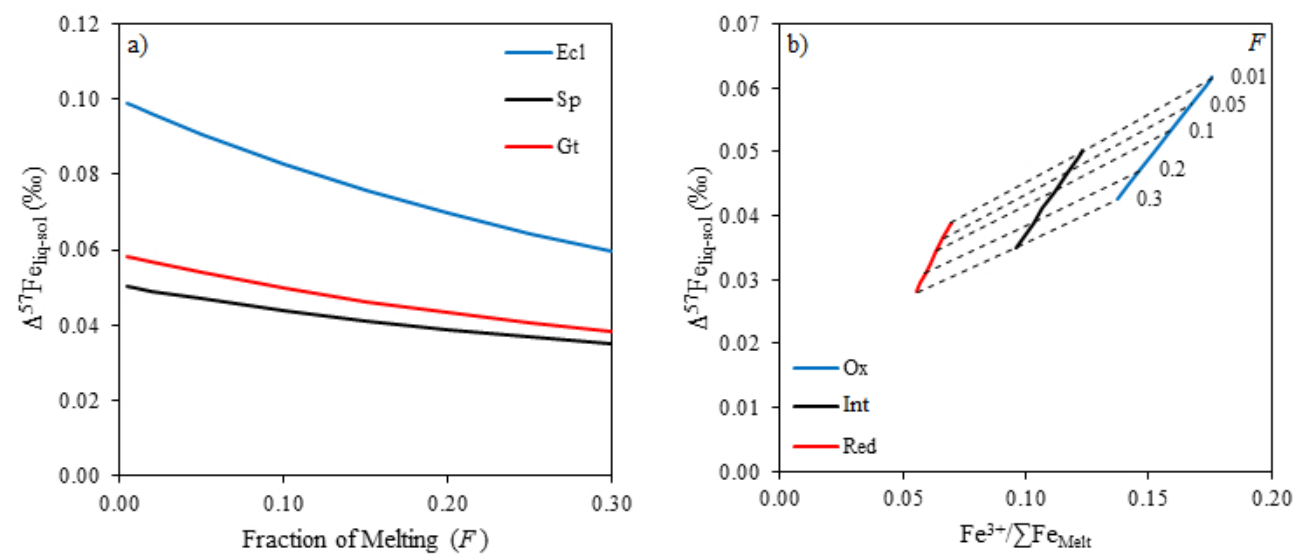

Fig. 6. Melting models from Sossi \& O'Neill (2017) (see eqs. 21-24). a) Variation of the fractionation factor between liquid and solid as a function of source lithology and degree of melting. Peridotites in the spinel (sp) and garnet (gt) fields show similar fractionation, whereas partial melts of eclogites (ecl) have a more pronounced enrichment in heavy isotopes. b) Variation of the fractionation factor between solid and liquid as a function of $\mathrm{Fe}^{3+/} \Sigma \mathrm{Fe}_{\text {Melt }}$ for three difference source compositions; ' $\mathrm{Ox}$ ' $=$ oxidised $\left(\mathrm{Fe}^{3+} / \Sigma \mathrm{Fe}_{\text {Source }}=\right.$ 0.051), 'Int' $=$ intermediate $\left(\mathrm{Fe}^{3+} / \Sigma \mathrm{Fe}_{\text {Source }}=0.036\right)$, 'Red' $=$ reduced $\left(\mathrm{Fe}^{3+} / \Sigma \mathrm{Fe}_{\text {Source }}=0.021\right)$. Dashed lines are fraction of melting $(F)$ contours, listed to their right. Melting of more oxidised sources is associated with greater isotopic fractionation. 


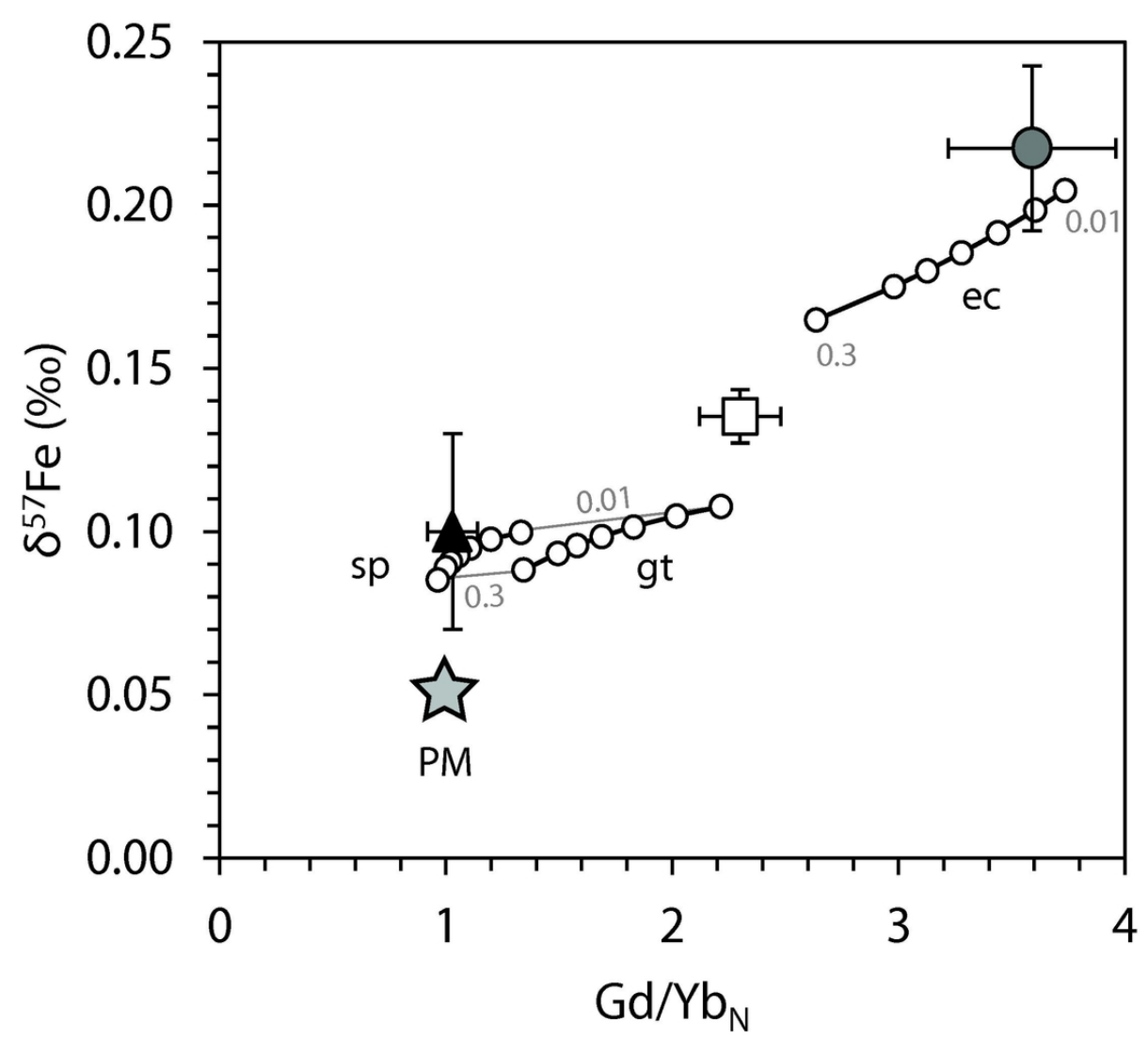

Fig. 7. After Sossi and O'Neill (2017). Iron isotope composition of mafic rocks (black triangle, MORB; white square, Hawai'i; grey circle, Tahiti) from the ocean basins (Teng et al., 2013), corrected to their primary magma compositions, plotted against $\mathrm{Gd} / \mathrm{Yb}_{\mathrm{N}}$. Black lines show the iron isotope compositions of melts modelled by batch melting (Eq. (21)), at melt fractions given in grey, in both the garnet (gt) and spinel (sp) fields from a primitive mantle source (grey star), and of eclogite partial melts (ec), from an N-MORB source $\left(\delta^{57} \mathrm{Fe}=+0.1 \%\right.$ )

$102 \times 91 \mathrm{~mm}(300 \times 300 \mathrm{DPI})$ 


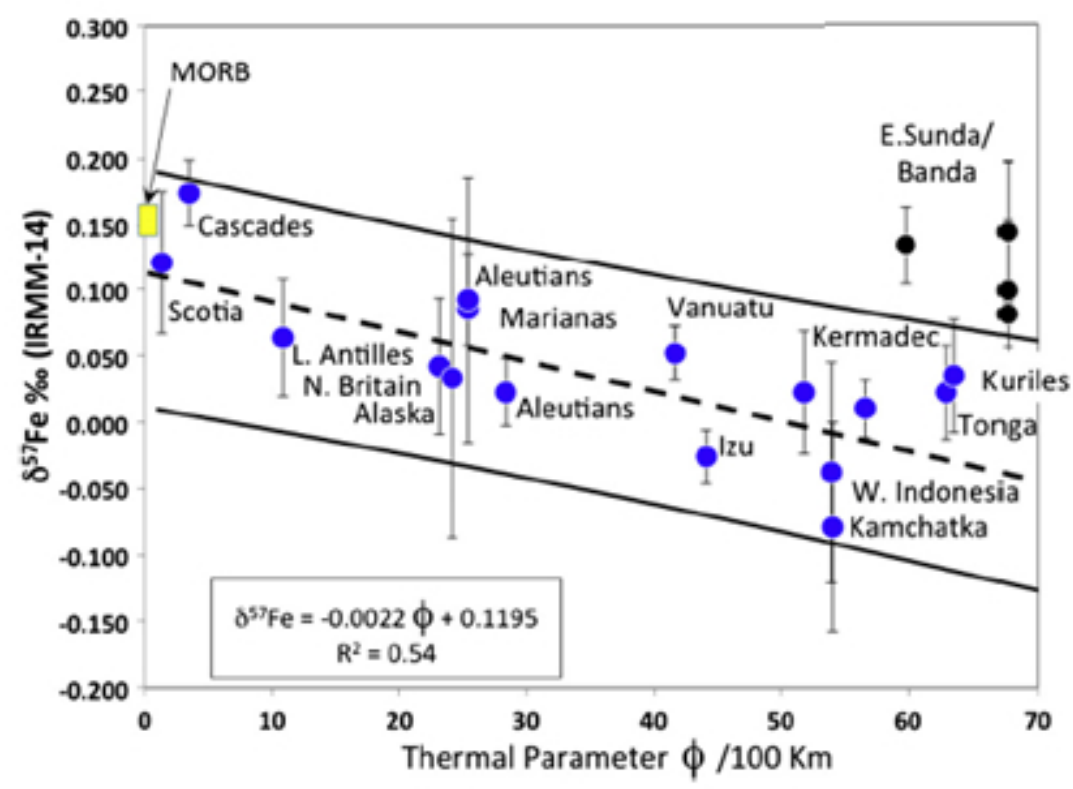

Fig. 8. After Foden et al. (2018). $\delta^{57} \mathrm{Fe}(\mathrm{IRMM}-14)$ vs. Slab Thermal Parameter $(\varphi) / 100 \mathrm{~km}$ for population means for each arc or arc segment. The error bars are 2 SE and the $95 \%$ uncertainty envelope of the linear regression is indicated as the black curves. Value for MORB is from Teng et al. (2013). 


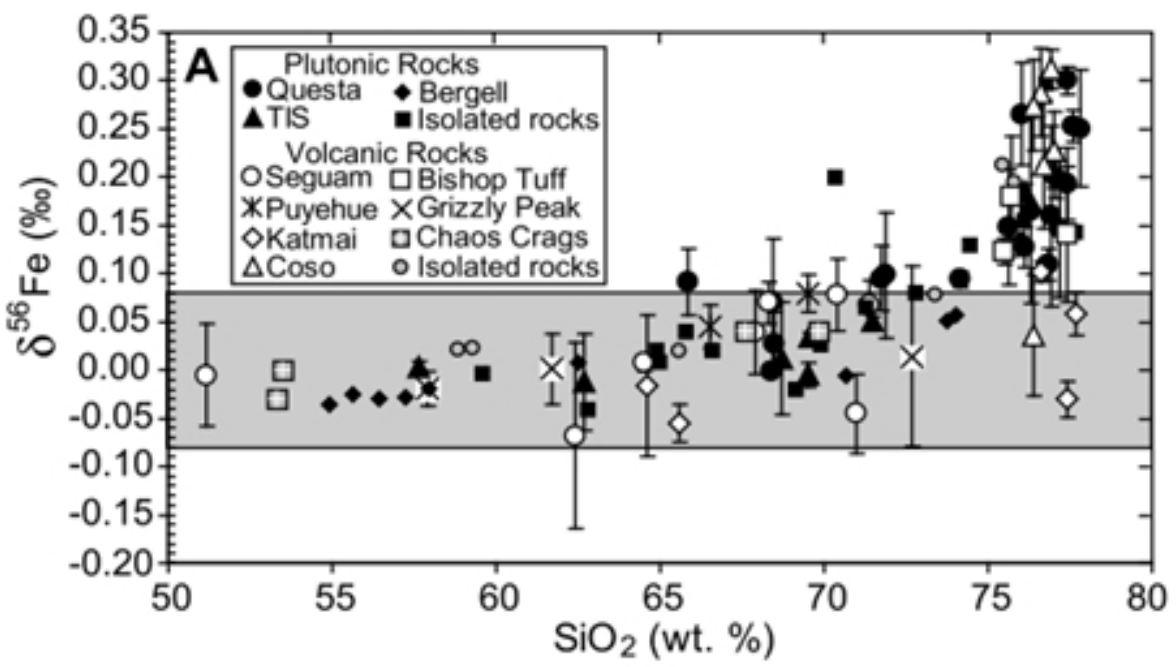

Fig. 9. After Heimann et al. 2008. An early compilation of iron isotope analyses in igneous rocks. 


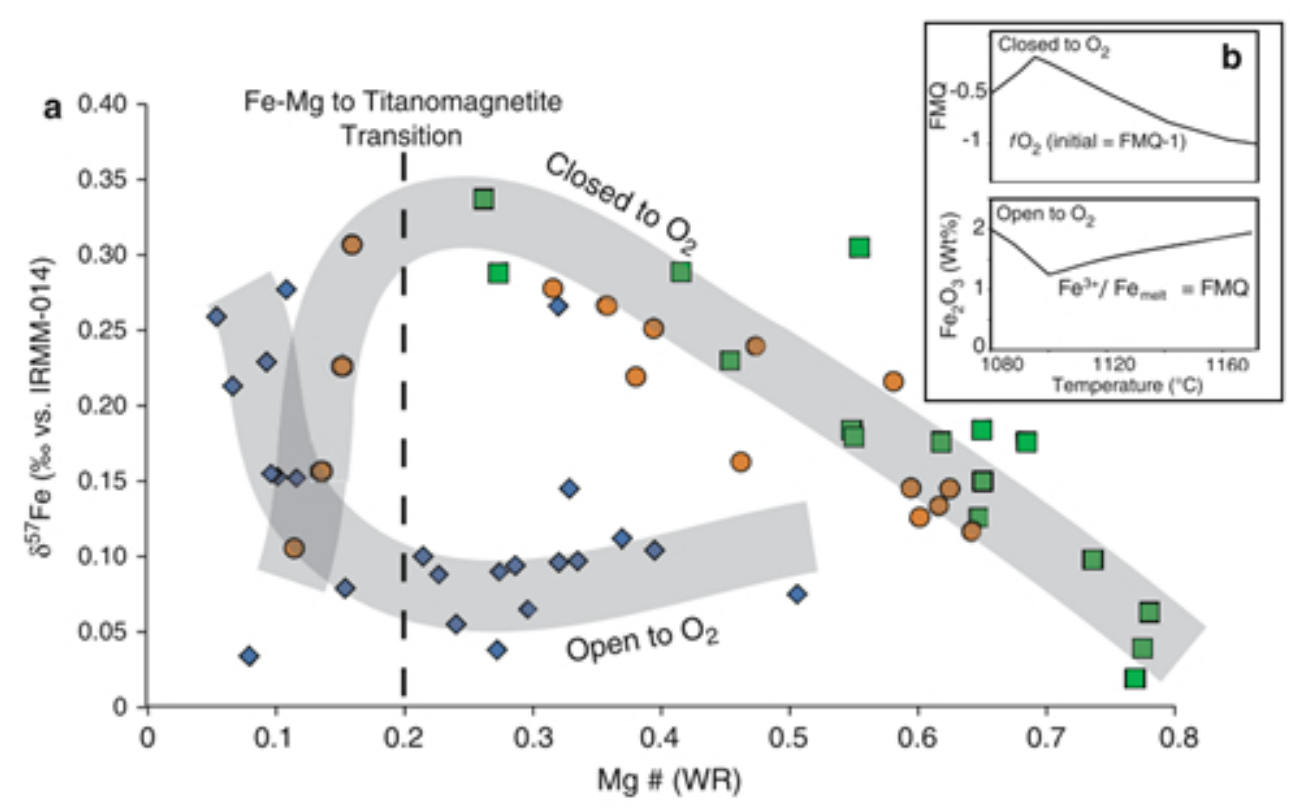

Fig. $10 . \delta^{57} \mathrm{Fe}$ of whole rocks against their $\mathrm{Mg \# ,} \mathrm{characterising} \mathrm{the} \mathrm{change} \mathrm{in} \mathrm{iron} \mathrm{isotope} \mathrm{composition} \mathrm{with}$ differentiation. a) Analyses of co-genetic whole-rock samples from tholeiitic suites: green squares = Kilauea Iki (Teng et al. 2008), blue diamonds = Hekla (Schuessler et al. 2009), orange circles = Red Hill (Sossi et al. 2012) display disparate behaviour depending on whether the system evolved open (Hekla) or closed (Red Hill, Kilauea Iki) to oxygen exchange (see Systems open and closed to oxygen exchange). b) Simplified versions of Figs 4 and 7 from Toplis and Carroll (1996), highlighting the contrasting change in $\mathrm{fO}_{2}$ relative to the $\mathrm{FMQ}$ buffer and $\mathrm{Fe}_{2} \mathrm{O}_{3}$ (wt. \%) for conditions open and closed to oxygen exchange, respectively. These trends directly mirror those seen in a. 


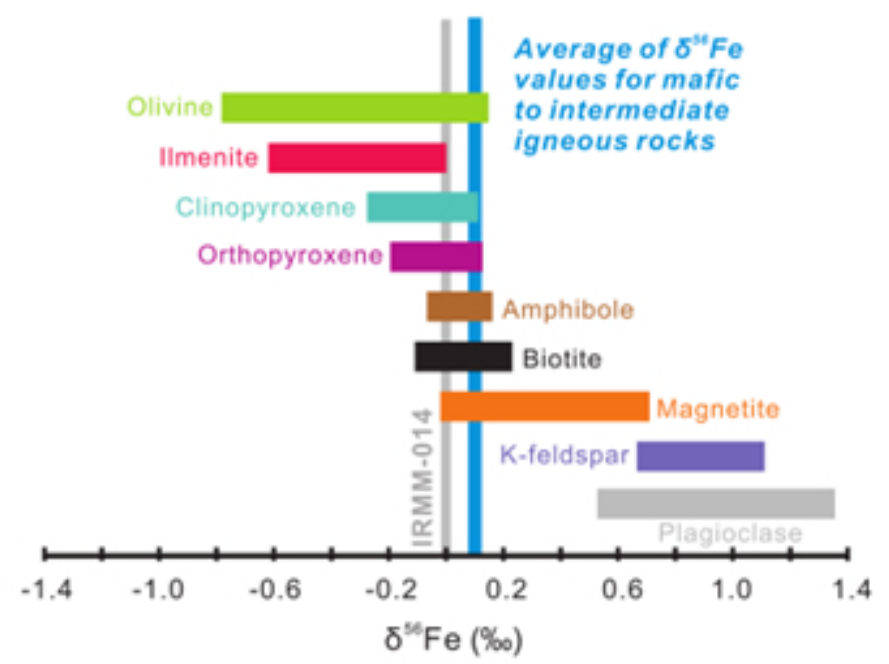

Fig. 11. After Du et al. 2017. Compilation of Fe isotope mineral compositions in igneous rocks. 


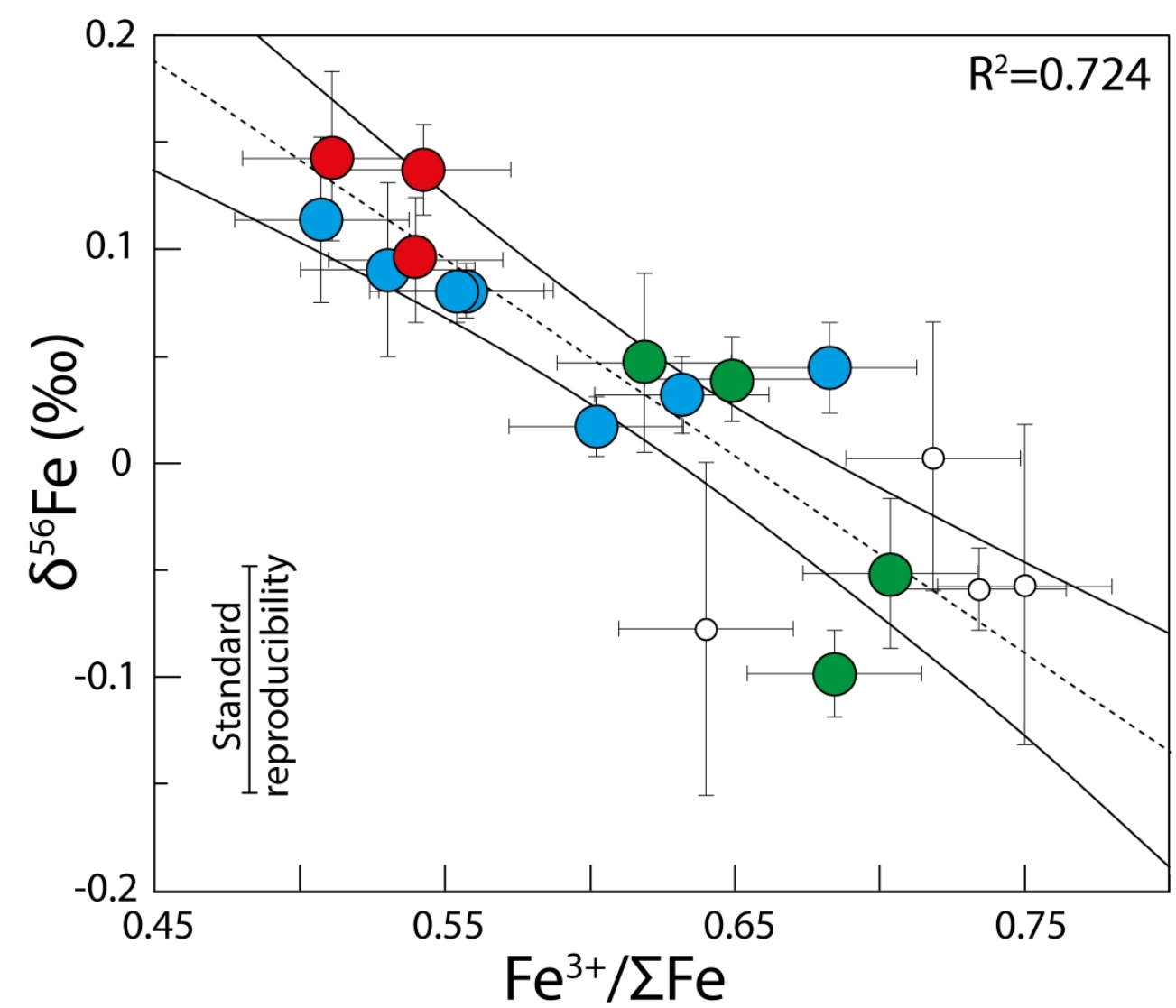

Atg-serpentinite $\bigcirc$ Atg/Liz-serpentinite $\bigcirc$ Liz-serpentinite ○ Abyssal serpentinite

Fig. 12: After Debret et al. (2016). Increase in $\delta^{56} \mathrm{Fe}$ and decrease of $\mathrm{Fe}^{3+} / \Sigma \mathrm{Fe}$ ratio in serpentinites during subduction. Bulk sample iron isotope composition versus $\mathrm{Fe}^{3+} / \Sigma \mathrm{Fe}$ in subducted Alpine lizardite (Liz-) and antigorite (Atg/Liz- and Atg-) bearing serpentinites are compared to the one of abyssal serpentinites. 